Portland State University

PDXScholar

\title{
Orwellian Socialism and the Myth of the Working Class
}

Malcolm P. Ringo IV

Portland State University

Follow this and additional works at: https://pdxscholar.library.pdx.edu/open_access_etds

Part of the Political History Commons

Let us know how access to this document benefits you.

Recommended Citation

Ringo, Malcolm P. IV, "Orwellian Socialism and the Myth of the Working Class" (1997). Dissertations and Theses. Paper 5591.

https://doi.org/10.15760/etd.7463

This Thesis is brought to you for free and open access. It has been accepted for inclusion in Dissertations and Theses by an authorized administrator of PDXScholar. Please contact us if we can make this document more accessible: pdxscholar@pdx.edu. 


\section{THESIS APPROVAL}

The abstract and thesis of Malcolm $P$. Ringo IV for the

Master of Arts degree in History

were presented February 12, 1997

and accepted by the thesis

committee and the department.

Committee Approvals:

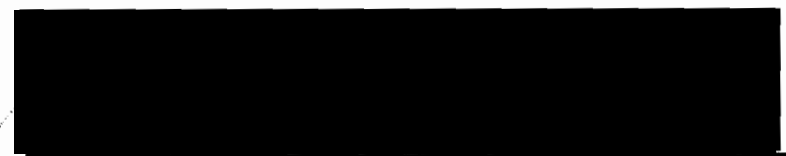

, Chair

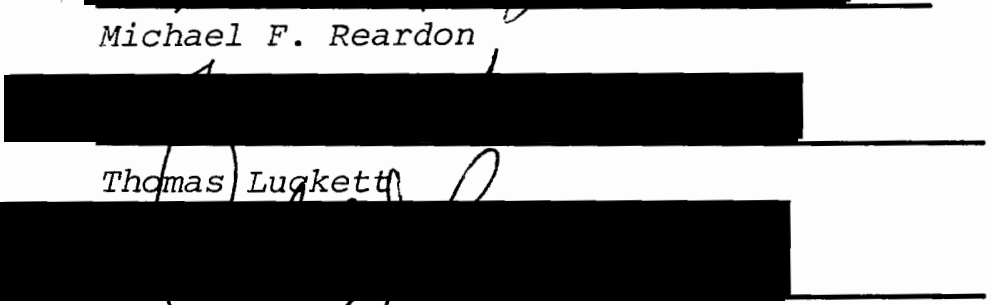

David A. Johnfon

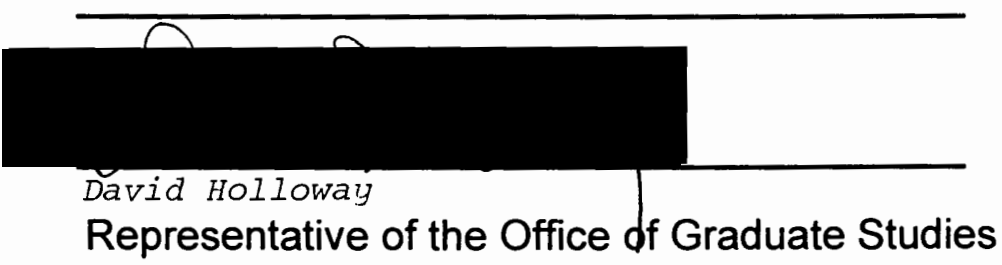

Department Approval:

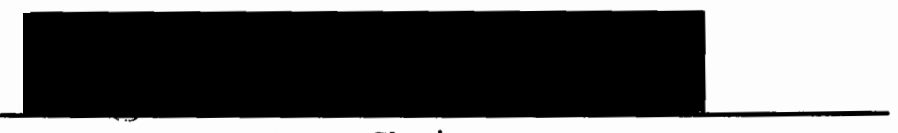

Gordon B. Dodds, Chair

Department of History

Accepted for Portland State University by the Library

by

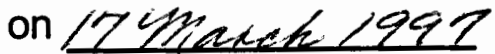




\section{ABSTRACT}

An abstract of the thesis of Malcolm P. Ringo IV for the Master of Arts in History presented February 12, 1997.

Title: Orwellian Socialism and the Myth of the Working Class

George Orwell left behind a rich body of political writings. Most scholars until now have confined research on Orwell to one of three areas: his reaction to the British class system; his criticisms of left-wing intellectuals; and the contrasting visions of the future that contended for supremacy in his consciousness. Scholars have overlooked the fact that the very foundation of Orwellian socialism rested on the creation of a political myth - the myth of the northern British working class. The northern British proletariat held specific traits, such as generosity and decency, that were created and shaped by particular socio-historical conditions. Orwell believed that these characteristics would lead the northern proletariat, who were the natural heirs to power in Britain, to revolution during World War II.

By creating the myth, Orwell contradicted his earlier writings in which he claimed that the use of political myths was inherently deceitful. 
He had always said that a successful socialist movement would replace ideological jargon, technical language and propaganda with an honest, simple and flexible blueprint of a path to socialism. He gave only vague outlines of an ideal society so that it would naturally evolve according to the specific needs of the moment.

The purpose of the present analysis is to define Orwellian socialism and then to prove that Orwell had, in fact, created a political myth. Chapter I is divided into four sections: Orwell, the Tory Anarchist; Orwell's Reaction to the British Class System; Orwell's Attacks on the Left; and Orwell and the Implementation of Democratic Socialism. Chapter II traces the evolution of these themes in his novels and documentaries. Chapter III argues that although Orwell attacked Georges Sorel for his advocacy of the myth of the general strike that would spur the French proletariat to a nationwide strike, Orwell had unknowingly created the myth of the northern British working class. 
ORWELLIAN SOCIALISM AND THE MYTH OF THE WORKING CLASS

by

MALCOLM P. RINGO IV

A thesis submitted in partial fulfillment of the requirements for the degree of

MASTER OF ARTS

in

HISTORY

Portland State University

1997 


\section{TABLE OF CONTENTS}

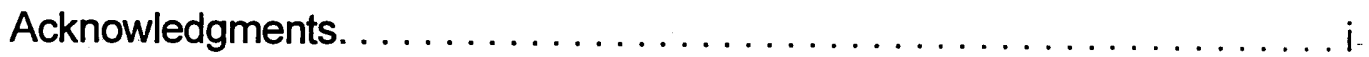

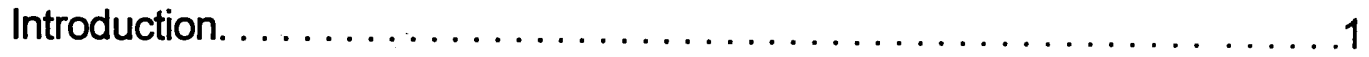

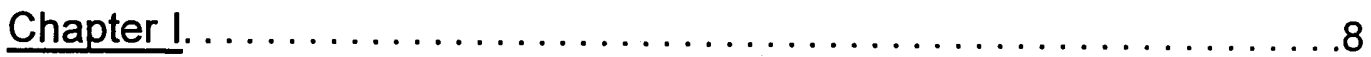

Orwell the Tory Anarchist. ..................... . 8

Orwell's Reaction to the British Class System. . . . . . . . . . . 18

Orwell's Attacks on the Left. ..................... 34

Orwell and the Implementation of Democratic Socialism. . . . . .50

Chapter II.................................61

The Socio-Literary Tradition. . .......................6.61

Reviews of: Down and Out in Paris and London. . . . . . . . . . .66

Burmese Days. . . . . . . . . . . . . . . . . .72

A Clergyman's Daughter. . . . . . . . . . . . . . . .77

Keep the Aspidistra Flying. . . . . . . . . . . . . . . . .85

The Road to Wigan Pier. . . . . . . . . . . . . . . . .90

Homage to Catalonia. . . . . . . . . . . . . . . . . . 101

Coming Up for Air. . . . . . . . . . . . . . . . . . 110

Animal Farm. ....................... . 117

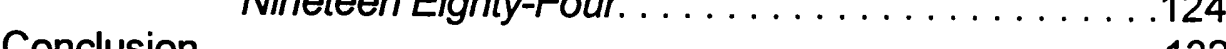

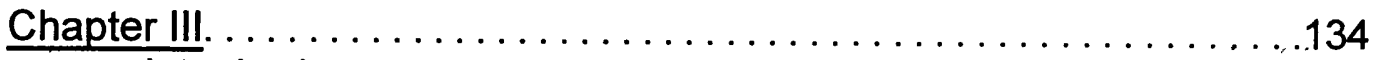

Introduction. . . . . . . . . . . . . . . . . . . . . . . . . . . 134

A Methodological Survey of Myths. . . . . . . . . . . . . . . 136

Orwell's Attacks on Sorel. ........................ . 141

Orwell and the Myth of the Working Class. . . . . . . . . . 148

Endnotes.................................... 157

Bibliography. . . . . . . . . . . . . . . . . . . . . . . . . 


\section{ACKNOWLEDGMENTS}

Several individuals deserve a special thanks for their contributions to this thesis project. Without these persons this project would not have run nearly so smoothly, or worse yet, might never have gotten off the ground. Unfortunately, I do not have the space or time to thank everyone who helped along the way but I certainly know who these persons are and, if nothing else, hold them in an elevated esteem.

To begin with I would like to thank Dr. Michael Reardon, who took time that he did not have to help me to conceptualize and structure an interesting and worthwhile topic. Next on this list falls Dr. David Robinson. Besides being a great friend, he convinced me that original contributions could still be made on the study of George Orwell. Tina Tankersley and Diane Gould - "the nuts and bolts of the Portland State History Department" - have throughout my stint at Portland State University been my sixth sense. They have gone out of their way to process my paperwork and notify me of important deadlines. Jeremy O'Leary, the Assistant Manager of the Portland State University MicroComputer Labs, has been an invaluable source. Jeremy diagnosed and fixed every "computer" problem that I brought forth (and there were many). Duyen Pham has earned a space here for never once complaining about my obsession with George 
Orwell. Her love and support kept me motivated throughout an especially gray Portland fall and winter. Lastly, I want to thank my parents who have always supported me no matter what I have done. 
Introduction

Three chapters comprise Orwellian Socialism and the Myth of the Working Class. Chapter I examines the themes commonly found when exploring the politics of Orwellian socialism. Chapter I is divided into the following four sections: Orwell, the Tory anarchist; Orwell's Reaction to the British Class System; Orwell's Attacks on the Left, and Orwell and the Implementation of Democratic Socialism. Chapter II traces the evolution of these themes in his novels and documentaries. Chapter III argues that although Orwell attacked Georges Sorel for his advocacy of the myth of the general strike that would spur the French proletariat to a nationwide strike, Orwell had, in fact, created a myth of his own, the myth of the northern British working class. This contradiction is extraordinary since Orwell had always claimed to be one of the few honest writers on the left. He had always said that a successful socialist movement must replace ideological jargon and technical language with an honest, simple and flexible blueprint of a path to socialism and what to expect in such a society. Therefore, the very fabric of "democratic socialism" (often referred to by Orwellian scholars as "Orwellian socialism") failed to measure up with the beliefs that he preached.

On several occasions during Orwell's earlier years he referred to himself as a "Tory anarchist." Scholars, such as William Laskowski, Jr., 
have referred to the term as "Tory-Radical." Understanding what Orwell meant by the term is a valuable link to comprehending the idiosyncrasies of Orwellian socialism. Tory anarchists have always valued both liberty and working-class values that include decency, generosity, equality and fraternity. According to Tory anarchists, these values were first found in early guild communities and tribal societies. By Orwell's own day, it had become painfully clear that a return to pre-industrial life would be impossible. Orwell therefore sympathized with the lot of the northern British industrial worker, and it was the untainted element in the lives of the northern British that Orwell hoped to preserve and spread to society at large.

On the surface it would seem nearly impossible to balance a deep love for liberty with generosity, fraternity and other egalitarian values. Orwell, like Tory anarchists before him, managed to do so by narrowing his definition of liberty to mean only individual rights. Orwellian socialism only extended economic liberty to small entrepreneurs, artisans and farmers, not to big business. Monopolies had to be broken, while decent wages and reasonable working conditions for the working class had to be secured. It was the legislator's duty to preserve the code of morality found in the homes of the northern British working class.

No other single issue had as much an impact on Orwell's political outlooks as that of class. Orwell's views on class gradually evolved as a 
result of his experiences. It was not until after he returned home in the early thirties from his stint as an imperial policeman that his views began to crystallize. Orwell later concluded that the relationship between the British colonists and the Burmese natives was based solely on oppression. Wherever Orwell looked throughout his life, the upper classes exploited those underneath them. Not only did he witness firsthand the discrimination of tramps and beggars in the slums of London and Paris, but he also viewed with horror the treatment of the working class in both northern Britain and in Spain. It was not that the upper classes were necessarily bad people; it was that the class system helped to mold and shape the outlooks and even the tastes and manners of each of the classes. Orwell even recalled in "Such, Such Were the Joys" being treated by his schoolmasters according to the socio-economic status of his parents. Orwell therefore regarded it as the intellectual's duty to first point out the class structure for what it was and then to change it.

He ascribed specific traits to each class. For instance, he believed that a large part of the decency, generosity and thrift of the northern British working class could be traced to socio-historical conditions found only in northern Britain, experienced only by the working class. Similar to a sociologist, he believed that under specific conditions a certain class would most likely act a certain way. Based on these sociological constructions, he predicted a working-class revolution led by the British 
lower-middle class in late 1941. Although this never happened, his hopes for the implantation of democratic socialism would rest on similar constructs for the entirety of his life.

Orwellian socialism should not be understood as a political ideology. Orwell dealt more in generalities and broad principles, claiming that to create dogma would not only make for an inflexible system but would also contradict the true nature of democracy. For Orwell no two situations were ever totally alike. Novel situations demanded original solutions. How democratic could a political orthodoxy ever hope to be? In this way Orwell should be looked upon as a practical thinker rather than an idealist.

Orwell hoped to strengthen the left wing by exposing the confining, undemocratic nature of political and religious ideologies. It should not be surprising then that Orwell saved his most fervent attacks for the Communist Party. Communist ideology denied the possibility for religious spiritualism, freedom of thought, Protestant morality and patriotism, all of which Orwell considered to be important. To worsen matters, the rhetoric of the Communist Party was highly technical, making it nearly impossible for the working class to read and understand, much less for its members to rise to positions of power inside the Party. Similarly, Orwell claimed that many Catholics who held Church offices were actually reactionaries who had no respect for individual liberties. For 
similar reasons he lambasted various other political ideologies, including the pacifists and Fabians to name a few.

After it became apparent that Orwell had miscalculated a workingclass revolution in 1941, his writings increasingly grew pessimistic. Two visions of the future competed for supremacy in his mind. The more optimistic side of Orwell still insisted the implementation of democratic socialism would occur, even though it might happen gradually, rather than overnight. In stark contrast stood the possibility of a future dominated by a totalitarian regime not unlike that found in Nineteen Eighty-Four. Orwell only warned that Britain could, under the right circumstances, resemble such a nightmarish society. He intended for Animal Farm and Nineteen Eighty-Four to act as propaganda devices to warn British society of the dangers that came with the collectivization of any society; neither was considered to be prophetic. Each reflected his love for intellectual liberty and other British traditions. Orwell wrote a number of other essays and journal articles in his latter years that speculated on the future structure of British society. He speculated that at best Britain could reasonably hope to serve as an example to the world of a democracy based on decency and liberality.

Orwell considered himself less an artist than a political writer. He intended for his longer works to be catalysts for social and political change. The themes discussed in Chapter I can be found over and over 
again in Orwell's fiction and documentaries. These themes are not static; rather, they evolved over time. Therefore, a review of his longer works is needed to trace the evolution of these themes. The majority of the commentary in Chapter II deals with the British class system and how the upper classes misused it to exploit the less fortunate. In these works, especially as time went on, Orwell increasingly sentimentalized the plight of the working-class. He also spent a considerable amount of time attacking left-wing intellectuals and the ideologies they espoused. His most pointed attacks against the Communist Party came in Animal Farm, but these attacks extended to all patrons of the left, to Labour leader and anarchist alike.

During one such episode, Orwell attacked the French syndicalist Georges Sorel for claiming that successful social and political movements would have to inspire a faith in the proletariat not unlike that found in the major religions in order for radical change to take place. Orwell attacked Sorel for several reasons. He considered the propagation of myth to be inherently deceitful. How else could a myth be transformed into action without heavy dosages of propaganda? But to term the myth of the general strike "utopian" as Orwell did was inaccurate. Ironically, even though he attacked Sorel, Orwell, himself, had created a political myth of his own - the myth of the northern British working class. Without this myth the implantation of democratic socialism, whether via social revolution or a policy of gradualism, would be impossible. In addition to idealizing the traits of the northern British working class, works such as Animal Farm and Nineteen Eighty-Four, were blatant attempts to 
alter public opinion. The turn away from realism to these more powerful genres of fiction, the fable and utopian, ratified Orwell's acceptance of Sorel's belief in the necessity of political myth. Therefore, Chapter III begins with a methodological survey of the meaning of myth; this is followed by a critique of Orwell's attacks on Sorel; and, finally, ends with a discussion of Orwell and how he, too, created a political myth. 
Chapter 1

Orwell, the Tory Anarchist

The difficulty in comprehending Orwellian socialism often arises from the failure to understand the sometimes conservative, sometimes libertarian strand of thought known as either Tory anarchism or ToryRadicalism. Each term describes those British intellectuals, including Orwell, who have fought for the preservation of liberty, as well as egalitarian working-class values. Tory anarchists do not cling to complex economic laws or abstract theories, nor do they believe that government legislation can solve all of the working class's problems. Orwell described the Tory anarchism of Jonathan Swift in "Politics vs. Literature: An Examination of Gulliver's Travels" as: "practically pessimistic," as "despising authority while disbelieving in liberty, and preserving the aristocratic outlook while seeing clearly that the existing aristocracy is degenerate and contemptible." ${ }^{1}$ To ascribe a specific agenda of beliefs to all Tory anarchists is impossible, but there are several commonalties found in the writings of Tory anarchists. They have always looked to an idealized past in an attempt to find judicious solutions to the present, which they commonly believe to be characterized by tyranny and corruption. They have commonly idealized societies where both an individual's needs and rights were honored. Tory anarchists have typically viewed war as corrupting and as a means for the strong to control the weak, yet working-class coups d'etat have often been advocated and even 
considered to be patriotic. Most, if not all, Tory-Radicals have empathized with the plight of the working class, while holding a strong aversion for government bureaucrats and powerful capitalists. Therefore, a system has to be "just so" to balance the seemingly contrary elements of independence and individuality with those of equality and fraternity. Orwellian socialism, in fact, did manage to balance the Tory anarchist agenda.

On several occasions in his earlier years, Orwell referred to himself as a Tory anarchist. ${ }^{2}$ Biographer Bernard Crick reports that Orwell described himself to The Adelphi staff in late 1930 as a Tory anarchist. Staff member and lifelong friend Richard Rees seconded Crick's account, describing him as a "Bohemian tory-anarchist" who held no real political opinions until 1936, only a love for the past and an unmatched belief in individual liberty. ${ }^{3}$ In various writings he made favorable allusions to the Young Englanders and other proponents of Tory anarchism, such as Swift, William Hazlitt, William Cobbet and Charles Dickens (Though he never called Dickens a Tory anarchist, he ascribed to him both conservative and libertarian modes of thought.).

Tory anarchism was originally used to describe a faction of the Tory Party that sided with the eccentric, often nostalgic politics of Benjamin Disraeli. The group of conservatives, nicknamed "Young England," helped Disraeli push through social reforms that benefited the poor and working class. ${ }^{4}$ The term changed somewhat over the years. Orwell regarded the early-nineteenth-century essayist, William Hazlitt, as the quintessential Tory anarchist. He distrusted all political parties, 
especially the conservative Tories, and even criticized the in some ways humane Disraeli for his promotion of imperialism. While Hazlitt wrote to protect the liberty of his countrymen, his beliefs were not without a conservative edge. He considered the past to be the touchstone to the present, for he, like most Tory anarchists, believed the present was decadent. He thus tried to reform the present with solutions based on traditional values. He described his own brand of "Toryism" - which differed considerably from what he considered to be a tyrant-filled Tory Party - as a deep concern for the individual (albeit the worker), which was not all that different from the Tory belief in individual liberty in economic matters. Unlike the Tories, he, as well as other Tory anarchists, always pushed for reforms to benefit the working class. ${ }^{5}$

In "George Orwell and the Tory-Radical Tradition," William E. Laskowski asserted that Orwell's early intellectual make-up was firmly grounded in the Tory-Radical tradition. Laskowski defined ToryRadicalism "...as an ideological division between a deep concern for the protection of the individual, and a concomitant yet often conflicting desire to improve the total well-being of the group." ${ }^{16}$ When these sometimes competing goals have conflicted, Tory-Radicals have traditionally chosen intellectual liberty over the well-being of the group, for they believed that when given freedom the working class would act with moral conviction and would not inhibit others' actions. Dickens, too, strongly believed in the importance of individual liberty while empathizing with the working class. In "Charles Dickens," Orwell says that Dickens went so far as not to condemn laissez-faire capitalism, even though he mourned the fact that 
it forced many hard working people into poverty, sickness and squalor. He only went as far as condemning those individuals who acted irresponsibly and without moral conviction. ${ }^{7}$ Orwell, too, criticized the major abusers of the system yet held the system accountable for creating such a class of oppressors. Tory Radicals have always regarded power as a corrupting agent. Therefore, their criticisms have generally been reserved for wealthy capitalists, the aristocracy and government officials. They have, to a large degree, modeled their political ethos on the behavior ever-present in working-class homes. This code based on decency and generosity can be traced back to guild communities and tribal communities, where men had seemingly practiced the mutual aid that anarchists like Mikhail Bakunin had advocated. These attributes of anarchism, along with its reliance on liberty, appealed to Orwell. He later centered democratic socialism around such a system of morals. These were given emphasis rather than economic laws or utopian visions.

Orwell found much to admire in the traditions and customs of both the working class and the lower segments of the middle class. In an introduction to Homage to Catalonia, Lionel Trilling asserted that the strain of conservative-radicalism in Orwell's intellectual outlook can be traced to a deep love of the past and the soil. Although he never mentioned Tory-Radicalism or Tory-anarchism, it is certain that he was describing traits in Orwell that could be termed as Tory anarchist. "He does not dream of a new kind of man, he is content with the old kind, and what moves him is the desire that this old kind of man should have freedom, bacon, and proper work." 8 Trilling attributed much of Orwell's 
affection for the woiking class to his stint in Burma where he saw first hand the systematic exploitation of the natives. Trilling wrongly claimed that Orwell held no sentimentality towards the working class. Orwell, like Dickens, sentimentalized the British working-class throughout his writings - most notably in The Road to Wigan Pier. Along with the working class, Trilling says that Orwell praised the lower and middle sections of the middle class. It was their "...love of personal privacy, of order, of manners, the ideal of fairness and responsibility" that he admired, while remaining critical of their tendency to separate themselves from the working class. ${ }^{9}$

Tory anarchists have not only idealized the past, but they have also looked to it to find solutions in the present. Orwell wrote on numerous occasions that the past rooted itself in the natural landscape, as well as in the manmade landscape, in old buildings and "in solid objects." Trilling connoted this love for material objects with the middle class. ${ }^{10}$ However, in all capitalistic societies all classes have looked to the accumulation of material possessions as a way of gauging quality of life. Orwell was not overly materialistic but recognized the psychological motivations behind such impulses. He understood well the workingclass tendency of prioritizing private material interests above the abstract, theoretical interests of intellectuals.

Another Orwellian theme rooted in Tory anarchism is that technology threatened to destroy the natural landscape. Crafts and trades that could be traced to feudal times were being replaced by machines, and assembly lines dehumanized the working class. By the early 
twentieth century, any right-minded person, including Orwell, would probably have concluded that technology was an intricate part of society. Orwell believed whether machinery led to a degradation or to an improvement of life depended on the motives behind its use. Orwell actually had nothing against technology (though he once said that machines stole the hands' natural functions) but did insist that the worker's life would be better if machines were taken out of the hands of the greedy capitalists and put into those of the worker. The fraternal atmosphere in Barcelona during the Spanish Civil War had shown him that workers could run a classless society. Machines placed in the right hands could potentially raise production to such a level that material wealth could be spread evenly and to higher levels than ever before to all classes. Unfortunately, as he lamented in Nineteen Eighty-Four, the upper class had resisted such a distribution because material wealth translated to political power.

The past manifested itself to Orwell in the form of childhood memories. Orwell romanticized about days spent on the "echoing greens" reading Victorian authors like H.G. Wells, who took him to futuristic paradises, and Charles Dickens, who empathized with the common person's plight. The extent that his childhood remembrances played on him can be seen in "Such, Such, Were the Joys" when he said, "[T]reacherous though memory is, it seems to me the chief means we have of discovering how a child's mind works. Only by resurrecting our own memories can we realize how incredibly distorted is the child's vision of the world." 11 Written as an adult, it was more of a literary exercise to 
convey a deep-felt point - that the private school system destroyed a child's spirit - than a factual account. "Why I Write" stands as further testimony of the primacy that Orwell attributed to his childhood. Not all of Orwell's childhood memories were as bleak as these works might lead one to think. As Crick and others have reported, Orwell led a relatively normal childhood with many ups and downs. He claimed the period was definitely influential on Orwell yet added that it could not be looked at as excessively melancholic. He says that in various writings Orwell selectively used his memory to make a point. In his last years, Orwell reminisced about joyous holidays spent with his childhood friend Jacintha Buddicom. $^{12}$

It was the Victorian era that Orwell looked to as a symbol of purity and freedom. Even imperialism, epitomized by Rudyard Kipling proclaiming it to be the "white man's burden" to civilize the natives was, on the surface, moralistic. In Orwell's day, talk of imperialism being an evangelical mission had ceased. It was simply a money-making scheme. Throughout his writings, especially in Coming Up for Air, he sentimentalized Victorian times and mourned the changes that took place in Britain after World War I. He always held that nineteenth-century America had been the pinnacle of capitalist civilization, for there was vast space, a Protestant moral code that rewarded the ambitious worker, and human freedom (in social, economical and intellectual forms), yet he readily admitted that nineteenth-century America was far from perfect, for the worker was still exploited. But it is true that he found nineteenthcentury America, as well as Britain, to be a freer time. It was before 
monopolies had taken over, which was his primary criticism of capitalism. As Orwell put it in "Inside the Whale," "[i]n mid-nineteenth-century America men felt themselves free and equal, were free and equal, so far as that is possible outside a society of pure Communism. There was poverty and there were even class-distinctions, but except for the Negroes there was no permanently submerged class."13

The Tory anarchist economic system could best be described as an attempt to be self-sufficient. It placed utmost value in productive labor (physical work that resulted in something tangible). Farmers were traditionally idealized, for they worked with the land to produce food to maintain society. Small businesses, not allowed to grow too large, were regarded as useful. The Tory-Radical economic system assumed that the individual should be left economically independent, self sufficient, and free to make a living as he or she wished. Orwell realized that big business had grown to such an extent that something radically different had to occur to free the worker. It would be impossible, he said, for the worker to regain autonomy under the existing system. For this reason he advocated a social revolution in "The Lion and the Unicorn," released in December 1940. Only with working-class control could democratic reform truly take place. Tory anarchists ideally believed that power radiated outward from the individual to the family, then to the nation, and finally to the outside world. ${ }^{14}$

Tory anarchists have commonly claimed that popular writers and politicians had a corrupting effect on the English language. Writers of this tradition: Jonathan Swift, William Cobbet and William Hazlitt, thought that 
a writer's duty was to take social injustices to the public in order to promote grass roots activism or whatever the case demanded. Each man, in his own way, was conservative in that he glorified the past but was militant, even "radical" when it came to protecting individual rights. To promote their political beliefs, they have been ever so careful to convey their messages in an honest, simple and logical manner. Tory anarchists have said that language's only purpose is to convey plain, simple and understandable messages to as many people as possible. Although metaphors and decorative adjectives were often needed to remain individualistic, more often than not, politicians and popular writers had used language to deceive and step around the "real" issues. Orwell, like many of his Tory anarchist predecessors, wrote a number of essays most notably "Politics and the English Language," which blamed intellectuals and the press for destroying the quality of the English language with haughty, poorly constructed prose that defended the flimsiest of premises (which often meant propaganda on behalf of an obscure orthodoxy). He bitterly lamented the infiltration of English by American slang and, worse, by borrowed phrases from French, Latin and Greek. He even went as far as saying in "The English People" that "language ought to be the joint creation of poets and manual workers. ${ }^{15}$ He had, in fact, always glorified the Cockney accent of the northern British working class, as well as lower-class folk songs.

Tory anarchists have traditionally been deeply patriotic, in that they have been prepared to fight for the hopes and traditions of the working class. These "conservative-radicals" regarded themselves as patriots; 
however, some, at one point or another, could be said to have promoted revolution as a vanguard for social change. Even while advocating revolution, each considered himself a patriot. In "Notes on Nationalism," Orwell explained that patriotism was an expression of love for the land and traditional ways, while nationalism was an aggressive claim to superiority over others. Therefore, like Tory anarchists before him, Orwell regarded revolution not as evil, but as, more often than not, necessary, so long as it contained the common person's will. Orwell explained this idiosyncrasy in late 1940 in "My Country Right or Left." "It [patriotism] is devotion to something that is changing but is felt to be mystically the same, like the devotion of the ex-White Bolshevik to Russia. To be loyal both to Chamberlain's England and to the England of tomorrow might seem an impossibility, if one did not know it to be an everyday phenomenon. Only revolution can save England. ${ }^{16}$ In the same year in "The Lion and the Unicorn," Orwell called for a popular revolution, believing it a necessity if England were to win the war and if decency was to be restored. In it he said that patriotism, alone, had kept the British from certain defeat. For Orwell war was justifiable only when it protected the workers' way of life and traditions, while civil war was advocated, so long as it was supported by a majority of the working class. 
Orwell's Reaction to the British Class System

Orwell had always said that he was a member of the "landless gentry class" or the "lower-upper-middle class," a twentieth-century offspring of the middle class. In truth, Orwell's father, an imperial policeman, earned a relatively good wage, comparable to other middleclass families. But the position lacked a middle-class status and, if not for Orwell's scholarships, would not have been enough to send Orwell to an expensive private school. The growth of this class can be traced to a declining British economy. By World War I the British Empire had shown signs of disintegration. England had to be ready to fight for her imperial possessions, because the once boundless third world had been all but partitioned. The British no longer had a stranglehold on the market. As a result, the income of the British middle class no longer matched its tastes and culture. Many, including Crick, think that Orwell's claims to being of this class were more or less a tool to endear himself to the working class; it showed them that not all was well with the middle class either. After returning from Burma, where he first became conscious of the relationship between the oppressed and the oppressor, Orwell consciously sought out situations that would put him in touch with the oppressed. He studied at home and abroad - first, the slums of London and Paris; then, the coal and textile industries in north England; and later, onto the Spanish Civil War, where Marxists would betray Orwell and the non-Marxist leftists' forces. These experiences, along with his earlier years spent in the British private school system and in Burma as an 
imperial policeman, allowed Orwell a first-hand view of the atrocities caused by the British class system. Orwellian socialism attempted to remove class distinctions, placing the working and lower-middle classes into power. Orwell's reaction to the class system influenced his political beliefs at least as much as any other single factor.

Time spent in the British private school system first exposed Orwell to the British class system. During World War II, Orwell would call for democratic reforms to the British educational system. He wanted it to be ridded of snobbery and based on ability. ${ }^{17}$ In Orwell's life, to get a decent education, to earn a substantial income and to possess a respectable status, depended on attending the right private school. As Crick noted, Orwell's experiences at St. Cyprian's and later at Eton proved to be valuable "hands-on" introductions to the British class system. Orwell insisted in "Such, Such Were the Joys" that he was conscious of a class difference between himself and the other boys. According to Crick, most boys at St. Cyprian's came from aristocratic or upper-middle and professional middle-class backgrounds, and that Orwell's partial scholarship must have been a financial burden on his parents. ${ }^{18}$ Yet, no records from the time indicate him to be unhappy or out of the ordinary. Crick says that he may have been modestly aware of a class distinction but contests that Orwell exaggerated the school's traumatic impact on him. However, nothing that Orwell wrote can be proved to be untrue. He most certainly encountered some (no telling how much) snobbery from the other boys, and there is no telling whether his schoolmaster maliciously reminded him that he was on scholarship to prompt him to do 
better so to bring the school fame. ${ }^{19}$ What upset him most about preparatory schools like St. Cyprian's was that they were intellectually oppressive, which others have said before. Private school must have felt extremely authoritarian to a free thinker like Orwell, and learning by rote has never appealed to such intellects. ${ }^{20}$

Orwell won a scholarship to highly-touted Eton, a public school mostly made of the very rich, the very influential and of the middle class, like Orwell, on scholarship. Orwell said in an interview towards the end of his life that the school had little influence on him, which may be true, considering that his academic performance steadily declined while at Eton. In a 1948 review of B.J.W. Hill's Eton Medley, Orwell wrote that Eton could not last in its then present form because it was an anachronism, whose purpose was to train a land owning aristocracy. It did, however, contain an atmosphere that allowed an adolescent to grow intellectually, being the foremost hotbed of liberality of all of Britain's colleges. Crick verifies Orwell's claim that a friendly rivalry existed between the boys on scholarship and the social elite. It was here that although Orwell's performance inside the classroom declined, he began writing crude poetry; reading authors such as Wells, Dickens and Bernard Shaw; and became known as a sort of Bohemian rebel rouser and cynic. ${ }^{21}$ If nothing more, his writings on St. Cyprian and Eton prove a strong aversion to authority had developed by the time he finished at Eton. He would never go to a university like most of his literary contemporaries did and he would call for educational reform throughout his life. He criticized the existing school system for helping to perpetuate class distinctions and inequality. 
How much influence these formative years played on his intellectual fabric is open to debate but an influence each school, in its own way, did have. His years spent in Burma as an imperial policeman would play an even greater role.

Following in his father's footsteps, Orwell took a job in Burma as assistant district superintendent in the Indian Imperial Police. Crick believes that Orwell was simply doing the only thing that at the time (for a university scholarship was an impossibility) seemed logical. He would dutifully follow his father's footsteps. ${ }^{22}$ Accounts such as Alok Rai's, which assert that Orwell went to Burma to reinforce his insecure position as a member of the landless gentry, should be considered purely speculative and highly unlikely. ${ }^{23} \mathrm{He}$ arrived during a period when nationalist sentiments, such as the Burmese boycott of British goods, were beginning to surface. However, there were no serious confrontations during Orwell's stint, yet an intellect such as Orwell's must have been highly sensitive to the political unrest. In the end Orwell resigned from the position, ashamed of his participation in Britain's imperial rule. He later explained his reasons for leaving, "[f]rom 1922-1927 I served with the Indian Imperial Police in Burma. I gave it up because the climate had ruined my health, partly because I had vague ideas of writing books, but mainly because I could not go on any longer serving an imperialism which I had come to regard as largely a racket." ${ }^{24}$ In 1929, two years after he returned to Europe, he wrote a few articles for a radical French journal outlining Britain's exploitation of Burma. In one he said that the British stole Burmese natural resources and labor under the pretext that they 
were racially and culturally superior to the native population. ${ }^{25}$ On another instance he said the bulk of Britain's proletariat lived not in Britain but in Africa and Asia, where the British military and the imperial police maintained rule over these weaker populations. ${ }^{26}$ Orwell did not write anything extensive about the social, political and economic injustices that Britain imposed on the Burmese until years after his departure. Burmese Days was not published until 1935 and his two essays, "A Hanging" and "Shooting an Elephant," were not published until 1931 and 1936 respectively. The lag between when these were written (and even those written for the radical French journal) and when he actually was in Burma further proves that his views gradually changed. Only a few accounts of Orwell remain and they vary; most accounts describe him as eccentric and reclusive. He would write throughout his life that his stint in Burma was the single most important reason for his change in attitude on the class issue. The relationship between the British and the Burmese demonstrated to Orwell the very same relationship that existed between the British upper and working classes. As the imperial policeman in "Shooting an Elephant" discovered, "[W]hen the white man turns tyrant it is his own freedom that he destroys." 27

From the winter of 1928 until the summer of 1931, Orwell lived in the slums of London and Paris, working menial jobs, sleeping in cheap labor houses, wearing dirty rags for clothes and, all the while, seeking inward peace for, what he viewed as, his lack of compassion for the Burmese during his stint as an imperial policeman. "His great preoccupation at this stage seems to have been to 'reclassify' himself by 
plunging from time to time into the world of tramps, doss-houses, and casual labour...He had to overcome resistance imposed on him by his own class background to physical proximity with lower-class people. ${ }^{28}$ Orwell, much like an anthropologist, recorded his experiences amongst the tramps in a systematic, unbiased way. Down and Out in Paris and London was published in 1933 in a similar, "diary-like" format. His decision to live in the slums should be interpreted as an attempt to be with another exploited population. He found in the slums a similar form of class prejudice as in Burma. Not surprisingly, his essay on Burma, "A Hanging," was written in 1931, as was "The Spike," which he later incorporated in Down and Out in Paris and London. Despite his attempt to mingle with tramps and beggars (and not the working class), Orwell never felt complete solidarity with these lowly characters. In The Road to Wigan Pier, he said it was impossible to shed his middle-class upbringing and relate fully to not only tramps and derelicts but also to the working class. Although not a socialist during this period, he was sensitive to the class issues that plagued the British home front, as well as her imperial possessions.

Orwell was commissioned by Victor Gollancz to go to northern England to study working-class attitudes in 1936. He stayed in Wigan, Barnsley and Sheffield for a total of two months. He came openly as an established writer and a journalist, unlike his time in the slums when he hid his identity. By choice he stayed most of his time in a doss-house, as if he was still down and out in Paris. On several occasions he lived for extended periods in working-class homes to gain realistic accounts of 
working-class life. He took systematic notes of the working class's wages and budgets; viewed the conditions in the coal mines and textile factories; and attended a variety of working-class political rallies sponsored by the left wing. The Road to Wigan Pier, published in 1937, showcases these experiences. It is as much a political autobiography and a study of the failure of British socialists to eliminate the fences that separated them from the working class as it is an analysis of the working class. He has often, and rightfully so, been accused of sentimentalizing the life of the working class. Crick says that Orwell left northern England believing that the working class possessed both decency and generosity "so long as a man has a job." 29 His time in the north brought him face to face with poverty, which he believed to be a necessary by-product of capitalism because it always placed production quotas and profit ahead of the worker. As a result, his dislike for big business and its use of technology grew with the trip. Although he later wrote in Homage to Catalonia that he had never before his time in Spain in 1937 been a fullfledged socialist, Orwell's writings, as well as literary contacts, reflect that he was definitely nearing an affirmation of it by the end of his stay in northern England.

Like many other leftist intellectuals, he left England for Spain in 1937 to fight the fascists. Upon arriving in revolutionary Barcelona, he found what he had failed to find in northern England, a classless society, one in which the working class was in control. Unlike the apolitical British working class, the Spanish working class understood and were willing to fight for equality and freedom. Even the militia in which Orwell served 
reaffirmed that a classless society truly was possible, for brotherhood, fraternity and, surprisingly, equality existed, even in the trenches. Orwell's provocative quote, "[q]ueer, the affection you can feel for a stranger", has to do with a brief encounter he had with an Italian volunteer whose stare adequately conveyed to him that they were both in Spain fighting for the principles of socialism. In the end he had to flee the country. The Spanish Communists, under orders from Stalin and with bourgeois support, had began purging its own left-wing allies because they were not Stalinists. Orwell would never forgive the Communists for betraying the revolution. The above experiences, from his time at St. Cyprian's to fleeing Spain from the Communists, all factored into Orwell's construction of the British class system.

Orwell divided British society into four classes and further divided these into several subdivisions. These four classes were the upper, the middle (made of the upper-middle and lower-upper middle), the lowermiddle and the working. The upper class consisted of the aristocrats and the wealthy. As he pointed out in "The English People," remnants of feudalism persisted in the upper class in the forms of hereditary aristocracy, the monarchy and the House of Lords. The aristocracy had appeared to be on the decline in the nineteenth century yet it managed to avert total loss of power by intermarrying with the bourgeoisie. The aristocracy gained money to finance an expensive culture, while merchants and manufacturers gained status. Out of this combination was born the "country gentleman." A sophisticated high culture, most noticeable in manners and accents, separated the upper from the lower 
classes. To delineate from age-old custom meant to risk the advantage of class. Members of the upper class had little sympathy for the lower classes and believed it was their right to have the same privileges that their ancestors had had. Orwell viewed them as greedy and corrupted, though not particularly evil or immoral. After all, they were patriots who had repeatedly risked their lives for Britain. However, they were unteachable patriots who would never abdicate power or enact progressive legislation. As Orwell scoffed, "[o]nly when their money and power are gone will the younger among them begin to grasp what century they are living in." ${ }^{31}$ Their decline showed through in their inability to rule during World War II, when they continually allowed private interests to take precedence over an efficient war effort. Orwell believed the decline had begun long before the war's outbreak. It could be seen when the ruling class helped Spain become fascist in 1936 and when it facilitated the sale of arms to Italy in 1939. He believed the ruling class - both the wealthy capitalists and aristocrats - were being made obsolete by managers and technicians, as James Burnham had first wrote in The Managerial Revolution. With no real understanding of the processes of capitalism, the upper class provided no useful function. The ruling class had ignored the real societal trends and failed to adapt with the times. Richard Voorhees believes this "deliberate stupidity" had been responsible for driving the better workers off the land, the ossification of the public schools and Britain's inability to organize a constructive war effort at the beginning of every war since the 1850 s. Private profit again had prevented a quick mobilization during World War II. ${ }^{32}$ 
Orwell viewed the middle class as the most diverse class of all classes. He saw its members as benefactors of the system, who were not immoral, and perhaps even decent (though the upper strands were as unteachable as the upper class), yet who were ignorant. He considered himself a member of the middle class - albeit an eccentric stratum of it. He claimed that in the twentieth century the upper-middle class had splintered into two groups - the upper-middle class, whose habits, pretensions and lifestyle shaded into that of the upper class and who consisted of the military, professional and official classes, and the "lowerupper middle class." He considered himself to be a part of the latter, which had slipped economically between the wars. Crick defined it as being "the upper-middle class short of money, not really hard up, no discomfort, but not able from their own resources to play the full role expected of them by themselves and others, both from the education they received and the status they still enjoyed." ${ }^{\text {"33 }}$ As a result, they became acutely aware of the possibility of poverty and the classes below them the working and the lower-middle classes - that were economically at a level were they might soon be. Many from this stratum turned this revelation into an aversion for the working class. Except for a small minority of the middle class, middle-class incomes had steadily fallen during the twentieth century. The income of the former "middle section" of the middle class had slipped to a level very close to that of the working class. Like the lower-upper middle class who still clung to the culture of the upper class but who earned a middle-class wage, a good part of the 
lower-middle class held tightly to middle- and upper-class values yet earned a working-class income.

Borrowing from James Burnham's apocalyptic vision, Orwell believed that if a socialist revolution was to take place it would probably have to be led or, at least, supported by the part of the lower-middle class consisting of technicians, business executives and managers, bureaucrats, soldiers and other specialists, who, with proper prodding by intellectuals, would realize that economically they had more in common with the working class than the middle class. It was this class that had the power to change the system since it, in many ways, controlled the means of production. Since the construction of this class was a relatively new phenomenon, its members were not nearly so affected by the cultures and traditions of the British class system. It would not be hard to convince the lower-middle class of the importance of radical change either. The lower-middle class watched as wealthy capitalists who owned larger businesses sat idle year round. Members of this class had made the upper class a functionless class. ${ }^{34}$ All that socialist intellectuals had to do was remove negative stigmas from the cause and in a logical manner show democratic socialism to be both just and economically beneficial. Otherwise, the lower-middle class would side with the upper classes as usual. Orwell described the outlines of this process. "It [the lower-middle] will not set up any explicit class dictatorship. It will group itself round the old Labour Party and its mass of following will be in the trade unions, but it will draw into it most of the middle class and many of the younger sons of the bourgeoisie. Most of 
its directing brains will come from the new indeterminate class of skilled workers, technical experts, airmen, scientists, architects and journalists, the people who feel at home in the radio and ferro-concrete age." ${ }^{35}$

Orwell disagreed with Burnham - who claimed the lower-middle class would set up a totalitarian oligarchy - about what type of government these so-called "managers" would set up. Why now would decent human beings lust for power, and how could this be inferred since the lowermiddle class had never possessed power throughout human history? In short, Orwell attempted to tear down the protective screen that separated the lower-middle class from the oppressed. "His aim was to make the retreat into pseudostupidity, the innocence of ignorance, an impossible alternative and to force such people to make a choice - either to support oppression once it had been exposed, or to begin to transform the unjust world they had finally come to understand." ${ }^{136}$ Works such as Coming Up for Air were addressed to this class.

Orwellian socialism attempted to put the working class, along with the lower-middle class, in charge. In "The Lion and the Unicorn," he made it explicit that democratic socialism would raise the status of the working class to that of the ruling class. His visit in 1936 to northern England proved to him that the British working class possessed specific traits that would one day (after much grooming from intellectuals) allow it to rise to power. Overall, he considered its members decent and virtuous but often illogical due to a lack of education. The average Englishman was usually old-fashioned, subconsciously patriotic, gentle and antimilitaristic. The working class also had a great respect for laws and 
government institutions and believed in individual liberty and equality by law. The working class was also apt to be stubborn, hypocritical and subject to snobbery. Sporting events and gambling took precedence over more creative or constructive endeavors. Throughout his life Orwell underestimated how slow to change and conservative the working class was. It had always been last to change, which, in some ways, had its benefits. Unlike the other learned classes, psychological and sociological explanations of the universe had not yet outmoded the Christian God. Most lived ordinary lives, attaching great importance to traditional Protestant principles of hard work and sacrifice. Orwell has been accused over and over of sentimentalizing and over-simplifying working-class life. The tenants of democratic socialism were based on what he considered to be the inherent tendencies of the working class. He thought that its non-revolutionary attitude could be linked to a lack of education, which would have provided the working class with political connections and access to the media, and to the inability of left-wing intellectuals to offer a simple platform for the working class to follow. Although members of the working class had never owned enough money to be corrupted, they were hedonistic at heart, and rightly so, he contended. In The Road to Wigan Pier, he wrote that their bellies came before their souls. Their main concern was feeding their families, not theoretical interpretations of Marxism, because only with careful budgeting did they have enough for life's basics. In this way they differed from those in the London and Paris slums, who did not even have enough to purchase life's essentials. The psychological effects of unemployment on 
the working class were worse than for a tramp. When a family man could no longer provide for his family, he had to rely on the dole, which symbolized to him a loss of autonomy. ${ }^{37}$ Yet, they continued to support bourgeois democracy, more specifically, the Labour Party, that supposedly had their interests at heart. No other class had worked so hard, yet had been rewarded so little by the capitalist machine. Even still, during World War II they were patriots, which touched Orwell enough into changing his anti-war stance. He later wrote off the change in attitude as a dream that resulted directly from the long drilling in patriotism that he, like most members of the middle class, went through as a youth.

His criticisms of the class system and imperialism were only part of a complex critique of capitalism, which changed throughout World War II to fit specific historical circumstances. He viewed capitalism as an inefficient system that bred greed in the upper classes and inequality among the masses. The average worker in northern England could work a full week and still only have enough for necessities, while the upper class had relatively few worries. The worker's future did not appear to be improving, for great monopolies were on the rise, replacing small businesses, making the worker's voice even harder to hear. For example, he noted with horror in The Road to Wigan Pier the backwards system of compensation for miners in the north. The system put the miner in a passive, humiliating role, offering neither permanent solutions nor just compensation for serious injuries. ${ }^{38}$ Although he never adopted capitalism as his political system of choice, his attitude toward it changed by mid-war. In "George Orwell's Second Thoughts on Capitalism," Arthur 
Eckstein says that Orwell had become pessimistic about the prospects of implementing democratic socialism by mid-1941. In his 21 May 1941 lecture, "Literature and Totalitarianism," Orwell claimed that capitalism was historically doomed to be succeeded by collectivized economies. He believed that collectivization could under the right circumstances lead to a totalitarian regime, as it had in the Soviet Union and Germany, which would put an end to intellectual liberty. He had never before linked the evaporation of economic liberty with that of other liberties, yet as Eckstein readily asserted, Orwell had always linked the preservation of "liberalChristian culture" with that of intellectual liberty. ${ }^{39}$ For the remainder of the war Orwell linked intellectual liberty with not only Protestant culture but also with economic freedom. Orwell was not the first to claim such a link. After all, the rise of capitalist civilization in northern European closely followed that of Protestantism. Therefore, Orwell did not introduce in the broadcast a wholly new belief, but a variant of an old belief. By this date in the war, he certainly had reason to doubt whether his call in "The Lion and the Unicorn" for a social revolution would ever be answered. He grudgingly, for the time being, had to place hope in the benevolence of the British ruling class. Therefore, his wartime support of the British government and capitalism was that of a pragmatist and a patriot who hoped to raise the morale of his countrymen. He attempted to give them reason - the preservation of intellectual liberty as well as traditional values and customs - to fight. Only with a British victory would democratic socialism have enough time to be sold to the lower classes and left-wing intellectuals. This lecture was a warning (much like in Nineteen Eighty- 
Four) of what could happen if the British lost the war. Orwell's criticisms of capitalism remained largely in tact.

To better understand his feelings on capitalism, it should not be forgotten that he had always sentimentalized the nineteenth century, when liberal-Christian culture and small capitalists flourished, before the rise of the great monopolies. Once he realized that the working class lacked the education and political consciousness to take part in a revolution, he became more supportive of capitalism (and with it the fight against the Nazis). It was not as though his criticisms of capitalism ever changed. Although he fully admitted that capitalism (and technology) had spread wealth farther down the social scale than was ever believed possible, he believed that democratic socialism could, in the long run, maximize production and labor. To preserve capitalism after the war would be ridiculous, he believed, for the British economy, like the rest of the world, was in the process of being collectivized. He could only hope to save democratic processes. Although his writings on collectivization become more and more pessimistic in the last stages of his life, he never gave up hope that in Britain democratic socialism would eventually prevail. His pessimistic writings were intellectual devices aimed at shocking the public out of its sleep. Hope did still lie with the proletariat, as he said in Nineteen Eighty-Four. In short, during the war he felt it his patriotic duty to defend capitalism, for at least it safeguarded intellectual liberty and the writer's voice. After the war it was his duty to alert the public of the dangers implicit in collectivization. 
Onwell's Attacks on the Left

Orwell attacked other left-wing intellectuals largely because he considered the rigid dogmas of their political and religious ideologies to be artificially constructed and contrary to freedom of thought. Orwell believed the future could never be known, while many political and religious ideologies (or "orthodoxies," as he often called them) implied a predestined picture of the future. Orthodoxies offered uncompromising, absolute solutions to history, which Orwell considered to be highly subjective and individualized. To make the situation worse, the technical, highly arbitrary nature of most political and religious orthodoxies necessitated intellectuals to translate doctrine to the undereducated working classes. Orwell considered most intellectuals to be elitist and even dishonest if the situation demanded it. The zeal that upholders of orthodoxies ascribed to their beliefs could be dangerous. In Spain the Communists rationalized murder under the pretense of ideology, while during World War II British pacifists refused to fight on moral grounds, even though a German victory, Orwell insisted, would mean the end to intellectual freedom and any semblance of equality. Not all of Orwell's criticisms of orthodoxies were confined to the left wing. For instance, he continually attacked Catholic clergy and intellectuals who by the twentieth century largely believed Church teachings to be little more than myth. Acting as if these myths were truths kept them in powerful positions. Orwell claimed that a large percentage of Catholic intellectuals, clergy and upper-class supporters were upholders of reactionary causes and 
therefore viciously attacked them during the Second World War. For Catholic intellectuals such as G.K. Chesterton, traditional Christian spiritualism had been transformed into a political ideology. Communists denied the existence of God, claiming there to be no need for a God in the communist state. Even socialists, such as H.G. Wells, found no need for God in his technological utopia. Everywhere Orwell turned nations were sacrificing their freedom of thought - which he connoted with Protestant morality and working-class traditions - for totalitarian doctrines. Leaders such as Hitler, Franco, Mussolini and Stalin, justified horrific acts under the pretense of ideology. In turn they were worshipped not unlike deities. Orthodoxies contrasted sharply with democratic socialism, which purposely lacked rigid dogmas and merely promised intellectual freedom in the form of Christian morality and traditional working-class values.

Orthodoxies in Britain, especially on the left, had, by and large, failed to gain the working classes' support because they had taken too low a view of the working class and had failed to speak to it in its own language. Orwell attacked intellectuals for their pompous, exclusionary attitude on numerous occasions, most thoroughly in The Road to Wigan Pier and "Propaganda and Demotic Speech." In "Politics and the English Language," he said a large part of the problem lied in the content of their message. "In our time, political speech and writing are largely the defense of the indefensible. Things like the continuance of British rule in India, the Russian purges and deportations, the dropping of the atom bombs on Japan, can indeed be defended, but only by arguments which do not square with the professed aims of political parties. Thus political 
language has to consist largely of euphemism, question-begging and sheer cloudy vagueness." 40 To understand the technical jargon of most ideologies the working class had to be educated, which they were not. Orwell believed intellectuals wrote in such a manner to preclude the working class from positions of power. In "Lion and the Unicorn," he says that the working class was patriotic and morally sound but not logical. ${ }^{41}$ They could never understand the fine print of ideology. To his credit most of his writings, especially his journalism but even his novels, were on a level that the working class could easily understand and find interesting. He believed that socialist intellectuals must, if they hoped to achieve a judicious type of socialism, both spell out the road to socialism and lay out the type of society they hoped to create in an understandable way. His criticisms of left-wing intellectuals were not to damage the socialist movement but were, what he considered to be, constructive, meant to strengthen the left. What follows are his attitudes toward a few of the orthodoxies that he examined extensively.

Orwell's most high-pitched attacks were on the Soviet Communists. In Spain they had betrayed the popular revolution by using bourgeois support to eliminate all other left-wing factions. At least as bad, they had deliberately lied about the true nature of events in Spain. The left-wing press in Britain did not want to know the truth about Spain and accepted Soviet accounts as fact. Reviewers of Homage to Catalonia said Orwell's account of the Spanish Civil War was inaccurate and even dishonest. Later, these same left-wing elements attempted to blockade the publishing of Animal Farm because of its anti-Soviet content. Not only 
did the Soviets deliberately lie about the past but they also denied that virtue could exist in tradition, or, rather, before the Russian revolution. Communist ideology denied the possibility for religious spiritualism, freedom of thought, morality and even patriotism. Lenin and Stalin had deceitfully altered ideology to fit the Party's needs and to strengthen the government's control over the people. Soviet Communism had grown less democratic and more totalitarian over the years. For example, Marx had been able to appreciate literature for art's sake, regardless of its political sway, while the writers' role in the Soviet state was solely to reverberate Party line. ${ }^{42}$ To delineate from it was blasphemy. A popular revolution had never come as Marx had predicted. Instead, a group of elites, the Bolsheviks, had forcefully imposed their will on the masses. This reflected their Jack of faith in the proletariat to initiate a revolution. What Orwell saw as especially disturbing was the revival of bourgeois habits and privileges in post-revolutionary Russia. ${ }^{43}$ A new form of privilege had emerged, and with it a new elite class of Party bureaucrats. Orwell thought that Marxist-Leninist teachings were outdated. Marx had lived in the nineteenth century and had underestimated capitalism's ability to adapt and reform to changing times; moreover, he had not foreseen the rise of the lower-middle class. Marx and Lenin had only seen the middle class as agents of the bourgeoisie, not as potential supporters of the proletariat. ${ }^{44}$ In truth, capitalism, with the aid of technology, was able to spread wealth further down the social latter than was ever thought possible. Marx, Lenin and Stalin had all wrongly concluded that economic factors were the sole determinants of human behavior and historical 
events. Marx had failed to understand the psychological needs of the people and the ruling class, who in the Soviet Union had perverted many of his teachings.

Orwell attacked British intellectuals in the thirties who looked to the Soviet state for inspiration. The "Russophiles," as he referred to them, glorified the Soviet state in order to satisfy a deeper psychological need the lust for power. This obsession with power made them unpatriotic and loyal to a group that had often disregarded the truth and humane considerations. For instance, their coverage and view of events in Spain had differed considerably from what Orwell reported. They had justified murder and betrayal of the revolution as necessary to the cause, for human history, they believed, was determined by force alone. ${ }^{45} \mathrm{He}$ attacked them for continually changing their views to meet the incongruent, ever-changing Soviet foreign policy. ${ }^{46}$ Orwell argued that Stalinist Russia was not all that different from Nazi Germany. Both were totalitarian machines controlled by a dictator and a mass party. He insisted that communists worldwide wrongly considered racial pride, leader worship and love of war as primitive emotions, even anachronisms, even though Stalin, himself, had used such propaganda devices to bolster support. ${ }^{47}$ Hitler, too, had capitalized on the basic psychological needs of the German populace. The British intelligentsia, like their Soviet counterparts, had too low a view of human nature. They, like the Soviets, believed an elite class was to ignite the revolution. Further forming an obstacle between the proletariat and themselves, their political rhetoric failed to meet the needs of the working class. 
One particular group of British Communist writers that included W.H. Auden and Stephen Spender, a group which Orwell continually criticized, came to be known as the "London elite." John Rodden contends that these writers did not originally begin their careers as political writers but were thrown into such careers only after the existing social structure failed to absorb them into traditional occupations of the powerful and elite, which could largely be blamed on the worldwide depression of the thirties. ${ }^{48}$ Instead, they were forced to take jobs as journalists, publishers, schoolmasters and private tutors. Conditions did not appear any better around the world; capitalism seemed to be failing everywhere. The Soviet state had a romantic quality about it, which was verified by the accounts of the Webb's and others who went to Moscow. Rodden says that the single most important reason for their turn to politics was the rise of Hitler. ${ }^{49}$ Orwell contends in "Inside the Whale" that these disillusioned writers turned to Soviet Communism because it offered what they could not find elsewhere. "Here was a church, an army, an orthodoxy, a discipline. Here was a Fatherland and - at any rate since 1935 or thereabouts - a Fuehrer. All the loyalties and superstitions that the intellect had seemingly banished could come rushing back under the thinnest of disguises. "Patriotism, religion, empire, military glory - all in one word, Russia. Father, king leader, hero, saviour - all in one word, Stalin. ${ }^{150}$ Orwell differed from his adversaries in several important ways. He was a few years older and had come from a lower social background than the London elite, who for the most part had come from upper-middle class and upper-class backgrounds. His time in Burma had distanced 
him from the prosperous twenties and the political events that had given rise to radicalism in the thirties. A sentimentalist and stuck in Burma, Orwell's literary tastes remained a generation behind with Dickens and Wells. He was therefore distanced from the political scene and immune to the cult of Moscow.

His loathing for orthodoxy extended to religious groups as well. He claimed that the upper crust of the Catholic Church and Catholic intellectuals were mainly comprised of reactionary elements. Orwell viewed the Catholic Church as an elitist organization with a hierarchical bureaucracy of clergy who preserved Church teachings but who did not necessarily follow or believe in them. Steinhoff said that these doctrines, even that of salvation, became little more than "myths" to intellectuals and clergy alike. ${ }^{51}$ Rees seconded this account, claiming that Orwell thought the clergy did not share or understand the common man's traditional tastes. ${ }^{52}$ Orwell said in an article for the Partisan Review in late 1941 that Catholic intellectuals and upper-class Catholics would side with Hitler against Stalin if given a chance. He said in 1945 in "Antisemitism in Britain" that well-known Catholic intellectuals, including Chesterton, were anti-Semitic. These Catholics stood opposed to democracy in England and supported right-wingers like Mussolini and Franco and were as a rule biased against Protestant countries. ${ }^{53}$ In 1945 in "Notes on Nationalism," Orwell claimed "...antisemitism comes more naturally to people of Conservative tendency, who suspect the Jews of weakening national morale and diluting the national culture. Neo-Tories and political Catholics are always liable to succumb to antisemitism, at least 
intermittently. ${ }^{154} \mathrm{He}$ further argued that British Catholics had years ago transferred nationalistic sentiments for the Motherland to the Catholic Church and to countries like France where Catholicism predominated; similarly, many British left-wingers looked to Moscow for inspiration. ${ }^{55}$ In short, political Catholics were against freedom of thought and possessed many of the same characteristics that Orwell disliked in Marxist intellectuals, and they did so under the assumption that they were imposing a necessary and beneficial order. Orwell did, however, support Protestant Christianity. Unlike the Catholicism, it nurtured freedom of thought, individuality and democracy. Moreover, it preserved traditional morals, which he believed to be deeply entrenched in working-class culture and fundamental to democratic socialism.

His quarrel with pacifist intellectuals intensified during World War II. Before and for a short while during the war, he protested with the pacifists that it was an imperialistic war: The Independent Labour Party (ILP) had split away from the Labour Party in the late thirties over this very issue. Orwell says that he joined it because it was the only major political party in Britain to oppose the war on moralistic grounds. At the time he considered the pacifists high-minded in their cause, but praise turned to criticism in 1939 the night before the Russo-German Pact was announced when Orwell changed his stance on the war and renounced his membership in the ILP. ${ }^{56}$ To understand his change of opinion towards the pacifists, it is necessary to see why Orwell, himself, had swayed to a pro-war stance. His reasoning went as follows: since a majority of the British people - especially the working class but including 
all classes - were willing to put their lives on the line, it would be unpatriotic to stand opposed to the majority. Even more instrumental in his criticism of the pacifists was his belief that rule under Nazi Germany would be worse than British capitalism, which suddenly was not all bad, for at least it preserved intellectual liberty. His most one-sided attacks came in "The Lion and the Unicorn" when he stereotyped pacifism as a "psychological current" (and not a political movement) that appealed to the sheltered. In some cases it culminated in an admiration for the power possessed by the Nazis. ${ }^{57}$ He reasoned that most pacifists opposed the war yet had never tried to alter the society that had caused it in the first place. He claimed that the ramifications of their arguments - a lowering of morale on the home front - always outweighed the original intent of pacifism, which thus made the movement immoral. Where were the cries against imperialistic militarism before the war, or against the Soviets for defending themselves during the war, he combated? The pacifists, like the rest of Britain, had benefited materially from imperialism. British society, materially secure and away from real turmoil, had been a breeding ground for pacifism. ${ }^{58}$ By 1945 with British victory a certainty, he admitted that many pacifists truly were humanitarians or members of obscure religious sects; however, he stubbornly maintained that a minority of pacifists had to be pro-Fascist. How else could their unpatriotic behavior in the face of such an evil be explained $?^{59}$

He praised, extensively in Homage to Catalonia, certain aspects of anarchism. It especially appealed to his deep love of freedom, but he considered its aims impractical. Orwell first came into contact with 
anarchists while in Spain. Many of his comrades in P.O.U.M. - a leftist workers' party - were closely allied with the anarchists. Orwell respected the anarchists for several reasons. Firstly, they stood opposed to the Communists, though they were willing to fight with them against Franco. They were the first group to warn of the potential dangers of a centralized state. Secondly, they had a strong aversion to organized government and religion. Thirdly, they thought that public opinion should determine punishments for criminals. Lastly, they called for an end to industrialization in favor of a return to village life. ${ }^{60}$ Rees said that Orwell saw first hand in places such as Catalonia and Barcelona how anarchistic principles - those of liberty and freedom - had raised public spirit. These principles had been substituted for religious spirituality, mainly because the corruption of the Catholic Church at the time was widespread. ${ }^{61} \mathrm{He}$ also, until the early part of World War II, accepted the anarchist principle that war and social revolution (the creation of a classless society) would most likely run concurrently, which sharply contrasted with the Communists' military strategy. Yet his criticisms were deep, he felt that a return to the agrarian past, to primitivism, was impossible. Industrialization could not be stopped. He believed the working class had come to expect a certain standard of living that anarchism denied. Only a planned, centralized economy that preserved democratic processes could bring a comfortable, enlightened existence. Orwell deduced in a critique of Part IV of Gulliver's Travels that the Houyhnhnms had reached the highest stage of totalitarian organization. "This illustrates very well the totalitarian tendency which is implicit in the 
anarchist or pacifist vision of society. In a society in which there is no law, and in theory no compulsion, the only arbiter of behaviour is public opinion. But public opinion, because of the tremendous urge to conformity in gregarious animals, is less tolerant than any system of law." 62

Orwell found inspiration in various utopian writings yet found them to be impractical. Utopian writers, as a rule, were unrealistic, far too caught up in describing the perfect society and not nearly practical enough to talk about the path to such a society. The fundamental concepts underlying utopian visions were unrealistic. For instance, unlike utopians' Oscar Wilde and William Morris, Orwell believed that the complete abolition of class was an impossibility, although outward, visible privileges could, to a large degree, be eliminated; a classless society could only be worked towards. However, Orwell admitted that the concept had proved valuable until the era in which he wrote. He claimed in Homage to Catalonia that a majority of people attracted to socialism were so because it implied a classless society. ${ }^{63}$ He mourned with Wilde and Morris the arrival of mass culture and the subsequent decline in high culture, but these were small prices to pay in comparison to what technology, if placed in the right hands, could bring. He had also disagreed with the anarchists on the issue of rejecting technology in favor of primitivism. Yet, unlike Wells, Orwell did not expect technology to solve all of the world's problems. While he thought the utopians were unwise to give precise accounts of the future, he found Marx's interpretation of the future to be overly vague. History really could begin after the overthrow of 
the old order, but Marx had left a little too much to the victor's imagination, which was, in fact, why it had been so easy for Lenin and Stalin to reinterpret (and often with horrifying results) Marxian doctrine. Marx had erred by not giving a more detailed description of Marxian society after the revolution. To worsen matters, Marx had mistakenly given too meticulous of an account of the means to revolution (hence the synonym "scientific socialism"). Therefore, Marx had overcompensated for what the utopians lacked and vice versa. Orwell attempted to define the tactics and ideals of democratic socialism in a simple, straightforward manner by stealing bits and pieces from both the utopian and Marxian traditions. He knew that such a strategy was essential if he hoped to attract a large following and avoid oligarchy as had happened in the Soviet Union.

Orwell wrote extensively about Wells. Wells, an eccentric Fabian, differed from his brethren in that he dreamed of a technological paradise. Orwell continually criticized the unilateral world state envisioned by Wells. Orwell claimed in "Wells, Hitler and the World State" that Wells continually put forth the same idea. "On the one side science, order, progress, internationalism, aeroplanes, steel, concrete, hygiene: on the other side war, nationalism, religion, monarchy, peasants, Greek professors, poets, horses. History as he sees it is a series of victories won by the scientific man over the romantic man." ${ }^{64}$ Orwell agreed that science would probably eventually win out but he was not nearly so optimistic that it would do so in the near future. Wells had underestimated Hitler, written him off as an anachronism who was so caught up in the past that he was not to be feared. Orwell reminded Wells that Germany was the most 
technologically advanced country in the world. "Much of what Wells has imagined and worked for is physically there in Nazi Germany. The order, the planning, the State encouragement of science, the steel, the concrete, the aeroplanes, are all there, but all in the service of ideas appropriate to the Stone Age. Science is fighting on the side of superstition. ${ }^{65}$ Even if the Wellsian paradise was ever reached, it would not be without dangers, because it naively relied on the benevolent action of those in power, which increasingly looked doubtful with the rise of Hitler and Stalin. Wells, he contended, failed to account for the irrational side of human behavior. However, Orwell's criticism of Well's optimism was unfair in that it did not take into account Well's later pessimistic writings. Orwell's criticism of Wells overlapped with his criticism of the Fabians. Orwell believed that Wells and the Fabians limited the possibility of socialism by not advocating revolution as a means for social transformation. Reform could only take place through gradualism, social planning, technological advances and administrative efficiency. What was worse was that these changes were to be imposed from the top down, products of intellectual contemplation and devoid of working-class involvement. "Orwell disliked the curiously administrative form of socialism which the Fabian-trained leaders of the Labour Party had evolved. The planned society was too often taken as the equivalent of the classless one. The mentality was fundamentally bureaucratic, the root emotion being not so much hatred of privilege as dislike of inefficiency and chaos." ${ }^{66}$ Orwell found such elitism despicable, contrary to the true nature of socialist democracy. 
Over and over Orwell criticized the Labour Party for several reasons. Because the Labour Party was run by trade unions, it was devoted solely to raising wages and improving working conditions, which meant that working-class wages depended heavily on the prosperity of British capitalism both on the home front and abroad. Consequently, the Labour Party quietly supported British imperialistic endeavors, while espousing the anti-imperialistic rhetoric common to socialism. But Orwell did not suggest for the Labour Party to hand its imperial possessions independence because other imperialistic nations would quickly swallow them up, impose an even harsher rule than Britain had enforced and cause a needless drop in the British standard of living. Orwell said in "The Lion and the Unicorn" and maintained until his death that Labour politicians should develop a "positive imperial policy" that aimed at changing the Empire into a federation of socialistic states, "like a looser and freer version of the Union of Soviet Republics." ${ }^{67}$ It is true that Labour leaders were "out of touch" with their constituents and had not lived up to their promises, yet they were not totally to blame for taking such a moderate line. Labour politicians had no outside support in key positions, such as inside the military, Colonial Services or the Home Civil Service. To carry out its promises might have caused a revolt, Orwell claimed. However, shortsighted Labour strategies were mostly to blame for such lackluster results. The Party had also been damaged during the twenties and thirties by communists and other left-wing radicals inside the Party. These factions had been chiefly responsible for alienating the middle classes from socialism. ${ }^{68}$ After World War II, Orwell said the 
Labour Party had dropped all gestures and pretenses to being a socialist party. He claimed that if the Labour Party had been a socialist party that it would have eliminated public schools, all titles and the House of Lords. Each of which was an outward manifestation of inequality. The reforms carried through by the inaugural Labour government after the war did not go very much further than a Conservative government would have. In 1944 in "The English People," he said a trend had begun in recent times and probably would continue in the future. The two major political parties in Britain were increasingly resembling one another, voicing only a moderate line of reform far from socialism yet too liberal to be of semblance to nineteenth-century conservatism: Economies around the world, he claimed, were being planned and during the war it was believed national survival rested on stopping class warfare. ${ }^{69}$ However, only for brief periods would Orwell stand opposed to the Labour Party. He grudgingly supported it until his death, claiming it his patriotic duty to support the same party that the working class did. But he never considered it a movement run by the people; instead, it was run "for" the people by middle-class intellectuals.

Orwell was not the only British socialist to be disappointed by Labour policy. Sidney Webb, who had been mainly responsible for the Labour Party platform accepted in 1918, also wrote extensively about how the Party had not kept a socialistic line. Webb, a longtime member of the Fabian Society, lamented the failure of the Labour Party to achieve his socialistic aims, which included public ownership over crucial sectors of the economy, a greater amount of economic equality and educational 
reforms along democratic lines. Labour leaders never advertised the need for public ownership because of the negative stigma placed on socialistic principles; instead, they "...placed primary emphasis on the need to tax surplus wealth for purposes of social welfare. ${ }^{70}$ According to Pierson, the Labour Party never adopted any of Webb's socialistic measures largely because disunity within the party produced different factions of thought. Perhaps even more crucial to the Labour movement's failure were the reactionary tendencies that could be found in the typical trade union leader. By the early thirties, Webb had lost all hopes in a policy of gradualism. ${ }^{71} \mathrm{He}$, too, asked how a socialist party could support imperialism when it relied on the exploitation of foreign labor. Socialism at its very core stressed international equality, he contended. 
Orwell and the Implementation of Democratic Socialism

Many critics have claimed that at his death Orwell did not give the implantation of democratic socialism any real hope. These critics wrongly base such assertions on misinterpretations of his later writings. Orwell never intended for his writings to be interpreted in such a pessimistic way; he did, however, fear the inevitable death of capitalism could lead to a totalitarian state. His darkest writings, Nineteen Eighty-Four and Animal Farm, should be interpreted, as Orwell had hoped them to be, as warnings of what could happen as states collectivized. He had hoped these writings would shock the public enough to make them conscious of the hurdles that lay ahead. Either intellectuals and the masses learned to arm themselves against the dangers implicit in collectivization, or totalitarianism, not unlike in the Soviet Union or Nazi Germany, would occur in Britain. The motive of these darker writings is unveiled when they are placed along side his essays and other journalism. Although he had reservations and fears about collectivization, his faith in the lower classes never wavered. It would now take a little longer than he had earlier expected for the lower classes and intellectuals to adopt the tenants of democratic socialism. To best understand his complex political outlooks, it is necessary to view the entirely different scenarios that he believed were vying for supremacy in the future.

His forecast for the future rested on character traits he assigned to the various classes. In "The Lion and the Unicorn," Orwell misgauged many of the working and lower-middle classes' character traits. Perhaps 
his experiences in Spain with the anarchists and other revolutionary factions had given him false premonitions about the nature of revolution. He was right in thinking that the working class was patriotic and willing to suffer for a just cause, for they fought bravely throughout the war. In the end, he believed, the burden fell on socialist intellectuals like himself those wanting to preserve freedom of thought and democratic processes. They were to alert the working and middle classes of the inevitability of collectivization and its possible pitfalls. In "The Lion and the Unicorn," he claimed that winning over the lower-middle class to democratic socialism could only happen by appealing to their sense of patriotism. "These people [the lower-middle class] are quite indispensable, because they include most of the technical experts...The only approach to them is through their patriotism. An intelligent Socialist movement will use their patriotism, instead of merely insulting it, as hitherto." ${ }^{72} \mathrm{He}$ even suggested a simple, straightforward plan for socialist intellectuals to present to the lower-middle and working classes. It included: a nationalization of major industries and land; a limitation of incomes; a more democratic educational system; immediate Dominion status for India, with power to succeed once the war was over; representation in British government by "coloured peoples"; and an alliance with China and other victims of the Axis. ${ }^{73}$ Furthermore, he proposed eliminating the House of Lords and other outward class distinctions. The plan made little headway with left-wingers in Britain. They were either hopeless victims to orthodoxy or too moderate. Part of the problem was that socialist intellectuals, including those in the Labour Party, misunderstood the true 
nature of the lower classes and concentrated propaganda on economic matters rather than the psychological. ${ }^{74}$ In "The English People," written in May 1944 but not published until August 1947, Orwell admitted that he had underestimated the strength of patriotism in the lower classes. He said that even during low points in the war national solidarity was stronger than class antagonism, which made revolution an impossibility. ${ }^{75} \mathrm{He}$ concluded that a British revolution was not morally possible because the classes were too much alike. Furthermore, Britain "was too small, too highly organized, too dependent on imported food. Civil war in England would mean starvation or conquest by some foreign power, or both". ${ }^{76}$ Though left of center, the lower classes were more moderate than he had estimated. His unheard call for a social revolution during World War II proved to him what he had said before, that members of the British working class were illogical, anti-militaristic, and lacked a revolutionary tendency. Also, the heterogeneity of the middle classes and their psychological tendency to disassociate themselves from the working class were larger obstacles than he had foreseen. Even after the war, his basic views remained largely the same, except now revolution was not the only means to democratic socialism.

Orwell hoped that the inevitable death of capitalism would not necessarily mean the destruction of Protestant morality. Nazi Germany, Stalinist Russia and Franco's Spain were only the beginning of what appeared to be a wave of totalitarian societies. Intellectuals had sworn themselves to these totalitarian ideologies with a fervor not wholly unlike a religion. What is important to remember is that by subscribing to these 
ideologies intellectuals were instantly given power and status. Ideologies, in general, especially Stalinism and fascism, which Orwell considered to be the most immediate threats to the future, devised pictures of the future that left no room for traditional Protestantism and its advocacy of basic freedoms. Orwell believed that the propaganda used by these totalitarian regimes to bolster support could also be used by democratic socialist intellectuals. If Hitler was able to rally the masses by rekindling German mythology and the irrational yet purely human impulses of honor, patriotism and duty, why could not democratic socialists do the same?

Even if the Kingdom of Heaven had died in the minds of many, language stressing traditional Protestant virtues could awaken the spiritual side of man in much the same way as Hitler had done. Orwell closely tied Protestant morality with the traits of the lower classes. He believed that man naturally viewed himself as an autonomous individual, while another side of his innate spiritual nature longed to identify, share, even merge with fellow humans. ${ }^{7}$ That is why men were willing to die for their countries, for countries were comprised of like-minded individuals. Left-wing intellectuals, whether communists or Labour leaders, mainly emphasized economic security to the common man, while underestimating the importance of tradition, much of which in Britain was rooted in Protestant spirituality. Although only a small percentage of the English population went to church or were even consciously religious, "[a] vague theism and an intermittent belief in life after death are probably fairly widespread. ${ }^{78}$ The ethical teachings of Protestantism, which not 
only included "loving your neighbor" and an unsurpassed work ethic but also unselfishness and a strong belief in liberty, had outlasted organized religion and persisted strongly in the lower classes. Orwell realized that collectivization did not necessarily mean the death of all economic liberties or the demise of freedom of thought, which had prevailed in most Protestant cultures. He attempted to merge Protestantism's basic teachings with many traditional principles of socialism. Ironically, Orwell, himself, was an atheist. "Orwell was thus...a man who rejected as irrelevant most elements of Christian belief and a passionate believer in 'the religious sense of life' and in the form of human individuality that Protestantism had nurtured." ${ }^{79}$ Without a Protestant sense of individuality, art forms that required an individual to have a free mind, such as novel writing (which he claimed had largely been a Protestant enterprise), would surely die as they had in Nazi Germany and in Stalinist Russia. ${ }^{80}$ In short, Orwellian socialism attempted to safeguard various freedoms that had always been closely tied to Protestant culture.

Orwell devoted much energy to discussing what might happen after collectivization. The bleaker version, shown in Nineteen Eighty-Four and other late works, borrowed heavily from Burnham's belief that the future would be dominated by a "managerial-styled" totalitarian oligarchy similar to the Soviet government. The new ruling class, made of technicians, bureaucrats, financial experts and middle-management executives, would control the institutions of the state and would never give the worker a vote. It was the very same class that Orwell had earlier hoped to lead the working class to revolution. They would probably label their 
government "socialist" to manipulate the masses, but, in reality, rule would be oligarchical. As a result, rising in the party relied on following doctrine and lusting for power, not on hereditary privilege or economic worth. No one member of the ruling class held complete power; instead, power was divided (though somewhat unequally) among the ruling elite. ${ }^{81}$ Burnham predicted that in these future oligarchies Stalin and Hitler would be reduced to spiritual figureheads. Power would motivate the ruling class and party teachings would guide them. The sadistic desire for power was one way to explain modern trends. For instance, imperialism based all social and political relationships on it. Technology, too, had been perverted by a small number of people. It dehumanized the worker, kept the powerful in power, and was epitomized by the atomic bomb. Like Burnham, Orwell feared that atomic weapons could deter warfare and keep totalitarian regimes indefinitely in power. In the end small nations might become powerless. In Nineteen Eighty-Four, reminiscent of Burnham's belief in large multinational conglomerates, small tracts of land acted as buffer zones between the three superpowers. Stalin and Hitler's regimes paled in comparison to the type of regime Orwell feared might take power. Perhaps Zwerdling's and others' explanation - that Orwell's personality possessed a sadomasochistic component - should be considered, yet Orwell only flirted with Burnham's belief that politics have always been the struggle for power, which, incidentally, was a Machiavellian interpretation of politics. ${ }^{82}$ Orwell's fascination with Burnham's analysis and subsequent use of it in Nineteen Eighty-Four should not be misunderstood; it was a feasible response to the turmoil 
and catastrophe that characterized the times in which Orwell wrote. ${ }^{83}$ In Orwell's final analysis of Burnham, he insisted that Burnham had never bothered to explain the psychological motive behind those in power. He had wrongly made blanket statements about the character traits of the lower-middle class and the nature of politics throughout history to fit his apocalyptic vision. Orwell countered by saying, "why does the lust for naked power become a major human motive exactly now, when the dominion of man over man is ceasing to be necessary". ${ }^{84}$ He reminded that for the first time ever technology made it possible for all classes to enjoy material wealth. Onwell truly believed that a "nearly" classless society was a possibility and in doing so placed great confidence in the human nature of the lower classes. It was even hard for Orwell to imagine the British upper class behaving in such indecent ways.

Although increasingly cynical, Orwell never said that he thought democratic socialism was an impossibility. After all, he had seen something similar function successfully while in Spain. Even in the nightmarish land of Nineteen Eighty-Four, he placed hope until the end in the proletariat. If they could be made to understand the advantages of democratic socialism then they would force necessary change. The antimilitaristic tendency of the lower classes and his unheard call for social revolution in "The Lion and the Unicorn" alerted him that social change might not take place over night or involve bloodshed. All he could be sure of was that it was the socialist intellectual's duty to present the public with an honest, clear blueprint of not only the path to socialism but also of what to expect once there. Despite bitter failure after failure, socialist 
intellectuals had refused to listen to Orwell. They continually failed to appeal to the working class's deep sense of patriotism. ${ }^{85}$ Some confused matters by espousing the confusing rhetoric of ideology. The left wing was anything but united. Several socialist ideologies competed for the same worker. Left-wing movements failed to understand what the masses really wanted. In "The English People," he insisted that the masses had always wanted, "'[e]conomic security, a foreign policy which will ensure peace, more social equality, and a settlement with India"”. ${ }^{6}$ Orwell, not a theorist, but a relentless critic, only made general outlines of the means and ends to socialism. History could not be predicted. He maintained until his death that it was the intellectual's job to instill a version of socialism that safeguarded democratic processes in a simple, straight forward manner to the lower classes. In this essay he offered a few suggestions for the immediate future that were necessary for Britain to follow if it was going to survive as a great nation.

He feared that if the world evolved how it had over the prior twenty years then in the near future there might only be two or three superpowers. Britain lacked the resources and the population to be one of these. At best, Britain could act as not only a buffer between these great powers but also as a model state for these superpowers to emulate. He believed that the British people possessed special traits and had created a rich culture. Even its internal politics were conducted in a humane way. Only in Britain did the possibility exist for liberty to be maintained in a "povertyless" society. The Russians were too authoritarian, while the Americans were too materialistic. Britain needed 
"...a rising birthrate, more social equality, less centralization and more respect for the intellect." ${ }^{87}$ It was necessary for the British to stay on good terms with the Soviet Union and Europe, while special ties were needed with the United States and the Dominions. Throughout his life he continued to advocate many of the same reforms he had called for in "The Lion and the Unicorn."

Incomes were to be limited, major industries nationalized, and education was, to an extent, to be democratized and better funded. He still aimed at removing outward class distinctions. In "The English People," he introduced a few novel approaches, such as the removal of class labels from the English language by teaching British school children only one accent. Also, larger families could easily be encouraged with tax incentives. ${ }^{88}$ By "less centralized" Orwell meant that he hoped to reopen economic and cultural channels in parts of England aside from London. He believed that all of Britain was governed by London politics, economic interests and culture. The British government needed to make outlying parts of Britain, especially Scotland and Wales, more autonomous. ${ }^{89}$ Not only did he hope to see economic growth in these outlying areas but he also proposed that schools should instill local pride in children through the teaching of local history and topography. ${ }^{90}$ In general, Orwell hoped the British people would open their minds to the important issues at hand. For example, rather than spending excess amounts on beer and sporting events, science and literature should be encouraged. The press, too, could be made into an educational device if all commercial interests were removed from it. ${ }^{91}$ As in "The Lion and the 
Unicorn," Orwell hoped the masses, along with left-wing intellectuals, would rally together behind the essay's message. Only then could Britain expect to play a significant role in the future. Even though he no longer called for revolution or talked a great deal about the implementation of democratic socialism, he still advocated it. Only now he was prepared to implement reforms by the process of gradualism. Most of the policies that he advocated could still be traced to his respect for individual rights, long-standing British traditions and the general traits that he ascribed to the working class.

Unlike scientific and utopian socialists, Orwell had always considered morality ( in the form of the traits and traditions of the working class) the foundation of democratic socialism. Working-class morality, as well as democracy, depended on a society not run by intellectuals on the workers' behalf but by workers. Protestant morality and other humanitarian features of working-class life, though not always legislated, would be ever-present in all segments of society. In his ideal state, every able mind and body would be forced to work, which would quickly erode away most class distinctions. All outward signs of inequality would be removed. Hereditary privileges would end, and economic and social disparities would be lessened with legislation. Matters of right and wrong were to be left outside the realm of politics to the intellect. Politics would be the moral expression of the individual. ${ }^{92}$ Orwell never explained the specifics of such a system, but the working classes would be given all decision-making power and the system would center around their general traits and traditions. Freedom to think and even criticize would be 
fundamental rights. He continued until his death to advocate the nationalization of major industries and land, an income cap, and for democratic reform of the educational system. Room remained for small, private businesses. By following and safeguarding these measures, the corruption and class lines common to collectivized societies in Orwell's day would be minimized. Orwell admonished socialist intellectuals who acted as if Eden were created in a day; he reminded that a well working system might take time and that it would never be perfect. 
Chapter II

The Socio-literary Tradition

Sociology gained legitimacy much sooner on the European mainland than it did in Britain during the nineteenth century. In Britain, literature had always been the primary vehicle for understanding human behavior. Literature still held certain advantages over sociology, which lacked an understanding of the irrational, purely psychological impulse innate to all humans. Human behavior was far too complicated to rationalize into a science what the true nature of society and man were. Literature (which includes poetry) was not restricted by methodology. It served better than sociology in understanding intuition, individualism, spiritualism and other irrational impulses. Not until after World War II, which placed Britain nearly a century behind the rest of Europe, would sociology be a respected discipline in British universities. ${ }^{93}$ Yet this is not to say that sociology had not had a profound impact on British society before World War II. Wolf Lepenies traces the rise of sociology across Europe in Between Literature and Science: The Rise of Sociology. Lepenies discovered that in Britain sociology slowly gained acceptance as a legitimate social science in philanthropy and social work (such as that advocated by Beatrice and Sidney Webb). Even the Webbs, especially Beatrice, who helped to popularize sociological methods of 
research, acknowledged the advantages of literature. In fact, Lepenies shows how John Stuart Mill had had a falling out with other utilitarians over the importance of literature. Ironically, a class of British novelists and poets, including Wells and William Wordsworth, soon began incorporating sociological constructions into their writings. Orwell, too, falls into this class of socio-literary writers. Even in Orwell's fiction, he attempted to classify society into exact social groups with the hopes of instilling a class consciousness into the lower classes.

Lepenies begins his analysis on the rise of sociology in Britain with a discussion of John Stuart Mill. For various reasons, Mill had found a spiritual element wholly lacking in his own life and in the rationalistic tradition of utilitarianism, whose early proponents, including Jeremy Bentham, had claimed that literature and poetry had no useful application. ${ }^{94}$ Mill, however, was different. He admired Wordsworth, whose poetry was less concerned with artistic merit than with exact descriptions of personal experiences that attempted to unveil links to universal truths. It thus can be said that Wordsworth, rather than the more artistically gifted natural poets Shelley and Byron, was an early proponent of the socio-literary tradition that came into vogue during the latenineteenth and early-twentieth centuries. Mill also, for similar reasons, admired Thomas Carlyle's French Revolution. It reported the facts in an artistic way so to reveal the underlying nuances of emotion that had been 
neglected by earlier writers. ${ }^{95}$ Mills' life, like that of Beatrice and Sidney Webb, exemplifies the basic tensions between rationalism and emotion.

Although the Webbs were notorious for their overly-scientific methodology in which they chose to concentrate solely on the facts of society, describing them with utmost precision, they hoped to make social research into nothing less than a science. The methodology they hoped to employ went beyond "Gradgrindism" or basing theory solely on facts and figures; in their science of society, they also employed historical research and personal experience. ${ }^{96}$ The Webb's conception of Fabianism was at core not theoretical at all, but was practical and gradualistic. In these ways they brought a humanistic side to sociology while maintaining it to be a science. It soon became apparent to them that Fabianism was too firmly rooted in rationalism. Beatrice hoped that social work could substitute for Christianity. Realizing this to be a failure, they ultimately embraced the holistic ideology of communism. However, throughout their lives, both Webbs saw relevance in literature. Beatrice had always admired Goethe and especially Balzac, whom she regarded as the supreme nineteenth-century example of a novelist with unsurpassed insight into human nature. ${ }^{97}$ In the early twentieth century, she especially admired the "sociological novels'" of Wells. Other twentieth century authors with sociological insights that she noted in her diaries were Santayana and Aldous Huxley. ${ }^{98}$ 
Wells followed Dickens as the next great British author to apply sociology to fiction. Wells went beyond Dickens, who can be described merely as a moralist, by supplying scientific solutions to society's problems, which is especially apparent in his utopian novels, Anticipations and A Modern Utopia. Unlike the Webbs, Wells saw sociology as far from being a natural science yet he advocated the emulation of the latter by the former. He pointed out that sociology failed to take account of the uniqueness of the individual. Instead, he believed that sociology must either be used as part of narrative historiography, such as that used by Carlyle, or in utopian fiction. Because of Wells, it became fashionable during his day to treat literature as descriptive sociology. The two disciplines often overlapped; no matter which discipline, each hoped to produce practical effects. Lepenies linked Wells to a long line of socio-literary writers that included August Comte, Francis Bacon, Thomas More and even Plato. ${ }^{99}$

Orwell falls squarely in this socio-literary tradition. Throughout his life, Orwell viewed not only his essays and journal articles but also his novels as vehicles for social and political change. Orwell believed the novel held an emotional appeal over other styles of writing. It was not as if his novels and essays lacked a sociological element. Characters in his novels are generally not portrayed as individual personalities. Instead, they fit into specific constructions of class, fulfilling the roles that Orwell 
assigned to each of the classes. In Coming Up for Air, George Bowling represents the disenfranchised lower-middle class insurance salesman from the suburbs, while in Burmese Days, Flory represents the British imperial class. The majority of his longer works, excluding Animal Farm and Nineteen Eighty-Four (which should be viewed as final efforts to gain a readership), fall under the label of "social realism." Down and Out in London and Paris, The Road to Wigan Pier and Homage to Catalonia, while not novels, were written in a documentary format that in its own right can be described as "realism." Each in its own way is a field study of an exploited population. Orwell's essays and journal articles, too, were purposely written in a simplified, exact manner. He goes at length not to be seen as an artist but to point out the outlines of society. 
A Review of Orwell's Works

Down and Out in Paris and London

Upon resigning his position in the Indian Imperial Police, Orwell's decision to go incognito in the Paris and London slums had been an attempt to seek redemption for his part in the imperialistic racket. He hoped to unearth the life of another exploited population and expose injustice. He concluded that the destitute and poorest workers were, in general, not destitute or poor by their own faults but were unfortunate byproducts of capitalism. Down and Out in Paris and London, published in 1933 , is a condemnation of capitalism and how it forced many decent human beings into dead-end jobs, or, worse still, into the streets, robbing them of all pride and hope. His strategy for reform was to make them seem human, even virtuous, in hopes that the general public would reconsider the many prejudices that were held against them. By shattering the negative stereotypes that were attached to the poor and destitute, he hoped to spur reform that would instill pride into them. Orwell considered them a sub-caste of the working class but they differed from the working class in an important way. Uneducated and living at subsistent levels had reduced them to walking corpses whose basic worries were a bed to sleep in and food to eat. However, the poor and destitute held much in common with the main body of the working class. The system allowed them no prospects for improvement; they, like the rest of the working class, were resourceless. He ascribed to them, even 
at this early, apolitical phase, the traits of decency, honesty and generosity. Interestingly, he would later use these very same traits in his creation of the myth of the northern British working class.

He gave detailed descriptions of lodging houses and their occupants in order to bring to life the forgotten and neglected. The conditions in the lodging houses were inhumane. The homeless gathered to sleep side by side in cold, cramped and dirty lodgers so to escape the cold, damp nights of Paris and London and to eat trace amounts of stale bread, margarine, tea, and, if they were lucky, cheese. Locked in these work houses like fenced in cattle, they sat idle. The next morning the street's gates were opened and the tramps were forced by law to move on to new shelters. It was prohibited for them to stay in an individual poorhouse for two consecutive days, so they trekked off in search of work, which was nearly impossible to find. Many devised acts and schemes to earn money, but rarely did they earn enough to escape the streets. The system perpetuated this lifestyle. Malnutrition, disease, loneliness and ostracism plagued most and the dole rarely improved matters.

A caste system, not unlike capitalistic society at large, rigidly defined the role and status of each position at the Parisian hotel and restaurant where Orwell worked. Plongeurs, like Orwell, needed little training, worked long hours, were paid just enough to survive and could never advance up the hotel hierarchy. A plongeur's typical day included washing dishes and doing other menial kitchen tasks for twelve or more hours. Chefs, waiters and management all ranked above the lowly plongeur; however, there were even lower positions. To display the hotel's 
prevailing hierarchy, Orwell told about his relationship with one of the waiters. Friendlier than most waiters, the young Italian treated Orwell almost as an equal in private but once around others he spoke condescending and rough to Orwell, and for good reason, because it would have lowered his position in the hierarchy. Other examples of the hierarchy abounded. "[W]aiters in good hotels do not wear moustaches, and to show their superiority they decree that plongeurs shall not wear them either; and the cooks wear their moustaches as to show their contempt for the waiter." ${ }^{100}$ Only cooks in lesser hotels could wear moustaches. Waiters, under no circumstances, were allowed to wear moustaches, for moustaches were thought to be the bourgeoisie's style. Orwell despised waiters more than other members of the hotel staff, for their mannerisms and ambitions had been modeled after the bourgeoisie. In some cases, waiters could get lucky and climb out of their lowly circumstances. Only Saturday nights at the bistro drinking with friends and a growing market of cheap luxuries kept life tolerable for the lowest reaches of the working class.

The upper classes, Orwell insisted, did not want to reform working conditions because they gained materially by exploiting the lower classes. He summed their attitude as, "[W]e will fight like devils against any improvement of your condition. We feel that you are much safer as you are. The present state of affairs suits us, and we are not going to take the risk of setting you free, even by an extra hour a day. So, dear brothers, since evidently you must sweat to pay for our trips to Italy, sweat and be damned to you." ${ }^{101}$ Thus, the negative stereotypes given to the lower 
classes solidified the upper class's power. Discrimination among the upper class was severe, so severe that it was looked down on to appear hungry. ${ }^{102}$ When the economy slumped, it was unskilled laborers that took the hardest blows. Capitalism made it easy for the upper class to stay in power. Even during the best of times, unskilled workers worked in horrid conditions for poor wages.

In Down and Out in Paris and London, Orwell sought to change public opinion by creating new stereotypes for the poor laborer and the destitute tramp. Both held the working-class virtues of generosity and decency, even though they had been thrown into pitiable conditions by circumstances out of their control. Although many had given up hope, a strong sense of solidarity existed throughout these populations. Inside the English pub or in the French bistro the poorest reaches of the working class fraternized in an egalitarian atmosphere. ${ }^{103}$ Working-class distinctions vanished once inside these drinking establishments. Laborers could forget their wretched lives of toil and sweat. An air of equality also existed between the destitute. Inside lodging houses and on the streets, the destitute held a code of morality. They shared food and took care of the aged and sick. Orwell reminded that many of those on the street were living off unsatisfactory pensions. They had been unable to set aside enough money to retire. Others in the British lodge and dosshouses were once proud, industrial workers from northern Britain who had lost their jobs due to erratic market conditions or injuries. ${ }^{104}$ It was not as if either group desired to be poor or destitute. 
Meal tickets and other government hand outs were necessary for survival, but, as Orwell argued, were not beneficial in the long haul. Public assistance was not an attempt to remedy the actual problem of unemployment, only to remove it from the public eye. In Down and Out in London and Paris, he attempted to humanize them by putting names to numbers. As Orwell claimed,

[d]eliberate, cynical parasitism, such as one reads of in Jack London's books on American tramping, is not in the English character. The English are a conscience-ridden race, with a strong sense of the sinfulness of poverty. One cannot imagine the average Englishman deliberately turning parasite, and this national character does not necessarily change because a man is thrown out of work. Indeed, if one remembers that a tramp is only an Englishman out of work, forced by law to live as a vagabond, the tramp-monster vanishes. ${ }^{105}$

Orwell hoped to show that they took public assistance only out of necessity, not because they enjoyed taking from the system. Over time, the poor and destitute naturally became "abject" and "envious." As Orwell said of his mate, Paddy, "[i]t was malnutrition and not any native vice that had destroyed his manhood."106

In it Orwell suggested several social reforms of his own. Each of these reforms centered on the belief that the tramp had to be "depauperized" or instilled with pride to be made to feel more like a human being. Only with a job would tramps fully regain their pride and become productive citizens. Without work, the poor and destitute could never expect to marry and have their own place. So to raise their spirits, he proposed that public lodgings be turned into small, self-supporting 
farms so that any tramp who showed up could be made to do a full day's work. ${ }^{107}$ Other, more immediate reforms were that tramps should be able to stay in lodging houses for more than a day at a time. Otherwise, were not tramps simply wasting energy (which could be used in far more productive ways, such as finding jobs) traveling from doss-house to dosshouse? Hygiene also needed to be improved within the lodging and doss-houses; therefore, those staying overnight were to be provided with clean bedclothes and better mattresses. In addition, he thought that it was important to divide dormitories into cubicles. ${ }^{108}$ Only with humane legislation would the poor and destitute be able to bounce back on their feet and become self-sufficient. 
Burmese Days

Burmese Days, not published in Great Britain until 1935, is primarily a novel about class issues. In it Orwell showed how imperialism restricted the freedom of not only the exploited Burmese natives but also of the British colonists. Orwell links imperialism with the British class system. From his own experiences in Burma, he concluded that British colonists were opportunistic lower-middle class types who exploited the native population for many of the same reasons and in a similar fashion to how the British upper class exploited the British lower classes. These colonists were drawn to Africa and Asia by the promise that they, too, could be the class in charge. It can be argued that while in Burma, Orwell, like Flory, was ambivalent about the effects of British involvement in Burma. Burmese Days, written while Orwell was "slumming" in Paris and London during the early thirties, helped Orwell to come to terms with the class prejudices that were an inevitable part of a middle-class upbringing and for his involvement in Burma. It was in the European slums that he found an exploitation similar to what he witnessed in Burma.

The novel's central character, Flory, inwardly despised the British imperial system because of its oppressive, inhumane nature yet could never muster the strength to take a stand against the vulgar, base racism of his countrymen. For example, he continually allowed the other British at the exclusive European Club to degrade his Burmese friend, Dr. Veraswami. Flory was not above exploiting the natives either. He, like the other colonists, had servants whom he generally treated well; however, at 
key moments, he used them for his own selfish purposes. The worst instance of abuse came when he kicked out into the streets his servant and live-in mistress of two years in order to hide her identity from an English woman, Elizabeth Lackersteen. Shallow and materialistic, Elizabeth had an innate desire to marry someone at least of her station, if not higher. Flory did his best to mask from her an underlying sympathy for the Burmese, yet at inopportune moments this sympathy surfaced in unusual ways. In the end his puzzling treatment of the Burmese would help to drive away Elizabeth, who, like the other British, thought his behavior to be improper, revolting and perverse. Flory's only escape from this bleak world was to take his own life.

The few British on the lonely outpost considered themselves to be civilizers of crude "niggers." They were gentlemen amongst animals, it was believed. Although they regarded themselves as the upper class, Orwell was quick to point out that a majority of British colonists were little more than the lower-middle class once inside Britain. The middle class, Orwell concluded, was especially susceptible to class envy. They came to the corners of the earth in search of material opportunity and a "gentlemanly" status that could not be found inside Britain. Orwell, himself, had come from such a family. Like his father, he went to Burma in search of status. Later, Orwell repeatedly mocked the stupidity of the British colonists, many of whom had lived in Burma for years without ever learning to speak a word of Burmese. The upper class in Britain were also blatantly ignorant about the classes below them. It should come as no surprise that the British on the outpost kept to themselves and had no 
understanding of Burmese culture. All were materialistic and greedy; some, such as Ellis, could easily be prompted to act sadistically towards the natives. Most of the men spent their many leisurely hours drinking at the European Club, where they glorified their previous lives back in Europe and schemed of new ways to exert control over the Burmese, who had grown discontent with British rule. It should be remembered that by the time Orwell arrived in Burma, Burmese nationalism had begun to grow. Like their real-life contemporaries, the natives in Burmese Days demanded democratic reforms and autonomy that were met by the British with bitter resistance. ${ }^{109}$

The absurdity of the class system is exposed when the Honourable Verrall, a brash young, high-ranking military officer, stayed at the outpost for a short stint. He preferred the life of a recluse over spending time with the other colonists whom he considered to be of a lower class. He treated them only slightly better than the natives, whom he also despised. At first, he ignored the beautiful Elizabeth. Gradually, however, she gained his eye. In hopes of a marriage to a member of the elite, she instantly broke off relations with Flory. The stupidity of the British upper class was exhibited when Verrall bragged to her that he had only read one book in his entire life. They laughed together and agreed that highbrows, like Flory, full of ideas, were not to be admired but to be condemned as fools for weighing so heavily on abstractions. Yet, Verrall never had any intention of marrying Elizabeth. Verrall, the typical British upper-class materialist, was only concerned with having fine clothing and enough food 
to feed his polo horses. In the end, he left without saying good-bye to the penniless Elizabeth.

Orwell's characterization of the Burmese was a complex one. He showed that the British rewarded those willing to embrace their culture. However, to be part of this elite class of Burmese meant to adopt British ways, which included the exploitation of the native population. The Burmese elite were still looked upon with suspicion and as second-class citizens. Even still, Dr. Veraswami considered his countrymen to be backwards and uncivilized. A worshipper of power (much like the British "Russophiles"), he considered British rule to be a blessing, for only could the British enlighten his countrymen and bring law and order. His adversary, U Po Kyin, typified the Burmese minor administrator. The cunning glutton gained power and influence by bribing and extorting money from his own people. In truth, both men played only minor roles in the system of exploitation. The Burmese upper class, without regards to the general welfare of their countrymen, took orders from the British. Orwell characterized the rest of the Burmese population as simple, decent and untainted, not wholly unlike the poor and destitute in Paris and London. All that was wrong in Burma could be attributed to the British. An example of their destructive tendencies took place when Flory's mistress is all but forced to work in a brothel after he needlessly kicked her out of his home.

It is no mistake that Orwell's more developed characters are British. While in Burma, Orwell spent little time with the Burmese; witnesses during this time described him as introverted and reclusive. He surely did 
feel compassion for the Burmese while there but he had no real Burmese friends or extended contact with them. The Burmese characters were thus created to showcase the effects of British imperialism. In effect, he sentimentalized the Burmese, much as he later did the British working class. For instance, like he did with the British working class, he connoted a smell - garlic and coconut oil - with the Burmese. The best example of this sentimentalization of Burmese life came when Flory took Elizabeth to a pwe-dance.

Just look at that girl's movements - look at that strange, bent-forward pose like a marionette, and the way her arms twist from the elbow like a cobra rising to strike...There's a touch of the diabolical in all Mongols. And yet when you look closely, what art, what centuries of culture you can see behind it! Every movement that girl makes has been studied and handed down through innumerable generations. Whenever you look closely at the art of these Eastern peoples you can see that civilization stretching back and back, practically the same into times when we were dressed in woad. In some way that I can't define to you, the whole life and spirit of Burma is summed up in the way that girl twists her arms. ${ }^{110}$

It was such ancient traditions and customs that British imperialism and capitalist culture destroyed. Orwell lamented this fact. 


\section{A Clergyman's Daughter}

In A Clergyman's Daughter, completed in 1934, Orwell examined the state of Christianity in Britain. It is centered on the life of an Anglican rector's daughter, Dorothy. In a complex way, Orwell showed that even the faith of the pious - Dorothy - had fallen prey to the pitfalls of the modern world. The rector and his congregation were no better. For most, rituals were all that lived on; for those few who still truly believed in life after death the prospects of a happy life on Earth were slight. Christianity was no longer an active faith built on the premise that life on Earth could be good. For the lower classes, the fruits of salvation were only to be enjoyed after death; until then, life would be filled with hard work, oppression and misery. Yet, Protestant morality did give the congregation a code to follow. It gave monotonous, hard lives substance. However, for intellectuals and the upper class, organized religion had been outmoded by political ideologies and, even more commonly, by money. The hedonistic artist, Warburton, who courted Dorothy, fell prey to such vices. For Dorothy it was the effects of a monotonous, grueling schedule that eventually caused her to lose her memory and flee her hometown. In a documentary-styled format, Orwell gives an up-close look at Dorothy's life on the streets, in the hopfields and lastly teaching in a run-down private school. These experiences seemingly strip the faith out of the once naive and pious Dorothy. With nothing to clutch onto or no routine to follow, 
she returned home to her old life as "the rector's daughter," not out of devotion to God or her father but to regain a sense of security that only her routine of old could give her. In this way she differed little from those who transferred spirituality to money or ideology. However, religion did promote decent behavior, which could not be said for money or ideology.

In A Clergyman's Daughter, Orwell showed that everyone was naturally endowed with a certain amount of spiritual energy. Religion - namely Christianity - had fulfilled man's spiritual needs until modern times. But with the rise of science during the Enlightenment and the subsequent flurry of industrialism and urbanization, age-old customs, crafts and trades increasingly came under challenge. By the twentieth century, nearly all businesses had been monopolized and mechanized, which, in turn, dehumanized the worker. With no real worth to be found on the job, the working class looked to cheap consumer goods to fill the void. Orwell never criticized the worker for consuming luxury items; he always claimed this to be a natural reaction to the capitalist system. Organized religion had begun to die even amongst the working class. The working class, Orwell believed, had even begun to drift away from Christianity. Even if part of the working class had started to doubt the validity of the creation story and other important Christian doctrines, they still clung to Protestant ethics. The working-class family based its code of behavior on such ethics. It was in the upper-middle and the upper classes, as well as among 
intellectuals, where Christianity saw its greatest decline.

Capitalism had made possible a materialism that entrapped these classes. The worship of money had become commonplace. Spiritual energy in these "enlightened" classes was transferred into other forms as well. Political creeds claimed to offer holistic solutions yet were not spiritualistic enough to solve man's ills. Hedonistic forms of socialism only promised the working class higher wages, and Marxism even denied the existence of an omnipotent power. Orwell believed that these left-wing ideologies could never solve the basic spiritual needs of man. In societies where ideology had replaced Christianity, leader worship had ensued. Hitler and Stalin had been all but crowned as gods. Orwell feared humans would be spiritually unfulfilled in the future.

The story is about an Anglican clergyman's daughter who by means of amnesia fled from her unhappy life. With little prospects for marriage and an overbearing father unable and unwilling to do anything for himself, life was highly ritualized and monotonous. Change appeared an impossibility, but she seemingly held to Christianity with an infallibility unmatched. A sort of ascetic, she would prick her arm at the onset of too pleasurable of a thought or what she contrived to be an "unchristian" impulse. At times she found solace in her tiring schedule of visiting members of the congregation, organizing and heading church committees, and taking care of her father. Her flight from her hometown was a subconscious reaction to the grueling monotony of her schedule. 
Once she leaves this maddening yet relatively secure existence, she is immediately thrown into a world of uncertainty. At first she supported herself hop-picking; then she lived as a vagrant in the London streets; and lastly she found a teaching position at a rundown private school. Like her life before, she had no time to think about anything other than the task at hand. However, in each instance, she also had to worry about food to eat and a roof over her head. When her memory returned, the impact of these experiences left her changed. She no longer believed in God; however, once the opportunity afforded itself, she returned home to her life of old. When asked by Warburton why she was returning home to live the life of a Christian, even though she was not one, she could not convey but knew in her heart that it was the rituals of old, and not God; that had given life substance. Without these rituals, she had no foundation. "She did not reflect, consciously, that the solution to her difficulty lay in accepting the fact that there was no solution; that if one gets on with the job that lies at hand, the ultimate purpose of the job fades into insignificance; that faith and no faith are very much the same provided that one is doing what is customary, useful, and acceptable."111 Her belief in Christian ethics still came naturally to her. Orwell, an atheist himself, believed the preservation of Protestant ethics, which still persevered in working-class homes, was of utmost importance. Protestant ethics were of a more decent variety than the ethics promoted by political ideologies or money. 
Christianity affected other characters far differently than it did Dorothy. For instance, Dorothy's father regarded the lower classes contemptuously, mostly because he was part of the landless gentry whose income and status had slipped in modern times. "In his purely clerical duties he was scrupulously correct - perhaps a little too correct for a Low Church East Anglican parish. But that a clergyman has any duties outside the four walls of the church was a thing that had never seriously occurred to him." ${ }^{112}$ He left the dirty work to his wife and, after her death, to Dorothy. The rector was unable to get along with either the lower or the upper classes in the congregation. He would have been right at home a couple centuries earlier, Orwell claimed, but now without income and a waning status, he brought a patronizing, disgruntled attitude to the world. Because of his bloated conception of himself, he refused to live according to his income. His lavish tastes created huge debts around the small town, which, Orwell claimed, was not untypical of the British clergy, especially the Catholic and Anglican. Like many Catholic intellectuals, the rector was a reactionary who worshipped money.

Christianity offered a bitter pill to the working class. In ill health, old and with no prospects for change, Christianity was all that Mrs. Pither had. "Mrs. Pither had only two subjects of conversation; one of them was the joys of Heaven, and the other the miseries of her present state..113 Christianity offered no immediate help to the masses, other than a behavioral code and the promise of an afterlife. It was no wonder Christianity had continually declined; it offered no immediate solutions to the working class's social ills. 
The minor artist Warburton represented the hedonistic socialist that had become common in the twentieth century. He always joked that if you took chapter thirteen out of I Corinthians and in every verse wrote "money" instead of "charity" then it would have more meaning. The small town regarded him as immoral and eccentric. He had lived out-of-wedlock for many years with a foreign girl. After she left him, he began courting the much younger Dorothy. In one scene he argues to Dorothy that Christianity was a dead religion, claiming that a hedonistic lifestyle was the practical way to live life. "'Good gracious! What do you want with a meaning? When I eat my dinner I don't do it to the greater glory of God; I do it because I enjoy it. The world's full of amusing things - books, pictures, wine travel, friends - everything. I've never seen any meaning in it all, and I don't want to see one. Why not take life as you find it?"'114 The downside to this happy-go-fucky ethos was that it lacked substance. For this reason, Warburton could never find contentment.

Orwell gave an in-depth analysis of poverty by way of Dorothy's flight into the unknown. In a documentary style, much like he had earlier used in Down and Out in Paris and London, he described the life of a hop-picker. Though hard and grueling work, he romanticized late summer days spent picking hops in the British countryside. Even though the hop-pickers were exploited by the farmers (who basically had to in order to survive themselves), a sense of happiness and camaraderie existed among the hoppickers. Whole families worked side by side. Everyone shared food with the needy, even if it was his or her last morsels. At night 
the encampments would come to life with the sounds of folk music, drink and laughter. These songs humorously conveyed the injustices occurred on the poor. For many hop-picking in the countryside was the happiest time of the year, especially for those who had traveled from the London slums.

Once the summer ended, Dorothy left the countryside for London in search of work. For days she could not find work. Her educated accent and ragged clothes had signaled her out to employers as immoral and indecent. How else, the upper classes reasoned, did she end up in such lowly circumstances? While on the streets, Dorothy was taken in and helped by a group of beggars. Even the vagrants had a basic decency about them. They, too, sung songs about the hardships of life.

She eventually fell into a dead-end teaching position at a lowly private school. She found her students to be unbelievably uneducated. It was not the students' fault, but the teaching methods of her predecessors, she reasoned. The children reacted positively to her innovations, wit and never before seen diligence. They also liked her for not being too stern or cruel, even though Mrs. Creevy had insisted that all effective and moral teachers were hard on students. Mrs. Creevy, the tired, old schoolmaster soon intervened after a parent complained about Dorothy teaching Shakespeare to the children. She insisted on a return to previous teaching methods and a sterner rule. She justified her intervention by claiming everything revolved around money. Children were to be treated according to their parent's income; after all, these students paid the bills. 
The children held Dorothy responsible for the changes in curriculum and thus returned to their apathetic ways. However, Mrs. Creevy and the parents were content. In the end, Mrs. Creevy fired Dorothy because she had found another teacher - a notoriously bad one - who had promised to bring several new students with her to the school. Again, as always, the system ensured a poor education to the lower classes and offered no rewards for the hard working. 
Keep the Aspidistra Flying

Orwell wrote the majority of Keep the Aspidistra Flying in 1935 shortly before he committed himself to democratic socialism. It is an argument against capitalist civilization. The evils of having too much money, as well as having too little, are unveiled in it. The main character, Gordon Comstock, makes war on the "Money-God" by quitting his job at New Albion Publicity Company because he felt copywriting, by nature, was selling out. In place of lower-middle life, he chose to work dead-end jobs that allowed him only a subsistence existence. He wrongly assumed that not selling out and living in the slums would enhance his poetry. It actually had the opposite effect because it was the luxuries, such as cigarettes, beer and dinner at a restaurant with his girlfriend, Rosemary, that had made life bearable. Gordon held stubbornly to his decision until Rosemary turned up pregnant. Not wanting her to have to have an abortion or raise a child alone in poverty, he makes the only "decent" decision and asks her to marry him. He then returned back to his copywriting position at New Albion in hopes of raising a family in the lower-middle-class suburbs. He did this not because he advocated capitalism but because it was the only ethical choice. Orwell demonstrated that without a restructuring of society that it was nearly impossible to lead a fruitful life apart from capitalistic society.

In the story Orwell characterized each class in British society. He showed that escape from the working and lower-middle class was nearly impossible. The mannerisms of the lower-middle class differed from the 
working class's. They were more refined and educated and at times mingled with the upper classes; whereas, the working class was portrayed as crude yet decent. Orwell gave a moving description of the lowest rung of the working class when Gordon quit New Albion and submerged himself in the slums. On a social level, he finally felt free to do as he wished. Neither his landlord nor his neighbors cared what time he got home at night or what he did behind closed doors. He no longer had to deal with the artificialities of class ritual. Part of the reason Gordon had moved into the slums was to escape the rules, restrictions and snobbery of lower-middle-class life. Unlike many from his socioeconomic background, he had no desire to be materialistic or move up a class. Growing up, he witnessed how his family barely got by yet still tried to put on the air of being middle class. Gordon's family, like Orwell's, was part of the landless gentry, who had sunk financially after World War I. What Gordon eventually found he could not escape was the need of money. Only in the end did he acknowledge that without money life became nearly unbearable. "Money again, always lack of money! Lack of money means discomfort, means squalid worries, means shortage of tobacco, means ever-present consciousness of failure - above all, it means loneliness." 115 In fact, by the time Rosemary turns up pregnant he had all but shriveled into a living skeleton. His life resembled his filthy and disordered apartment. What little money he did earn writing poems and at dead-end jobs, he squandered on superficial luxuries. Although living amongst the lower rungs of the working class, Gordon can not be described as the standard proletariat character. He was more or less a 
lower-middle-class intellectual with foolhardy aspirations of being a writer. His flight into the slums somewhat resembled Orwell's time in the Paris and London slums. Moreover, he lived far below the average working-class salary. He had submerged himself so deeply into poverty that even decency - a fundamental trait of the working class and poor had begun to dissipate. Even when Gordon took back his job at New Albion, Orwell made it explicit that life would be easier financially but would remain a struggle. The price of purity was too high; poverty stole away the little things that had made life tolerable. Even though he would help keep the Money-God adrift, meaning and purpose would be found away from work in the suburbs with his family. Only a total restructuring of society could have prevented this scenario.

Although Gordon resented the upper classes for advocating capitalism, he envied yet despised the ease and security in which they lived. He especially detested that upper-class snobbery, materialism and elitism had become commonplace among left-wing intellectuals. His best friend, Ravelston, was one such upper-class socialist. Ravelston truly was a decent gentleman, who, in theory, advocated socialism. However, he had no grasp of what it took to be a leader of the workingclass. Orwell showed that Ravelston's decency could be deduced to the simple fact that he was rich and could afford to be generous. Orwell modeled Ravelston's character after the typical socialist leader. Although Ravelston liked Gordon and other literary members of the lower-middle class, actual contact with the lower classes repulsed him. This tendency surfaced when a drunken Gordon tried to pick up two lower-class women 
on the street. At this point both men realized Ravelston's underlying aversion to the poor. When the working class did not repulse him, he was out of place around them, which could be seen when Ravelston and Gordon have a beer at a working-class pub. ${ }^{116}$ Although theoretically a socialist, Ravelston was, above all, a member of the upper class. Orwell later attempted to remove such class prejudice from the socialist movement. His other portrayals of left-wing intellectuals were even harsher. He lashed out against the London elite led by Auden and Spender. ${ }^{117}$ Gordon, like Orwell, despised them for being exclusionary. They fought to keep the proletariat out of their ranks, even though they were supposedly writing on its behalf. An aspiring writer needed a degree from Cambridge or Oxford to get published. ${ }^{118}$ Negative references to left-wing intellectuals extended to Huxley, Wells, Marx and Lenin. ${ }^{119}$ Gordon, like Orwell during this time, chose to remain largely apolitical.

In summary, Orwell challenged the life that capitalism thrust upon the lower classes. With Gordon as his mouthpiece, Orwell put forth the belief that British society measured a man by his income and the class from which he hailed. What was worse was that it was nearly impossible for the working class or even the lower-middle class to escape from the class into which they were born. Both classes worked their entire lives only hoping to have enough to pay rent and feed the children, while the upper class lived secure lives without worry. It really was pleasant to live like Ravelston. What Gordon lamented throughout was that people worshipped money. The lower classes did so out of necessity, while the 
upper classes did so out of greed. He had a problem with a system that caused such inequality. Inequality separated the upper classes from the lower class to such a degree that neither could relate to the other. The dole only worsened tensions between the classes. At the time Keep the Aspidistra Flying was released, Orwell was very nearly committed to democratic socialism. His grievances against capitalism were numerous, but rather than drop out of civilized society altogether as Gordon attempted, it was best, at least at this date, to live a decent life within the constraints of the system. How else was there to live? After all, living without money proved to be miserable for Gordon, and advocating a social revolution as he did during World War II was the product of years of contemplation and had much to do with the revolution he would soon see in Spain. Gordon's decision to accept the prevailing norm foreshadows what Orwell would later bitterly conclude about the working and lowermiddle classes. Moreover, Gordon's attempt to escape the system is an early indicator that Orwell saw no choice but a complete restructuring of society. As Ravelston said to Gordon, "'[t]he mistake you make, don't you see, is in thinking one can live in a corrupt society without being corrupt oneself. After all, what do you achieve by refusing to make money? You're trying to behave as though one could stand right outside our economic system. But one can't. One's got to change the system, or one changes nothing." ${ }^{120}$ In the end, Gordon elected to be a part of the lowermiddle class, at least he would be able to live like a human again. 
The Road to Wigan Pier

Written in 1936, Orwell divided The Road to Wigan Pier into two very different parts. In the first he gave a first-hand account of working-class life in northern England. While he did his best to accurately portray the working class, his assessments of the effects of low pay and high unemployment were biased and overly sentimental due to his growing obsession with working-class populations around the world. Though it would not be until his experience in the Spanish Civil War a year later that he outwardly accepted socialism, he was, at this point, nearing an affirmation. The Road to Wigan Pier alerted all the British classes of industrialism's ill effects on the northern British working class. Orwell hoped to destroy unjustified prejudices against the northern proletariat. Contrary to popular prejudices against the northern working class, Orwell celebrated northern working-class traditions. In a similar manner, he had attached the traits of decency and generosity to the Burmese natives and the slum populations in Paris and London; however, his examination of the northern British working class went far more in depth. It is in The Road to Wigan Pier that Orwell began creating the myth of the northern British working class. The ultimate success of democratic socialism rested on the viability of this myth. The second part of the work diverged greatly from the first. In it he gave instructions to left-wing intellectuals on how better to conduct a socialist movement. He criticized left-wing intellectuals, most of whom were from the upper and middle classes, for having class prejudices against the northern proletariat. He admitted that 
he had also been prejudiced against the working class; this was an inevitable result of the British class system. It was no wonder British socialism had failed to gain hold, even amongst the working class who it promised to help. He advised the British left to speak plainly to the lower classes (the working and lower-middle classes) about a simple, comprehensive socialist program; to quit making unrealistic promises about a perfect socialist society; and, among other things, to make the movement more democratic.

A disparity of wealth existed between the upper and lower classes. In recent times the incomes of the upper crust of the middle class had begun resembling the upper class, while the incomes of the lower-middle class were much closer to those of the working class. Status could also traced back to the feudal system. Customs and manners factored into defining class at least as much as income. Orwell claimed to have come from the "lower-upper-middle class," whose upper-class mannerisms and outlooks increasingly did not match its income. It strived to set itself above the lower classes. Its heyday had been before World War I when incomes matched pretensions. Orwell's stint in Burma exemplified the journey that many members of this class took part in to regain lost wage and status.

Hatred of the lower classes was learned during childhood. For example, as a boy Orwell was not allowed to play with the plumber's children. Class distinctions were perpetuated in the public schools. Members of the working class were easily recognized by the upper classes because of their "...coarse faces, hideous accents and gross 
manners."121 Orwell claimed the working class had grown more "servile" over recent times because of growing unemployment, which had, in fact, done much to quiet the middle-class belief that the working class was inherently lazy and chose unemployment. Orwell took this as a sign that the middle class had begun to realize the fragility of the system. Also, the working class, especially in southern Britain, dressed and acted more like the middle class due to the rise of cheap material goods. This lessened outward class distinctions but by no means eliminated class prejudices. The northern British proletariat, which was more resistant to change, increasingly took the brunt of the upper classes' jokes.

He reported in The Road to Wigan Pier that Burma first offered him proof of the class system's evils. In Burma, racism, oppression and rigid class distinctions characterized British rule. The treatment of the Burmese and the poor and destitute in Paris and London did not differ that much from that of the northern proletariat. Stereotypes dehumanized each population into mere objects. By doing so, the social, political and economic exploitation of these populations was rationalized. The upper classes masked exploitation under labels such as "the white man's burden" and "laissez-faire." The upper classes' prejudices against these populations often bordered on the ridiculous. For example, it was commonly believed that the working class lived in caravans by choice, or that the working class smelled because it did not want to be clean. In truth, many did not have access to or could not afford baths. In Burmese Days, the British colonists also claim the Burmese are unclean and smell of garlic. 
Orwell gave a sociological interpretation of why the left wing had failed to build a strong socialist movement in Britain. A revolutionary sentiment had swept into the air of England soon after World War I. It was the revolt of the younger generation against the older, which mainly resulted from the war. The old had called the shots while the young had died in the trenches. Not until after World War II would the older generation relinquish its rule. Unlike in generations past, positions of power and wealth were hard to find for the new generation of educated upper classes. As a result, it became fashionable to become a "Bolshie" or anything vaguely anti-authoritarianism. New "isms" - from atheism to pacifism - sprang up everywhere. The younger generation thus wanted a radical alteration of British society, while maintaining the same basic snobbish outlooks of its parents. ${ }^{122}$ The worldwide depression of the thirties only exacerbated this radicalism.

The revolutionary intellectuals of Orwell's generation claimed they were free from the class racket. Orwell believed they did not really want class distinctions to end, nor did they think revolution a real possibility. The British intellectuals enjoyed their new status, whether as communists, Labour leaders or trade union officials. ${ }^{123}$ Most, even those few who had been raised in the working class, soon embraced bourgeois culture. Orwell believed these "snobbish" revolutionaries were turning away potential supporters of socialism. How could the 
cause possibly hope to eliminate class distinctions if its leaders were embracing the same habits and manners of its supposed enemy? Socialist intellectuals had forgotten the foundation of any good labor movement, the proletariat. Orwell believed that a successful socialist movement in Britain would be a simple, democratic movement, based on the northern working-class values. The various intellectuals on the left misinterpreted the needs of the working class. "But what he does not grasp is that Socialism cannot be narrowed down to mere economic justice and that a reform of that magnitude is bound to work immense changes in our civilization and his own way of life. His vision of the Socialist future is a vision of present society with the worst abuses left out, and with interest centering round the same things as at present - family life, the pub, football and local politics." ${ }^{124}$ Socialism to intellectuals of most all left-wing ideologies was not democratic or even revolutionary at all; it was a reordering of society from the top down. Orwell insisted that socialist ideologies must put aside ideological differences and devise a simple and democratic movement geared to the working class. Otherwise, a socialist movement would never gain hold, and the traditions of the northern proletariat would vanish as had happened with the southern working class. As he summarized, "All that is needed is to hammer two facts home into the public consciousness. One, that the interests of all exploited people are the 
same; the other, that Socialism is compatible with common decency." ${ }^{125}$ Segments of the middle class would be needed if democratic socialism was to gain hold. Even at this early date, Orwell thought the lower-middle class had to be alerted that it was being exploited and that its financial interests were closely aligned with the working class. ${ }^{126}$ Orwell believed it was therefore necessary to begin creating new, more positive conceptions of the working class. To win any class over to democratic socialism, intellectuals would first have to give an honest, concise account of why socialism was the practical choice. To focus too much energy on class distinctions was futile. Do not, he warned, aggravate potential support by "bourgeoisie baiting." "Yet I believe there is some hope that when Socialism is a living issue, a thing that large numbers of Englishmen genuinely care about, the class-difficulty may solve itself more rapidly than now seems thinkable."127

Orwell hoped the middle class would sympathize with his nightmarish description of industrialism's effects on northern workinglife. He did not condemn industrialism in itself, for, with careful planning, it could be used to spread prosperity to the working class. A return to pre-industrial past as the anarchists proposed was ludicrous. Yet, Orwell pointed out how industrialism had destroyed the once beautiful landscape in parts of northern Britain and had been misused 
by big business to oppress the proletariat. There was little compensation for workers injured on the job. Nor did workers know when they might be laid off. Much of the ugliness and squalor of the north directly related to the profit-first attitude of the upper class. Even sadder than the slag-heaps and dirty water was the unhappy lives that lived there. He went at pains to show that high infant mortality rates and the commonality of rotten teeth were directly related to the lifestyle that industrialism perpetuated. Industrialism encouraged unhealthy living and cheap substitutes for everything. Orwell concluded that the working class rightfully chose the "tasty" food over the healthy to add spice to a monotonous existence. He outlined industrialization's implications.

Machine-production suggests Socialism, but Socialism as a world system implies machine-production, because it demands certain things not compatible with a primitive way of life. It demands, for instance, constant intercommunication and exchange of goods between all parts of the earth; it demands some degree of centralized control; it demands an approximately equal standard of life for all human beings and probably a certain uniformity of education. ${ }^{128}$

It was thus a very powerful force that needed to be monitored. He opposed Wellsian-types who claimed technology was an all-powerful and benevolent force that in the near future would be used to create a paradise. He reminded that the Nazis had built a state-of-the-art military with superior technology. Technology, he believed, would inevitably lead humans to be "soft" and lazy. In the not too distant future, Orwell feared there would no longer be a need for craftsmanship or artisan trades; 
machines would be able to do what humans had done for centuries. "For man is not, as the vulgar hedonists seem to suppose, a kind of walking stomach; he has also got a hand, an eye and a brain. Cease to use your hands, and you have lopped off a huge chunk of your consciousness." 129 In time, the qualities of strength, creativity and generosity would be lost, for they would no longer be needed in such an overly-mechanized society. ${ }^{130}$ Orwell warned against the common belief that all that was new was good. Mass-produced clothing, food, housing, books, even weapons, were not necessarily better, yet their "modernity" and affordability assured acceptance. $^{131}$

Orwell drew more from what he viewed in the homes of the northern proletariat than truly existed. Not every home, as Orwell would have the reader believe, was dirty, without running water or bathrooms, and filled with bugs. For instance, his description of a working-class woman he viewed from a train unclogging a waste pipe with a stick went beyond the common perception.

She had a round pale face, the usual exhausted face of the slum girl who is twenty-five and looks forty, thanks to miscarriages and drudgery; and it wore, for the second in which I saw it, the most desolate, hopeless expression I have ever seen...She knew well enough what was happening to her - understood as well as I did how dreadful a destiny it was to be kneeling there in the bitter cold, on the slimy stones of a slum backyard, poking a stick up a foul drainpipe. ${ }^{1}$

His descriptions of the conditions in the coal mines went beyond actual circumstances. The working conditions of the mines, he made it seem, were hellish at best. The mines were appallingly dirty and extremely hot, where miners hunched in dim, small spaces and labored 
for hours for the most meager wages. While it is true that in Orwell's day mining operations were low paying and dangerous, his stories seem exaggerated, even far-fetched. For instance, he includes more than one gruesome account of an accident. "He lies crushed under several hundred weight of stone in some dreadful cranny underground, and even after he has been extricated it is necessary to drag his body a mile or more, perhaps, through galleries where nobody can stand upright."133

Not only did Orwell exaggerate the severity of working conditions in the mine, he also romanticized life inside the northern British working-class home.

Interestingly, Orwell glorified traditional gender roles, which is not all that surprising, since working-class homes were slow to embrace anything non-traditional. These traditional aspects of working-class life could only be found in the north. Orwell had, to a degree, bought into parts of the age-old myth of the "cult of northernness". No matter the class in the north, northerners had long considered themselves to be gritty, warm-hearted and, surprisingly, democratic, while southerners were snobbish, effeminate and lazy. ${ }^{134}$

Orwell glorified the traditional gender roles that still prevailed in working-class homes. He emphasized the simplicity, decency and genuineness found in northern working-class families. Northern working-class life contrasted with that in southern Britain.

Northerners resented the sophisticated, pretentious culture of southerners. Even the southern working class attempted to dress and speak like the middle class. Southerners considered northerners to be uncultivated and primitive. Northerners' accents sounded uneducated, 
and new fashions and ideas were noticeably slower to catch on in the north. Orwell attempted to show the myth for what it really was. He explained that until recently northern England had always been a rural culture and naturally had been slow to change. Because of its agrarian heritage and distance from London, feudal traditions had persisted longer in the north than in the south. Orwell pointed out that while industrialism had defaced many northern factory towns, only a short distance away was the sparsely populated and beautiful countryside. He even suggested it should be parceled out to the unemployed and farmed. ${ }^{135}$ His time among the miners also destroyed his own "southern perception" that the proletariat was rough and course; they treated him with a generosity unmatched.

He further outlines reasons for regional differences.

For climatic reasons the parasitic dividend-drawing class tend to settle in the South. In a Lancashire cotton-town you could probably go months on end without once hearing an 'educated' accent, whereas there can hardly be a town in the South of England where you could throw a brick without hitting the niece of a bishop.

Consequently, with no petty gentry to set the pace, the bourgeoisification of the working class, though it is taking place in the North, is taking place more slowly. ${ }^{136}$

Orwell feared that bourgeois culture would destroy northern workingclass traditions as had happened in the south. The traditions of the north lived on in corner pubs, mines and factories, and in workingclass homes. In pubs and on the job, an egalitarian atmosphere prevailed. It was a similar egalitarian atmosphere that Orwell would 
soon find among the Spanish working class. Orwell hoped to preserve this northern culture by making it the foundation for democratic socialism. 
Homage to Catalonia

Homage to Catalonia is arguably Orwell's best work and is an essential source to understanding his political outlooks. His time in Catalonia in 1937 proved to him that a classless society run by the working class without bourgeois or intellectual influence was possible. Unlike the British working class, the Spanish working class had gained a class consciousness. This, in part, led him to proclaim himself a socialist. Unlike most other intellectuals at the time, his political views were shaped by first-hand experiences. For instance, the overthrow of the Spanish working-class by the Soviet-funded Spanish Communists proved to him that communists worldwide were only concerned with gaining power, not with the creation of egalitarian societies. To his surprise, the Spanish Communists were anti-revolutionary and aligned with the bourgeoisie. It was also in Spain that Orwell saw the actual workings of anarchism and fascism.

The revolution that took place in parts of Spain was not a coup d'état in the purest sense; it did not involve a complete overthrow of the old regime. It is true that in many areas of Spain trade unions took over the means of production of major industries; local soviets (or worker's committees) were set up to govern; and lands were collectivized after the peasants stripped ownership away from the large landowners. ${ }^{137}$ The anarchists and socialists who orchestrated the revolution were not doing these things to preserve capitalist democracy (which they regarded as a racket), but were hoping to reform society with high-minded, egalitarian ideas. 
Yet, many government officials from the old regime remained in power, even on local levels controlled by the anarchists and socialists. With Franco knocking at the door, it was important for the workers and the antifascist segment of the middle class to stick together. For this reason bloodshed was minimal and a complete overthrow of the old order was inadvisable. Even still, Orwell was overwhelmed by the fact that "...there was a belief in the revolution and the future, a feeling of having suddenly emerged into an era of equality and freedom. Human beings were trying to behave as human beings and not as cogs in the capitalist machine." ${ }^{138}$

Workers' militias based on individual trade unions and political parties were set up to defend the new republic. In the ranks of P.O.U.M., the small anti-Stalin, communist militia that Orwell served, equality was stressed within the ranks. For tactical reasons, there were, of course, officers, yet outward class distinctions were effectively eliminated. For instance, Orwell's commanding lieutenant insisted on his troops calling him comrade rather than senor, which indicated traditional class distinction. ${ }^{139}$ Discipline in the militia was voluntary and based on class loyalty. Its success depended on the installation of a political consciousness into the main body of troops. ${ }^{140}$ It was believed that fighting morale was strengthened by an understanding of the "cause" and why orders were being given. The structure of the militia was a microcosm of a classless society, for it was based on democratic ideas rather than on hierarchy. Even the old pro-capitalist police force was replaced by workers' patrols. The revolutionary consciousness of the Spanish working class was more far-reaching than Orwell had ever 
thought possible. In short, the snobbishness and greed of capitalism had been replaced not by a planned economy run by intellectuals but by a society run by workers. What attracted the workers to revolution was what Orwell called the "mystique of Socialism" or the heartfelt belief in equality and a classless society. Democratic socialism, in fact, was based on these principles.

Throughout Homage to Catalonia Orwell described the Spanish working class as decent and generous. He based these assertions only on what he saw during his year in Catalonia. He had ascribed similar traits to other working-class populations before. "A Spaniard's generosity, in the ordinary sense of the word, is at times almost embarrassing. If you ask him for a cigarette he will force the whole packet upon you." ${ }^{141} \mathrm{He}$ later recounted his stint in a Spanish hospital after being shot in the throat when he happened across two comrades from P.O.U.M. that were actually at the hospital visiting someone else. Realizing that Orwell was without tobacco, they gave him a week's supply. Only later did Orwell realize that there were no more tobacco supplies available when they gave him the last of their tobacco.

The decency of the Spanish working class rested on a simple view of life. For instance, Orwell pointed out that in the trenches what mattered most was firewood to keep warm, followed by food, tobacco, candles, and lastly the enemy. ${ }^{142}$ The Spanish working class had not yet been spoiled with material luxuries. Nor were the Spanish contemptuous of outsiders (neither the British nor the French), though Orwell failed to mention that 
the Spanish were fighting for their lives and needed all the help they could get. They therefore naturally accepted Orwell as their equal.

He often derived more from every day scenes than met the eye. He described the building of a barricade. "With the kind of passionate energy that Spaniards display when they have definitely decided to begin upon any job of work, long lines of men, women, and quite small children were tearing up the cobblestones, hauling them along in a hand-cart that had been found somewhere, and staggering to and fro under heavy sacks of sand." 143 The benevolence of the low-ranking Spanish Communist troops was the reason why Orwell and his wife were not arrested during a twohour search of their hotel room. The troops would not look between the mattress or under the bed for incriminating documents because his wife was in bed the whole while. "[O]bviously there might have been half a dozen sub-machine-guns under the mattress not to mention a library of Trotskyist documents under the pillow...[T]hese men were probably Communist Party members themselves. But they were also Spaniards, and to turn a woman out of bed was a little too much for them." ${ }^{144}$ At other times, Orwell bordered on sounding ridiculous, such as when he described the Spanish working class as, "...a species of nobility" and a throwback to an earlier, more pure age. ${ }^{145}$ Orwell admitted that Spain had had a hold on his imagination even before he arrived. Images of bullfighting, olive trees, fine wines and women in black mantillas filled his mind. ${ }^{146}$ These preconceived notions of the Spanish, coupled with his bloated perception of the northern British working class and other exploited populations, must have only accentuated what he saw. 
The press coverage of the Spanish Civil War was not an honest portrayal of the facts, rather it was a propaganda tool of the political parties on both the right and left. The press in government-controlled regions claimed that the Communist attempt to rid the government of the anarchists and other "non-Moscow" leftists was the suppression of an attempted coup led by P.O.U.M. Orwell carefully proved why this could never be the truth. For one, P.O.U.M. was the smallest of the three groups biding for power. In truth, it held irreconcilable ideological differences with the Communists. The press reported that the street fighting (which the Communists had actually initiated) was meant by P.O.U.M. to create disorder so to weaken the government. P.O.U.M. was reported to be a pro-Franco Trotskyist group. ${ }^{147}$ This absurd perversion of the truth - for they were neither Trotskyists nor pro-Franco - was the only version reported in the newspapers.

The coverage of the Spanish Civil War by the British press was no better. The British press blindly accepted the Communist's account of the war, and, in some cases, totally misinterpreted the events. Some British papers reported the uprising not to be a Trotskyist revolt orchestrated by P.O.U.M. but one led by the anarchists. ${ }^{148}$ In other instances the British press was guilty of giving away information to the fascists, such as about P.O.U.M. military strength on the front. ${ }^{149}$ By war's end Orwell had come to the belief that honest press coverage of war was unlikely; he even went as far as saying the two were incompatible. Orwell rationalized that a good part of the British press was hopelessly a pawn to Moscow. What horrified him most about the press coverage of the war was that the 
untrue was accepted by the public as fact. He elaborated on this theme in Nineteen Eighty-Four, but the idea, itself, can be traced to his time in Spain.

The conflict between the Communists and other leftist forces was over ideology. The government forces fighting against Franco were divided into three factions. Although smaller political parties existed, none were large enough to be noted. The smallest group of the three was P.O.U.M., which Orwell described as a dissident revolutionary communist party comprised mainly of the working class and a sprinkling of the middle class. Unlike the Communists, P.O.U.M. drew little support from the bourgeoisie. He summarized their views as: "[b]ourgeois 'democracy' is only another name for capitalism, and so is Fascism; to fight against Fascism on behalf of 'democracy' is to fight against one form of capitalism on behalf of a second which is liable to turn into the first at any moment. The only real alternative to Fascism is workers' control." ${ }^{150}$ Other than P.O.U.M., the only other group that held egalitarian ideas was the anarchists.

In the later stages of the war, P.O.U.M. collaborated with the anarchists or C.N.T.-F.A.I. (C.N.T. or Confederacion Nacional de Trabajadores was a huge block of unions that had as its political organ the F.A.I. or Federacion Anarquista Iberica, an anarchist organization.). The group had broken anarchistic dogma by entering into government positions yet it essentially held to anarchist doctrine. ${ }^{151}$ Orwell said its belief in the revolution and a worker-ran society mirrored that of P.O.U.M. It wanted worker control over industry and government by local committees rather than centralized 
government. The anarchists were the vowed enemy of the bourgeoisie. Its hatred of privilege and injustice was unmatched. It was the anarchists who were responsible for tearing down the Catholic Churches around Spain. Sadly, the Catholic Church had supported Franco. Anarchism, Orwell believed, had ignited a religious fervor in the people. "To the Spanish people, at any rate in Catalonia and Aragon, the Church was a racket pure and simple. And possibly Christian belief was replaced to some extent by Anarchism, whose influence is widely spread and which undoubtedly has a religious tinge." ${ }^{152}$ Orwell similarly hoped to bring a spirituality to democratic socialism. He believed that Protestant morality, along with northern British working-class traditions, would heighten the common person's attachment to democratic socialism.

The largest and most powerful faction in the government were the Communists, or the P.S.U.C. (Partido Socialista Unificado de Catalunya). At the beginning of the war, it had been formed by the fusion of various Marxist parties. By mid-war it was affiliated with the Third International. Once it began receiving arms from Moscow, its stance on the war was sealed. Unlike P.O.U.M. and the anarchists, the Communists believed that Franco must first be defeated before revolutionizing society. Orwell respected this strategy but later doubted its sincerity. The Communists had no plans of reordering society. While the Communists did have some working-class support, it drew a large part of its membership from the small bourgeoisie - the shopkeepers, the officials and the wealthier peasants. The Communists differed from the two groups described above in that it wanted a strong central government, no committees and 
an unified army. ${ }^{153}$ The Communist-led Popular Army reflected the rift between the Communists and the anarchists and P.O.U.M. Whereas the P.O.U.M. militia largely reflected principles of equality, officers in the Popular Army earned higher pay and wore different uniforms than the lower ranks. The Communist relied on bourgeois support and aid from Moscow. The Spanish Communists, like their Soviet counterparts, had repeatedly violated Marxian teachings. Gradually during the war, the Communists stripped away power from the trade unions, forced the surrender of former allied armies and removed all ideological opposition from the government. In a sense the Communists contributed to Franco's victory because they refused to supply the anarchists and other militia forces with arms, which prevented an Aragon offensive. ${ }^{154}$ The Soviets were not revolutionary in Spain; neither had they been in France, which Orwell largely blamed on the Soviet need of French capital. ${ }^{155}$ Once the Spanish Communists gained complete control of the government, class distinctions returned and the bourgeoisie walked freely on the streets. The Barcelona controlled by the Communists that Orwell returned to after fighting in the field starkly contrasted to the one he had seen when he first arrived only months before. The workers were no longer in the saddle. Anarchists and other political dissidents were jailed without trial and workers were stripped of arms. A military police ensured order and political murders were not out of question. To darken matters, communists around the world accepted the lies now coming out of Spain. However, it was not until his life came under danger that Orwell turned completely against all communists. Afterwards, he labeled them to be 
betrayers of the revolution and the party of bourgeois values but he still argued that the fascists were a greater threat to the common person. 
Coming Up for Air

Coming Up for Air, written during 1938 and 1939, was intended to be an instrument to inspire patriotism, to awaken the so-called "dead" from their deep sleep. The autobiographical, central character, George Bowling, was born ten years before Orwell so to place him squarely in the Victorian age, which Orwell had always idealized. George continually recounted the pre-World War I past when it always seemed to be summer and all was peaceful and secure in order to find meaning in his sterile, monotonous existence in the lower-middle-class suburbs which he regarded as inescapable as a future dominated by Hitler. What he found when he returned to his boyhood hometown was not what he had hoped an escape into the living past. The face of the town had changed vastly; it was nearly unrecognizable. He learned from his trip that it was often necessary to go back to the past to find meaning in the present and the future. Though dead, gone and often biased by personalized memories, the past lived on in memories and could be used to understand the present. It could also be used to form an understanding of what was around the next corner. On a different level, it is a novel about class and how it affected perceptions and attitudes. In effect, Orwell was challenging the British lower classes, both the lower-middle and working, to reexamine the bigger picture; otherwise, Hitler would end their way of life.

Orwell fashioned the nostalgic George after the Tory anarchist vein in his thought. He glorified the past, viewed the present as corrupt, and 
looked to the future with horror. George's favorite uncle, Ezekiel, a selfeducated, quick-witted, benevolent intellect, represented the typical nineteenth-century liberal. "He [Uncle Ezekiel] was always denouncing Joe Chamberlain and some gang of people that he referred to as the Park Lane riffraff'. I can hear him now, having one of his arguments with Father. 'Them and their far-flung Empire!'...For a week or after Uncle Ezekiel gave it out that he was a pro-Boer and a Little Englander, they were hardly on speaking terms." 156 George accepted technology as necessary but mourned the fact that it had uprooted the country life of the lower classes in the north. Ever-polluting smoke stacks, stained red-brick buildings, endless suburbs of identical rowhouses (which George sought to escape from) and processed foods were the modern age's byproducts. Even George's secluded boyhood fishing hole had been drained and was being used as a dump. What George realized as he picked flowers from the roadside was that industrialization had financially freed more people than was ever thought possible. Though destroying the landscape, it made possible the free time for people like himself to pick flowers and enjoy nature. Yet, George only bitterly accepted modernity.

He considered the past a purer time. He remembered how his mother used to be amazed after reading a murder story in the press; in the era after World War I, crime had become so common that people did not even blink when they heard about a murder. The Victorians were also more religious than George's contemporaries. "You took it for granted, just as you took the Bible, which you got in big doses in those days." ${ }^{157}$ George 
later said that most Victorians believed in life after death. ${ }^{158}$ The Tory anarchist element in his personality again surfaced when he asserted that Victorians were staunchly anti-militaristic but were patriots at the same time. ${ }^{159}$ Unfortunately, World War I had ushered out the old and brought in the new. The decadence caused by the war, a slumping economy and the realities of capitalism had become omnipresent. By story's end, George resigned himself to the present and regarded the past as merely a contextualizing agent, as a means of clarifying the present and understanding what might happen in the future.

World War I ended the tranquillity of Victorian culture and spurred radicalism. As Bowling put it, "[i]t would be an exaggeration to say that the war turned people into highbrows, but it did turn them into nihilists for the time being. People who in a normal way would have gone through life with about as much tendency to think for themselves as a suet pudding were turned into Boshies just by the war." ${ }^{160}$ Although Orwell made a number of references to intellectuals in Coming Up for Air, two instances stick out. His most in-depth examination of an intellectual would have to be of George's friend, Porteous, a retired public school master with an extensive knowledge of the past, especially the ancients. Porteous seemingly said not to worry about the present because it surely has already happened on a grander scale in the past and time will march on just the same no matter what. A distraught George concluded when Porteous failed to understand the deeper implications of Hitler and Stalin that his friend was hopelessly oblivious to the present, incapable of change and devoid of spirit. Porteous relegated them to minor characters 
in the history of the world. Orwell designed Porteous' character after the English intelligentsia, whom he believed to be mired in theoretical abstractions and the worship of Moscow. They, too, failed to understand the deeper implications of their actions. An anti-fascist speaker at a Left Book Club meeting made up the other notable scene on intellectuals. The speaker tried to sway the audience to his pro-war stance by stirring up hatred against Hitler with an array of slogans. When George looked inside the speaker's eyes, he visualized sadistic imagery, which upset him and had to do with Orwell's belief that most intellectuals would basically overstep the bounds of decency to get their way. Others in the crowd included a run-of-the-mill Labour Party official, who, it was said, had talked of change for years but who had never done anything; a Trotskyite, who was "a smart Jew", but obviously not the type to live up to his high-minded principles; and three communists, obviously young Russophiles, caught up in "dialectical materialism and what Lenin said in 1918." ${ }^{161}$

Like many other Orwellian novels, the class question played an integral role in Coming Up for Air. George's unsatisfactory marriage to Hilda largely stemmed from his inability to understand her background. She came from a long line of military, professional, and official classes; her family's status had slipped between wars to that of the "lower-upper middle class." Landless and without the financial means to regain entry into the upper-middle class, Hilda's family clung to their aristocratic heritage. The family's household had reminded George of an imperial household from the "eighties." George does not realize until later that the 
family would never rebound into the world of the living, yet, at first, George admired the aristocratic touch that Hilda brought to his life. Little did he realize how it was necessary for the penniless Hilda to latch on to the first man who came along. In fact, Hilda's family also misunderstood George's status. They believed him to be firmly in the middle part of the middle class, an up-and-coming professional.

George, on the other hand, had come from more modest roots. His father had owned a small town seed store. Like other boys from the lower-middle class, George was pulled out of the second-rate school at sixteen to help with family finances, which had begun to dwindle after World War I, due mainly to the arrival of an all-purpose chain store. He claimed there was class distinctions even inside the lower-middle class between the shopkeepers' sons and those of laborers and farm hands. ${ }^{162}$ When during the war he served along side the upper class, George said, "...they never really get over that frightful drilling they go through at public schools."163 George's work as an insurance salesman in which he made five pounds a week was financially a small step forward compared to his father's struggles as a shopkeeper, yet he regarded selling insurance as largely a swindle. Being a part of the capitalistic monster did not raise his status above his father's, and it certainly left no opportunity to climb out of the lower-middle class. George described himself and other members of the lower-middle class as being respectable householders - "that's to say Tories, yes-men, and bumsuckers." It is this banal existence that he tried to escape. ${ }^{164}$ By story's end, George had gained consciousness of the 
situation at hand. Orwell hoped that others from the lower-middle class would do the same.

George and Hilda continually quibbled over finances mainly because the fixed income that Hilda's family lived on had forced them to pinch pennies. She continually accused George of trying to live above his means, which was common to those raised in lower-middle class homes. George had always aspired to be like the professional classes, yet a lower-level insurance job never afforded him that kind of status. On the trip to his former hometown, he used gambling winnings that he had hidden from Hilda to finance it; all during it, he pretended to be a stockbroker. He spent the whole pot on a nice hotel, drinking and chasing women, while trying to piece together the past. At various times he made reference to the happy-go-lucky attitude of the proletariat. $\mathrm{He}$, too, was most happy and free on rare occasions, such as the trip, when he acted spontaneously. Although glad not to be a part of the working class (though he made only slightly more money than the average proletariat), he admired the way the working class tried to live life to its fullest on meager wages. He regarded the working class as not only the most decent and alive of all the class but also as the most ignorant concerning things outside its narrow range of experiences. In the end, George is forced back into the present, into the day-to-day drudgery of breadwinner. Now enlightened, he could face his present responsibilities with wisdom from the past. He hoped that his countrymen would also wake up to the threat of Hitler. Until then, he would lead the same day-to-day life. 
Orwell left it unclear whether England would wake up. After all, the working class devoted all its energy to getting by; the intellectuals were caught up in useless, even harmful abstractions; and the upper classes fought for the status quo, which precluded an enlightened public, because an enlightened public threatened its power. The upper class was simply incompetent and lazy. Orwell placed his hope for democratic socialism in people like George, those from the lower-middle class who made just enough to relate to the commoner's woes and who had just enough education to fathom the past, present and future for what they actually were. How this class would spread this knowledge to the other classes he left unanswered in Coming Up for Air. George lamented the strong possibility of a future dominated by Hitler and Stalin types, "There's no escape. Fight against it if you like, or look the other way and pretend not to notice, or grab your spanner and rush out to do a bit of face-smashing along with the others. But there's no way out. It's just something that's got to happen." ${ }^{165}$ 
Animal Farm

The highly controversial Animal Farm was first published in 1945 by Martin Secker \& Warburg, Ltd., after being passed over by several large publishing houses due to its anti-Soviet content. However, it was more than an attack on Stalinism; it demonstrated that collectivization brought with it certain dangers, such as the destruction of intellectual liberty and traditional culture. Orwell agreed with Marx that human history could begin once the revolution ended. In no way did he think that a perfect society would be created overnight. During World War II, Communist Party membership across western Europe rose sharply, largely because left-wing intellectuals in Britain and other western European countries increasingly romanticized life under Stalin. Orwell attacked the accounts of the Webbs and others who went to Moscow. In Spain Orwell had witnessed first hand the anti-revolutionary politics of Stalin; moreover, he noticed before others Stalin's blatant disregard for democracy. In Animal Farm, he exposed the brutality and unjust nature of the thirties purges. He also exposed the falsity of the alleged Soviet technological paradise. He believed that the British Russophiles and other European communists had fallen prey to Soviet propaganda. He understood before other intellectuals that the Soviet Union was in no way classless. In fact, bourgeois mannerisms persisted in the Soviet elite. All this is exposed in Animal Farm in the form of a fable. Orwell deserted realism for fable because his other attempts at uprooting these Soviet myths had all failed. Alex Zwerdling rightly reported that Orwell fled from realism because he 
needed the artistic leeway to create a "countermyth" the public would remember. ${ }^{166}$

Major, a pig modeled after Lenin, first incited the other farm animals to revolt when he claimed, reminiscent of Marx, that the life of an animal was "misery and slavery." He said that an animal's labor was always stolen by humans. He proclaimed that once in power the animals were never to resemble man. "All animals were equal" was the battle cry of the revolution. After his death, Napoleon (Stalin) and Snowball (Trotsky), who were both pigs, bided for leadership. It was accepted amongst the animals that the pigs were the smartest animals and so naturally were to assume leadership. The pigs' inherent greed soon showed through in their actions. They hoarded the better foods from the farm and refused to work along side the other animals. They-grew fat and lazy. After Napoleon's self-trained dogs drove Snowball from the farm, all democratic processes forever ended, even though the farm was proclaimed a republic. Although the pigs claimed that equality still existed, they soon justified their own rule by claiming that some animals were more equal than others. Unheard of up until this point, the pigs soon proclaimed that obedience and loyalty were what was really desired in the other animals. Napoleon's rule was at least as harsh as under Mr. Jones, yet the other farm animals complied with his rule because it was generally believed that a new, far greater era had dawned. Napoleon's dogs raised fear and also ensured compliance from the animals. One by one the pigs betrayed the Seven Commandments of Animalism (or communism), which included the prohibition of alcohol, walking on two 
legs and wearing clothes. In the end, the pigs drank, had business dealings with the humans and walked on two legs, which signified their full acceptance of human ways and symbolized the spread of bourgeois manners amongst Soviet party members. Things really were not much better than they had been under Jones. However, at least they were ruled by a fellow animal rather than a human.

To spur revolutionary zeal in the farm animals, Major had promised equality, no matter an animal's breed or intelligence. "All animals are equal" had been the seventh of The Seven Commandments. Orwell portrayed the pigs as inherently greedy, only out for power, not unlike the Soviet ruling elite. The pigs misgauged the true nature of the other animals, too. The lazy cat still tried to coax birds onto its paw, and the dogs naturally hated the rats. Moreover, each breed had its own characteristics, which made absolute equality impossible. For instance, the horse, Boxer, was the hardest worker on the farm; whereas, another horse, Mollie, who loved human contact and bows wrapped in her mane, deserted the animal-run farm for a human one. Thus, the pigs misunderstood the inherent tendencies of each breed. As a result, the farm was not run nearly as efficiently as it could have been. The farm, like the Soviet Union, was not run democratically either. The pigs imposed strict rules on the other animals. They limited freedom of speech. The original teachings of Animalism, similar to how the Soviets abandoned Marx's teachings, had been distorted from the top down.

Animalism promised superior technology which would eventually free the animals from long work days. As in the Soviet Union, these promises 
never came true. The windmill epitomized the problems with collectivizing an economy and proved that a Wellsian paradise was not as feasible as had been projected. The painstaking labor in building the windmill went for not when it fell over because its walls were too thin. The windmill was rebuilt but was knocked over by rival farmers soon after completion. Even while up, the second windmill never lived up to billing and did not create less work for the animals. The aging Boxer was crippled while building these windmills. He was rewarded by being hauled off to the glue factory. It is not surprising solidarity and revolutionary zeal quickly evaporated on the farm since work days were no shorter and the standard of living had not risen as the pigs had claimed. By juxtaposing reality with the pigs' claims, Orwell exposed the true nature of life in the Soviet Union.

Even though life was not much different under the pigs as under Mr. Jones, overall, the revolution had not been a total failure. The animals were no longer ruled by a human. Yet, the future did not look all that positive. The pigs, like the Soviet ruling elite, were continually plotting ways to suppress the other animals' opposition. Napoleon's dogs had successfully quieted most opposition. Reminders of the revolution were marginalized or in some cases made illegal. The revolutionary promises of equality and bravery had been replaced by the pigs with loyalty and obedience. ${ }^{167}$ For instance, popular songs from the revolution promoting equality and bravery were no longer allowed to be sung. The pigs ruled with a harshness and a brutality not unlike the humans. If life was now better, it was only slightly better. 
Like in the Soviet Union, the revolution had not erased class distinctions. The pigs, who represented the Soviet ruling elite, even gave their children special status, educating them separately. A committee of pigs, with a central leader - who for throughout most of the fable was Napoleon - made most of the decisions. The pigs were given special privileges, such as the best foods, farmhouse beds and exemption from work. The other animals were classed according to their ability to work. Thus, a bird was considered lower ranking than a dog or horse. Any animal that was believed to be a threat to the pigs' rule was eliminated.

Boxer and Clover, both horses, symbolized the working class. Boxer's personal motto, "I will work harder" demonstrated the horses' unquestioning loyalty; however, like the British working class, the horses were not the most logical or intelligent animals on the farm. "These two had great difficulty in thinking anything out for themselves, but having once accepted the pigs as their teachers, they absorbed everything that they were told, and passed it on to the other animals by simple arguments." ${ }^{168}$ However, the survival of the farm rested on the horses' backs. Neither should the importance of the other animals' work be underestimated. Every animal worked and risked its life to protect the farm from the humans.

The pigs rewrote history to solidify their rule. All disasters and misfortunes, such as when the windmill fell, were blamed on Snowball. "Every night, it was said, he came creeping in under cover of darkness and performed all kinds of mischief. He stole the corn, he upset the milkpails, he broke the eggs, he trampled the seedbeds, he gnawed the bark 
off the fruit trees. Whenever anything went wrong, it became usual to attribute it to Snowball." ${ }^{169}$ It was even claimed that he had formed a secret alliance with a nearby farmer and had actually been aiding Mr. Jones from the beginning. Documents and numbers could prove this and anything else the pigs chose to distort. For instance, it was documented and believed, as in the Soviet Union, that the standard of living had risen. The pigs continually broke tenants of Animalism. Since the pigs were the only animals able to read, they often altered the fine print of Party doctrine to vindicate themselves. By story's end, Party doctrine emphasized obedience and loyalty rather than equality and bravery. The dogs further insured the continuance of Napoleon's rule. In the same way, Stalin had masterfully disguised a police state.

Animalism, like communism, precluded the possibility of religion. As a result, the pigs used propaganda to create the cult of Napoleon. Napoleon was portrayed to the animals as heroic, fearless and intelligent, similar to how Hitler and Stalin were portrayed to their peoples. In effect, propaganda raised Napoleon's status to a supernatural being. Animalism, even in its distorted version, had become religion for the animals. For example, Boxer, the hardest worker and a fearless defender of Animalism, never questioned the pigs' rule and made working for "the cause" his sole purpose in life. His patriotic zeal, although blind to the realities of life under the pigs, bordered on religious fervor and thus allowed him to die happily. Napoleon purposely changed his own status through propaganda techniques from mere animal leader to infallible immortal. He no longer acted the part of an animal. Instead, he created a 
mystique about himself by staying aloof, even eating alone. His dogs followed him around making him appear invincible. A black cockerel let out a "cock-a-doodle-doo" before he spoke. Guns were shot off annually on his birthday. He was referred to as "our Leader, Comrade Napoleon" and "Father of All Animals", among other things. "In his speech, Squealer would talk with tears rolling down his cheeks of Napoleon's wisdom and goodness, and the deep love he bore to all animals everywhere, even and especially the unhappy animals who still lived in ignorance and slavery on other farms." ${ }^{170}$ It had become the norm to give Napoleon the credit for anything positive that happened on the farm. Poems and songs, such as Minimus' poem that was inscribed on the barn walls next to the Seven Commandments, eulogized Napoleon. ${ }^{171}$ In these ways, religious energy had been transferred to worship of Napoleon. 


\section{Nineteen Eighty-Four}

Orwell attempted to show in Nineteen Eighty-Four, published in 1949, how the ideas of socialism can easily be twisted into a totalitarian system. As in Animal Farm, Orwell sought to destroy the myth of greatness that intellectuals had attributed to the Soviet political system. He found little difference between the regimes commanded by Stalin and Hitler. In Nineteen Eighty-Four he made many references to both men. The oligarchical government of Oceania had constructed a nearly infallible system. By taking into account the laws of human nature and the lessons of history, the system discouraged the upper classes (which in the past had most often been responsible for inciting the lower classes to revolutions) from revolting. Various mechanisms, including high-tech surveillance equipment and thought-control devices, controlled every aspect of life of the Inner and Outer parties' members. Although the proletariat or "proles" made up eighty-five percent of the population, they held no political power. The system entrapped them. They were purposely segregated from civilized society and left uneducated. Their standard of living was kept at subsistent levels. Corner pubs and phony lotteries pacified them. They did, however, live relatively free from government control. Hope for revolution did still lie with the proles, but in Oceania the prospects of the proletariat gaining a political consciousness were dim. However, it should be remembered that Nineteen Eighty-Four was not intended to be a prophesy; rather, it was intended to shock the public into acknowledging what could happen after collectivization. 
The Tory anarchist vein in Orwell surfaced in many ways in Nineteen Eighty-Four. Winston continually acknowledged the importance of the past, often making nostalgic references to it. Big Brother had erased the past, for as the Party slogan went, "[w]ho controls the past controls the future: who controls the present controls the past." ${ }^{172}$ History was reshaped to fit the Inner Party's needs. The Inner and Outer parties continually worked to destroy cultures and traditions from before the revolution to increase adherence to Party doctrine. Winston, who worked at a party press altering the past to fit the Party's present claims, realized how the Party had reconstructed the past. He wondered how life had been before the revolution. He glorified what bits and pieces of his childhood and of his parents' lives he could remember. Winston's interview of an old prole at a pub proved to him that although the proles were too ignorant and uneducated to remember individual events from the past, certain primitive emotions innate to humans still persisted in them. ${ }^{173}$ Only in prole quarters did the past (pre-revolutionary society) survive. The past survived in folk songs and by way of human emotion, which had been redirected into state worship in the upper classes. Winston's search to learn about the past led him to Mr. Charrington's antique shop where he illegally bought a few olden trinkets. "If it [the past] survives anywhere, it's in a few solid objects with no words attached to them." ${ }^{174}$

Orwell emphasized in Nineteen Eighty-Four with the creation of Newspeak that effective political writings were simple and straight forward. Newspeak was an instrument used to narrow the English 
language so to narrow the range of thought. It was believed that in time thought would be limited to Party teachings, because potentially unorthodox words were being eliminated. While Newspeak exaggerated the idea that totalitarian regimes destroyed intellectual freedom, it also proved the effectiveness of simple, straight-forward messages.

In Nineteen Eighty-Four, Orwell portrayed an oligarchical regime that was not interested in material gain but was solely after power for power's sake. 'Although the ruling elite called themselves socialists, they had no real intention of creating a classless society based on equality. They were totalitarians who understood and had improved upon the methods of rule used by Stalin and Hitler. Inner Party intellectuals had created an infallible system that perpetuated their own power. Adherence to Party teachings, and not hereditary privilege or wealth, determined who held power. The Inner Party often used socialist rhetoric to quiet public opinion and mask the true nature of the regime. In fact, the government labeled itself "Ingsoc," which in Newspeak translated to English socialism. Party propaganda claimed that society was based on equality and that the standard of living was improving. These lies were perpetuated with thought control devices; by altering the past; by perpetuating myths; and by continually using excess resources in planned wars against other totalitarian powers so that no individual would ever grow rich, complacent or power hungry. The Inner Party was comprised of the same lowermiddle class technicians that James Burnham had predicted would rise and that Orwell had once believed would lead the working class to revolution. 
Traditional religions were incompatible with Ingsoc in much the same way they were with Communism. The Inner Party believed religion would hinder adherence to Party teachings. Consequently, it devised the nonexistent figurehead of Big Brother, who, in Inner Party propaganda, looked like Stalin. It was popularly believed that Big Brother had everybody's best interest. A mystique surrounded him, not dissimilar to a religious figure. Similar to in Nazi Germany and Stalinist Russia, leader worship was rampant. The rhetoric of Big Brother appealed to the primitive side of Party members. Big Brother called the nation to duty; it was heroic to take part and work for a better society. It was no wonder the German masses had been seduced, nor was it shocking to Orwell that British left-wing intellectuals had bought into the myth of the Soviet Union. The worship of political ideologies was an inevitable result of the spiritual black hole caused by modernity. Winston learned about such Party secrets in the supposedly revolutionary pamphlet "The Theory and Practice of Oligarchical Collectivism" by Emmanuel Goldstein. In truth and unbeknownst to Winston, Goldstein's revolutionary pamphlet was actually an Inner Party tool to sniff out revolutionaries. However, it did adequately explain Party ideology, from the psychological benefits of war to the creation of Big Brother. After reading through the pamphlet, Winston still wondered "why" such a system was ever created. While being tortured, O'Brien answered this question by explaining that the ruling elite had never before enjoyed a sense of permanence. It was the prospects of permanent power that motivated them. 
Goldstein's pamphlet explained that three classes - a ruling, a middle and a working - were what comprised every society. Naturally, the middle had always strived to be in power. Only when the upper class governed inefficiently or lost faith in its ability to rule could the middle rise. When successful in capturing power, the middle had always enlisted the lower class on its side by claiming it was fighting for the principles of liberty and justice. As soon as the middle class came to power, the low were thrust back into the all too familiar position of servitude. The low, Goldstein explained, were, in general, "...too much crushed by drudgery to be more than intermittently conscious of anything outside their daily lives." ${ }^{175}$ In Oceania the ruling class had successfully tricked the masses into believing it stood for socialist principles that in the past had been a rallying cry. Once in power they made petty concessions to the proles to pacify them and to prevent insurrections.

The working class had been relegated to a subsistent lifestyle. Similar to how the British upper class regarded all working-class populations, it was taught that the proles were "natural inferiors" who must be kept in subjection. The system forced the working class to live at subsistent levels. The drudgery of day-to-day existence was eased with government-sponsored lotteries and pubs on every corner. The proletariat was segregated from the rest of society in order to remove the possibility of class envy. Yet, Orwell celebrated the prole work ethic. "They were born, they grew up in the gutters, they went to work at twelve, they passed through a brief blossoming-period of beauty and sexual desire, they married at twenty, they were middle-aged at thirty, they died, 
for the most part, at sixty. ${ }^{176}$ Orwell often found beauty in the simplicity of working-class life. For instance, Winston found beauty in an older prole woman singing gleefully in the streets, even though her wrinkled face and robust body showed the marks of a hard life. ${ }^{177}$ What Winston admired most about the proles was the fact that they were the only class whose thoughts and emotions had not been fully conquered by the state, they were still loyal to one another. They were the only class to remain human. Even in the nightmarish land of Oceania, Orwell rested his hope for change in the proles. "The proles were immortal, you could not doubt it when you looked at that valiant figure in the yard. In the end their awakening would come."178

The new ruling elite, fashioned after Burnham's conception of the segment of the lower-middle class made up of technicians and specialists, held a cynical interpretation of human nature and attempted to portray inequality as an unchangeable maxim of life. "These people, whose origins lay in the salaried middle class and the upper grades of the working class, had been shaped and brought together by the barren world of monopoly industry and centralized government. As compared with their opposite numbers in past ages, they were less avaricious, less tempted by luxury, hungrier for pure power, and, above all, more conscious of what they were doing and more intent on crushing opposition." 179 The Inner Party, like the Soviet elite, understood basic human needs and thus created a system that kept all segments of the population pacified. For example, patriotic fervor was induced by reclaiming the excess energy that resulted from the suppression of sex. 
Altering the past to fit Party needs also ensured compliance. The chances of revolution from within were lessened by the abolition of private property. The ruling elite understood that technology had made possible material and social equality but also knew that equality was contrary to its aims. It wanted to stop progress and history at a precise moment and thus fixate itself in power forever. ${ }^{180}$ In these ways the ruling class had procured power and made revolution highly unlikely.

The Inner Party utilized various modes of illusion to bolster support. Goldstein concluded that all the "...beliefs, habits, tastes, emotions, and mental habits" of modern life were wrapped into Party ideology. Party intellectuals used these to maintain the mystique of the Party and to obscure the true nature of reality. ${ }^{181}$ Statistics and records verified these illusions. Party propaganda claimed, as it had in the Soviet Union, that conditions were continually improving, even though there was always a tight system of rations. ${ }^{182}$ Throughout his later writings, Orwell sought to destroy the myth that the Soviet Union was rapidly becoming a technological leader.

The ideal set up by the Party was something huge, terrible, and glittering - a world of steel and concrete, of monstrous machines and terrifying weapons - a nation of warriors and fanatics, marching forward in perfect unity, all thinking the same thoughts and shouting the same slogans, perpetually working, fighting, triumphing, persecuting - three million people all with the same face. The reality was decaying, dingy cities where under-fed people shuffled to and fro in leaky shoes, in patched-up nineteenth-century houses that smelt always of cabbage and bad lavatories. ${ }^{183}$ 
As has been shown, propaganda made Big Brother into a cult figure arid perpetuated the belief that Ingsoc was a socialist society. Propaganda also hid many seemingly blatant contradictions in Oceanian society.

The mind exercise of doublethink allowed Party members to hold contrary ideas without tension and thus helped to maintain the illogical nature of Party teachings. Government departments, such as the Ministry of Plenty, which concerned itself with making war, were further examples of ways in which atrocities and injustices were masked. Other ways in which the government hid its true intentions were more subtle. All Party members dressed in overalls modeled after those worn by manual workers in the past. It was believed that this would inspire productivity. Party rhetoric also attempted to link traditional familial values with the regime. In truth, Ingsoc undermined traditional features of family life. Big Brother came before a spouse, parent or child. Sex was monitored, and love was a myth. Yet, the name "Big Brother" was chosen to make society believe he was a family member looking out for its best interest. Other oxymorons included the three slogans, which were "War is Peace"; "Freedom is Slavery"; and "Ignorance is Slavery." 
Conclusion

The same themes again and again occur in Orwell's fiction and documentaries. Each work, in one way or another, dealt with the issue of class. The maturation of this idea grew with each work yet its basic outlines were already in place in Down and Out in London and Paris and Burmese Days. In these early works, Orwell relied more on an innate tendency to sympathize with the lower class than on actual facts. In The Road to Wigan Pier, Orwell went beyond his earlier, sometimes narrow descriptions of exploited populations to give an in-depth analysis of the northern British working class. While giving a fuller account of a workingclass life, his descriptions were often exaggerated, even heavy-handed. This work can be said to be the birth of the myth of the northern British working class, an idea that he later articulated more fully in essays and journal articles such as the "The Lion and the Unicorn" and "The English People." Not all of these longer works were about the working class. Keep the Aspidistra Flying and Coming Up for Air were based on lowermiddle class characters, who, fed up with their own lives, discovered that much of their malcontent could be traced to limitations in the "system." Orwell attempted to show the lower-middle class the advantages of democratic socialism by proving to it that its interests were not all that different from the working class's. In these texts Orwell also spent a considerable amount of time criticizing other left-wing intellectuals and the ideologies they espoused. His most fervent attacks - at least against Soviet Communism - came following his return from Spain in Animal 
Farm and Nineteen Eighty-Four. To a lesser degree and oftentimes more subtlety, the Tory anarchist strain in Orwell (as mentioned in Chapter I) can be found in these texts. Only by understanding the significance of these three themes can a full comprehension of Orwellian socialism be gained. 
Chapter III

Introduction

Orwell constructed democratic socialism around the premise that the northern British working class held specific characteristics. Some of these characteristics, such as decency and generosity, could be traced to all working-class populations. Other characteristics, as we shall see, were specific to northern British working-class culture. By constructing such a culture and because the success of Orwellian socialism rested on its construction, Orwell can be said to have created a political myth - the myth of the northern British working class. Orwell had criticized Sorel for exactly the same thing. Sorel had claimed the myth of the general strike was needed to inspire the French proletariat to action. Before discussing these two figures and the nature of their "myths," it is important to show a few of the many ways in which myth has been defined. In Cosmos and History: The Myth of the Eternal Return, Mircea Eliade gives an anthropological analysis of the meaning of myths and rituals in archaic societies. Vital experiences, such as hunting and farming, were immortalized in myths and rituals, which not only acknowledged a society's mythical beginnings but also reinforced patterns of behavior essential for survival. In effect, myths and rituals were used by early 
societies to give meaning to otherwise "profane" existences. Ian Barbour's Myths, Models and Paradigms provides a philosophical description of the role of myth. He contends that because scientific research is based on humanly constructed paradigms it is nearly as subjective as a religion's claim to truth. He then goes on to say that myths, especially those of a religious nature, provide an invaluable function: they provide an individual with a psychological defense for experiences outside human (which implies science's) understanding. 
A Methodological Survey of Myths

In Cosmos and History: The Myth of the Eternal Return, Eliade describes the role that myths played in archaic societies. Rituals, rites and symbols recreated the primordial act, usually the act of creation. The elaborate systems of interrelated rituals, rites and symbols, which were prevalent in most archaic societies and that centered around gods, ancient heroes, or some other form of mythical ancestry are what Eliade refers to as "archetypes." This system of belief and behavior reinforced group cohesion, protecting it from radical change. In effect, the use of myth and ritual continually reinforced society's very infrastructure. Rituals, rites and symbols went beyond the recreation of the mythical "beginnings" to embrace hunting and farming, sexuality, and war. These vital activities were constructed in such a way so to further support the original primordial act. ${ }^{184}$ It was believed that reality was found only in these lifegiving experiences, while all other experience was determined to be unimportant, even profane.

By repeating the cosmogonic act, concrete time was suspended (if just for a while) and replaced by mythical time. In archaic societies there was "...a conception of the end and the beginning of a temporal period, based on the observation of biocosmic rhythms and forming part of a larger system - the system of periodic purifications (cf. purges, fasting, confession of sins, etc.). ${ }^{185}$ On these occasions societies attempted to purify themselves by returning to the time of the primordial act when all was pure and new. By turning back the clock, the dead might be 
regenerated. New Year was commonly celebrated several times a year. For instance, agricultural societies might only return to their beginnings when various crops ripened at different times during the year, while other societies might return during marriage ceremonies, the birth of a child, or the inauguration of a new ruler. ${ }^{186}$ It was common in more advanced, socalled "historical" societies, such as the Egyptians, Babylonians, Iranians or Hebrews, to celebrate the New Year based on solar and lunar measurements of 360 days. ${ }^{187}$ The Judeo-Christian tradition differed from these others in that many of its myths can be traced to actual points in time. Also, history could only truly be abolished when Christ returned to the earth at some point in the future. ${ }^{188}$ What is important to remember, however, is that each of these societies attempted to return to its mythical roots on vital occasions or planned to do so at some point in the future. Historical time was thus negated, even in the Judeo-Christian tradition.

The transformation of historical personages into mythical figures occurred over a relatively short period of time and is another example of how archaic societies reaffirmed archetypes and maintained order. The transformation involved altering historical facts to fit into the existing archetype. No events were wholly unique. Fact was often turned into myth in as little as two or three centuries. "The historical personage is assimilated to his mythical model (hero, etc.), while the event is identified with the category of mythical actions (fight with a monster..., etc.)." ${ }^{189}$ Time was viewed in archaic societies as well as by more advanced, early civilizations, such as the Greeks, as circular. Plato made such claims, and from Imperial Rome onward, Christian and pagan alike have been 
influenced by Polybius' conception of cyclical time. According to J.G.A. Pocock, most Imperial Romans believed that governments began as virtuous monarchies and by the end of this cycle ended in corrupt anarchies. Imperial Romans glorified the Republic and increasingly viewed themselves as corrupt. They divided history into different epics; each successive generation fell further away from virtue and the idealized Republic. Christians, too, have always viewed civilization in a continual decline. They believe that humans will eventually destroy the Earth and only God will restore it. The circular conception of time has been challenged in modern times by science and philosophy. Modern philosophies, such as Marxism, accept a secular, linear history (Marxists view history as a series of dialectics leading to the great proletariat revolution.). The dominant philosophy in the modern world - science asserts that man is continually progressing forward. Even science has been challenged in recent years by the postmodernists. History's ultimate meaning is undecided.

In Myths, Models and Paradigms, Barbour contends that scientific study is not quite as objective as once thought. Scientific research is based on humanly constructed paradigms. According to Thomas Kuhn, scientific paradigms are discourses of accepted beliefs that directly effect what is investigated. Although scientific paradigms assume a rationalistic language, they are subjective, not so different from the religious paradigm.

Scientific models are products of creative analogical imagination. Data are theory-laden; comprehensive theories are resistant to falsification; and there are no rules for paradigm choice. To be 
sure, each of these subjective features is more prominent in religion; there is a greater diversity of models, greater influence of interpretation on data, greater tenacity in commitment to paradigms, and greater ambiguity in paradigm choice. But in each of these features I see a difference of degree between science and religion rather than an absolute contrast. ${ }^{190}$

Moreover, the objectivity of scientific paradigms comes increasingly under scrutiny when viewed historically. They have continually been altered over time, reacting to different variables out of historic necessity. Scientific, as well as religious, paradigms have time and time again been encompassed by newer ones, transforming existing beliefs into new formations. Therefore, Barbour contends that both science and religion are subjective entities open to interpretation that function similarly, though for different purposes. He adds that religious paradigms might stand to gain by instilling a more rationalized, "scientific" language. ${ }^{191}$

Religious language contains a non-cognitive entity not found in scientific language. Like Eliade, whose work he praises, Barbour sees great relevance in the importance of myths, especially religious ones. Myths provide five different functions: they offer ways of ordering experience; they inform individuals about themselves and link them to their community; they are personal and give lives meaning; they provide a concrete code of morality to be emulated, not some theoretical ideal impossible to repeat; and they are enacted not only in symbolic words but in rituals. ${ }^{192}$ Myths provide the individual with a psychological defense for experiences outside the individual's, as well as science's, realm of 
understanding. It is now widely accepted that science cannot provide every human need, such as the irrational, spiritual component, which seemingly has always been a psychological necessity for a certain percentage of every society's population.

While both writers used "myth" for different purposes, each described it in similar terms. Each implied that myths prompt subjective beliefs that culminate in changes in behavior. Sorel defined myth in somewhat similar terms. Sorel's myth rested on the belief that the bourgeoisie's influence would inevitably cause a general strike at an undetermined point in the future. Orwell attacked him for his advocacy of political myths yet Orwell, himself, had unknowingly created a political myth of his own. Orwell's hopes for democratic socialism rested on characteristics that he ascribed not only to the northern British working class but to the other British classes as well. 
Onwell's Attacks on Sorel

Sorel is widely known as a radical at the turn of the century who advocated the use of a political myth to rally the proletariat to revolt. In Sorel's principle work, Reflections on Violence, he claimed that in order for a social or political movement to bring about catastrophic change it must first create a vision in the proletariat not unlike that of the great religions. A leader in the French syndicalist movement for many years, he claimed when the proletariat believed wholeheartedly in the probable outcome of the myth of the general strike that it would occur. Sorel believed that a simultaneous strike of all trade unions naturally appealed to the proletariat's innate desire to be free of bourgeois influence (The proletariat would not be prompted by class envy or materialism as Marx had claimed.). He considered it a practical plan: it would undoubtedly force the bourgeois government to take action, which would probably transform the strike into a struggle for power.

As Alex Zwerdling noted, Orwell attacked Sorel for claiming that it was necessary for political movements not to set realistic goals but to "...inspire a faith comparable to the ideal visions of the great religions." He claimed that Sorel's myth of a general strike represented an utopian vision, and it was utopianism that had undermined the socialist movement because it withheld the true nature of socialism from the masses. ${ }^{193}$ Orwell believed that most utopians, including Sorel, were at heart pessimists, who had resorted to far-fetched utopian visions because they believed that human progress was impossible and 
therefore society could never be improved. Orwell attacked Sorel and other utopians in a December 1943 Tribune article. "The answer, which ought to be uttered more loudly than it usually is, is that Socialism is not perfectionist, perhaps not even hedonistic. Socialists don't claim to be able to make the world perfect: they claim to be able to make it better."194 For socialism to gain widespread acceptance by the proletariat, Orwell thought that socialists must present socialism in a more honest and realistic manner. Left-wing intellectuals were turning socialism into a religion to fulfill their own spiritual voids left by the refutation of patriotism and traditional religion; it was no longer a movement for the people. ${ }^{195}$ These attacks on Sorel shed light on what Orwell perceived to be "illusion" or "myth." Ironically, in spite of these attacks on Sorel and other left-wing intellectuals, Orwell, too, had unknowingly created a political myth of his own - the myth of the northern British working class.

Sorel was above all a moralist. He believed that he was living in a corrupt age in which the bourgeoisie ruthlessly exploited the working class. Sorel claimed that bourgeois culture, characterized by materialism, greed, and a deterioration in family and sexual morality, had begun to taint the working-class. Yet a good part of the working class still practiced a brand of morality that was not so unlike purer, past ages. The natural elite of the working class were generally craftsmen and technicians, who, since they were creators, had an implicit understanding of the true nature of society. Sorel believed that the myth of the general strike had to contain propaganda about the decadence of bourgeois culture and the necessity of a "ricorso," which was the cyclical return to a forgotten, primitive morality 
that Giambattista Vico, who Sorel had read and admired, had called for during the Italian renaissance. ${ }^{196}$ Only then would the myth be strong enough to prompt the working class to overthrow the bourgeoisie. Sorel correlated virtue with family and sexual morality. This morality was not unlike the tribal societies envisioned by anarchists or that practiced by the early Christians who had not yet been corrupted by organized religion. "The values to which the contemporary world clings most closely, and which it considers the true ethical values, are not realized in convents, but in the family; respect for the human person, sexual fidelity and devotion to the weak, constitute the elements of morality of which all high-minded men are proud. ${ }^{" 197} \mathrm{H}$. Stuart Hughes even describes this morality as being "prudish", which is accurate considering the great emphasis that Sorel placed on sexual chastity. ${ }^{198}$ To be successful, the general strike would be led by a natural class of heroes, who would follow historic instances of individual greatness, heroism, generosity and dignity. Stealing heavily from Friedrich Nietzsche, Sorel added that these warrior heroes would be obligated to lead their proletarian compatriots by example. Violence was justifiable, so long as it was not out of malice or envy but solely out of want of freedom.

Therefore, Sorel's vision was a reaction against rationalism and modernism. It was instinct that led him to conclude the general strike had a purely natural appeal to the worker. Sorel reasoned that the driving force behind the general strike was the want of a primitive morality; this contrasted sharply with Marx, who saw the revolution as a rational, historical response to unequal material conditions. Leszek Kolakowski 
has summarized the psychological motivations behind the general strike and ricorso. "The mainspring of the revolution is not poverty but class antagonism, and the workers' cause is not that of the poor who want to take away the property of the rich, but that of direct producers who wish to be the organizers of production. The principle values of socialism are those of morality and not of well-being, and it may be noticed that the poorest members of the proletariat are the least, not the most, revolutionary-minded." ${ }^{199}$ Sorel said that Marx, as well as the utopian socialists, failed to understand the importance of irrational elements found in tradition, religion and custom. ${ }^{200}$ Marxism, like other "scientific" doctrines, viewed history solely as building towards a proletarian revolution, while Sorel claimed that to predict the future was impossible, for history was an irrecoverable, complex process. Sorel therefore refused to predict when the general strike would take place and to what ends it would lead. Indeed, Orwell had wrongly labeled Sorel an utopian.

Orwell rightly detected an idealistic thread in Sorel's myth. It required the full belief and participation of the proletariat, which, from Orwell's vantage nearly a half century later, might have seemed far-fetched. However, in his own day, Sorel was regarded as a legitimate threat to the established order. Unlike other utopian visions that Orwell attacked, Sorel's myth did not describe a future society after the general strike or exactly how the worker would destroy the existing order (although Sorel is famous for proposing that the use of violence might be necessary). The myth only prescribed a ricorso and promised that power would be centered in the trade unions or revolutionary syndicates. The mythic 
vision was nothing more than a "...single act of intuitive perception" and should be considered "anti-intellectual" in that it divorced thought from theory, history, even sociology, putting all emphasis on a single act at a single moment. ${ }^{201}$ Sorel's vision was a real moment in the future when the proletariat would strike. Sorel understood that his call for a general strike would be interpreted by some as highly speculative. To counter such interpretations, he explicitly stated that the myth of the general strike could not be dissected, for it was a "motive force," the profound conviction of a group. ${ }^{202}$ Rather than an utopian vision as Orwell had claimed, the general strike was a self-fulfilling prophesy based on intuitive perception.

Ironically, similar to Sorel, Orwell romanticized about preserving the rapidly vanishing values embodied in the northern British worker. The majority of left-wing intellectuals were from the upper classes and had lost sight of the importance of the irrational. He mocked Wells in particular for failing to see the secret of Hitler's success. Hitler had been able to exploit an irrational impulse in the German people by appealing to their sense of patriotism (which Stalin had likewise done) and by rekindling German myths. In short, he had awakened the heroic nature that lied buried in the human consciousness by appealing to the "blood, sweat, and tears" of every German. Both Sorel and Orwell believed the key to creating a viable proletarian movement was by appealing to the working class's "irrational side." Like Sorel, Orwell did not believe material gain would be enough to prompt the working class to revolution. The northern British working class was patriotic and would die to defend its way of life. 
Sorel and Orwell viewed democracy in sharp contrast. Sorel considered democracy an instrument of the bourgeoisie; the ideas of liberty and equality were therefore little more than bourgeois rhetoric to pacify the lower classes. Reforming from within, then, could only end in disappointment. Syndicalism was therefore apolitical. It was up to the revolutionary syndicates to raise the class consciousness by spreading the myth of the general strike. Once in power, the syndicates would not structure a new government after the old one; this form of government necessarily put power in the hands of the elite. The very framework of government created a hierarchy. The sole object of the general strike, then, was to restore the control of production to the proletariat who no longer would have a master. Sorel purposely speculated little about the composition of the future "state." He only said that individual trade unions would have to come together and react to whatever conditions arise. In his own words, Sorel said, "[i]t may be said, too, that the greatest danger which threatens Syndicalism would be an attempt to imitate democracy; it would be better for it to remain content for a time with weak and chaotic organizations rather than it should fall beneath the sway of syndicates which would copy the political forms of the middle class." 203

Orwell continually attacked the left-wing for failing to put forward a democratic movement. Like Sorel, he regarded British democracy 
largely a bourgeois racket, though he did believe the British system was a limited form of democracy since it protected intellectual liberty. True democracy for Orwell would only happen after the working class took power. Unlike Sorel, never did he seek to destroy the general framework of government. Even in 1941 when he called for a social revolution, he merely hoped that the proletariat, led by the lower-middle class, would overthrow and replace the bourgeois government. He soon concluded the revolution to be an impossibility. The British proletariat and the lower-middle class were not ready for catastrophic change. Thereafter, he tried to push reforms from within the Labour Party, even though he still claimed it was far from being a true workingclass party. In "Second Thoughts on James Burnham," he attacked those intellectuals - Sorel, Machiavelli, James Burnham - who claimed that democracy had never existed. ${ }^{204}$ It was thinkers like these who saw progress as an illusion. This was a pessimistic way to view the world, but again was no grounds for Orwell to call Sorel an utopian. 
Orwell and the Myth of the Working Class

Orwell sought to expose other myths as well, such as the belief Wells and other millennialists held that technology would create enough material comfort that class tensions would soon evaporate. In "Wells, Hitler and the World State," Orwell pointed out what Wells had failed to consider: Hitler had used technology to build the Nazi regime into a world power. Wells, as well as the Webbs and other socialists in the Labour Party, had failed to give an accurate portrayal of what an hedonistic brand of socialism truly implied. At the time it meant the Labour Party quietly supported British imperialism because it benefited the British economy. Hedonistic socialism could never win over the full support of the working class; it only had a slight appeal. Intellectuals had underestimated the psychological appeal of a "moralized" form of socialism.

Orwell claimed that many of the political illusions created by intellectuals were actually manifestations of a psychological disease. In "Notes on Nationalism," he referred to patriotism as a devotion to a particular place and way of life. Patriotism fulfilled an important psychological need. Although patriots believed that their ways were best, they in no way wanted to impose them on others. Nationalism resulted as intellectuals declared such "irrational" elements as 
patriotism and traditional religion to be anachronistic. Nationalism was inseparable from a desire for power. Out for competitive prestige and power, nationalist intellectuals deceived and distorted reality to gain adherents. Nationalistic movements included communism, political Catholicism (as seen in G.K. Chesterton), Zionism, and pacifism, among others. Intellectuals during Orwell's day believed truth could only be found within the perimeters of political and religious ideologies. For example, no matter what Stalin did it was still explained as "Marxian," even if that meant justifying political injustice or murder. The British Russophiles, who had transferred patriotism, Protestantism and a host of other British traditions into a worship of Soviet Communism, never bothered to question Stalin's word. In Homage to Catalonia, Orwell attempted to refute the Russophiles' version of the Spanish Civil War.

According to Orwell, it was especially important for socialist writers to remove myths and illusions from the movement and give as clear and accurate a picture as possible. Instead of giving simple, honest accounts, left-wing intellectuals in the thirties had written in a heavy handed, technical jargon. Not only had they mislead and confused the proletariat, they had destroyed the beauty of the English language. Using popular, socio-literary writers, such as Dickens, as his models, Orwell resurrected realism. In "Good Bad Books" Orwell explained that 
he had always admired popular writers because they were able to speak to the average person. After all, it was the people, and not the literary critics, that a serious political writer sought to influence.

Zwerdling claims that Orwell avoided the particular and unique in his novels during the thirties; instead, he wrote about characters and themes in which his audience was sure to relate. ${ }^{205}$ There is a sociological dimension in his early fiction. The use of documentary was also further proof of his devotion to realism. With his labors earning only a small readership and feeling a need to vent his growing frustration in a more artistic manner, Orwell gave up writing realistic novels and documentaries and turned during the forties to the essay and to fantasy. ${ }^{206}$ Such a turn had its rewards, but it also had shortcomings that he failed to foresee.

By the late thirties and early forties, he began to view himself as an historian and pamphleteer whose sole purpose was to alert the general public of what was truly happening around the world. The essay - which before this time he had used only sparingly - allowed him to express his exact feelings. His creativity was no longer stifled by the sociological format of the thirties. In these essays he carefully guarded against becoming a propaganda writer. It is true that he had a political agenda (and one that was ever-changing), yet even the most political of these essays were written in a conversational, simplistic 
manner, which seemingly made them objective. "He tried to perfect a kind of essay that would combine the desire to analyze and reform society with the need to say as an author what one felt as a man. His best essays are personally expressive and yet illuminate the world outside the self. The subjective and objective components in them seem perfectly balanced." 207 Even in his most radical essays - "The Lion and the Unicorn" and "The English People" - he attempted to explain and give justification for his arguments.

The real break from realism came in longer works such as Animal Farm and Nineteen Eighty-Four. Both of these were attempts to expose the proliferation of totalitarian regimes in Russia, Germany, Italy and Spain, during the thirties and forties. Orwell needed a stronger literary form than realism to diagnose the disease that had fully infected intellectuals and was beginning to spread to other segments of the population. Prominent British gradualists, such as the Webbs, were even buying into the myth that the Soviet Union was the ideal socialist commonwealth. Orwell's past essays, novels and documentaries had obviously done little to challenge this powerful myth. Consequently, he turned to fantasy (in the form of a fable) in Animal Farm.

On my return from Spain I thought of exposing the Soviet myth in a story that could be easily understood by almost anyone and which could be translated into other languages. However the actual details of the story did not come to me for some time until one day (I was then living in a small village) I saw a little boy, perhaps ten 
years old, driving a huge cart-horse along a narrow path, whipping it whenever it tried to turn. It struck me that if only such animals became aware of their strength we should have no power over them, and that men exploit animals in much the same way as the rich exploit the proletariat. ${ }^{208}$

In Animal Farm (see review in Chapter II), Orwell exposed the Soviet Union for what it was - a static, hierarchical oligarchy. It was not the industrial power that Russophiles had reported. For similar reasons he turned to dystopian fiction in Nineteen Eighty-Four (see review in Chapter II) to articulate his condemnation of totalitarianism. Oceania was modeled after the Soviet regime to show what could happen in a collectivizing society. Zwerdling right claimed Orwell's flight from realism to fantasy was actually a ratification of Sorel's belief in the necessity of political myth. ${ }^{209}$

In truth, Orwell had already created an elaborate system of myth. The characteristics that Orwell ascribed to each of the British classes explained existing inequalities and rationalized why democratic socialism would soon gain the adherence of the working and lower-middle classes. Each class had specific traits that mainly resulted from socio-historical circumstances (see Chapter I - Orwell's Reaction to the British Class System). Not every trait could be rationally explained, some traits were handed down from generation to generation and class to class. Each class had distinct traits that could only be found in Britain. The natural ruling class, Orwell insisted, was the northern British working class. The mythicization of this class began with the release of The Road to Wigan Pier (see review in Chapter II) in 1936. He had likewise sentimentalized the lives of other exploited populations in his earlier works, but never 
before had he described with such fervor and detail a working-class culture. In "The Lion and the Unicorn" and "The English People," he elaborated on the traits and culture of the northern British working class. It was this culture that was moral and just; it was the northern British working class who were the rightful heirs to power.

In "The Lion and the Unicorn," he claimed that social and historical circumstances had created favorable conditions in the lower classes for a social revolution, all that was needed was a catalyst, which conveniently appeared in the form of the lower-middle class. Honest, straight-forward rhetoric would be needed to win over the lower-middle class. The lowermiddle class, he believed, could easily be won over, for they had more in common, at least in an economical sense, with the working class than with the upper classes. Socialist intellectuals only needed to win over the lower-middle class and with careful propaganda the working class would naturally fall suit. Otherwise, the decay of the ruling class, the failure of the Labour Party to represent the working class, and the conflict of interest that capitalism necessarily created in times of war, would cause a certain defeat in the war against Hitler. He outlined the changes that were most pressing and warned that a social revolution might even lead to bloodshed. "But just because the English sense of national unity has never disintegrated, because patriotism is finally stronger than classhatred, the chances are that the will of the majority will prevail."210 Orwell believed that only the innate qualities of the northern British working class could save the British from defeat. 
Although diverse, the northern British working class were united by British traditions. The northern proletariat especially respected individual liberty, justice, and objective truth. While not Puritans or overly found of organized religion, a Christian piety had remained a fixture in their lives and had protected them from the influence of harmful ideologies. The northern working class had behaved in the past in distinctive ways. Its members had always been anti-militaristic, old-fashioned, instinctual, illogical (for they were overly found of sports and gambling), simple and generous. Above all, its members were patriotic and decent. Although the working class had always been slow to change, its culture had always persevered. During the war it was only the working class's patriotism and unity that would save the British from Hitler. Orwell believed that sooner or later the working class would realize the futility of its situation, and, with the help of the lower-middle class, would claim power.

It soon became apparent that there would be no working-class revolution, which, in "The English People," written in 1944 but which did not appear until August 1947, Orwell said should not have been surprising since there had never been a revolutionary tradition in the working class. No matter the class, the British were too much alike. The lower-middle class had not adopted the socialist cause like Orwell had predicted. Militarism had simply never been a trait of the lower classes. He had underestimated part of the working class's character. "Individuals, too, are felt to conform to national pattern...Myths which are believed in tend to become true, because they set up a type, or 'persona', which the average person will do his best to resemble." ${ }^{211}$ Also, 
politicians had been a little more competent than he had projected. They had necessarily designed government policy according to the leftward sway in public opinion. The British economy had increasingly become a planned one. Orwell concluded that the working class had been tricked into complacency by the government.

Although class differences had been rapidly disintegrating during the war, especially in southern England where he believed the working and middle class would eventually merge, vast inequalities still existed between the classes by war's end. The growth of a popular media and the spread of luxury items into the working class were factors that Orwell had underestimated which had lessened class conflict. It was not as if class issues had been fully alleviated or that the British working class would never support democratic socialism. Orwell would never again call for a social revolution, but the myth of the northern British working class would continue to persist.

After the war, Orwell called for educational reforms that preserved northern British traditions. The distinctly working class culture in the north had remained largely in tact during the war. In northern industrial centers, the working class had kept free of bourgeois influence. In order to prevent northerners from being "branded on the tongue," Orwell suggested that one accent be taught in schools. ${ }^{212}$ Orwell did not want local accents to disappear; rather, he wanted northerners to have opportunities outside factories and mines. Orwell also insisted that schools should instill civic pride in children. Children were to learn about their local history and origins. "People ought to be proud of their own locality, they ought to feel 
that its scenery, its architecture and even its cookery are the best in the world. And such feelings, which do exist in some areas of the north but have lapsed throughout the greater part of England, would strengthen national unity rather than weaken it." ${ }^{213}$ Essays such as "In Defense of English Cooking" and "A Nice Cup of Tea" were attempts to bolster local and national pride.

Orwell believed that Britain's future rested on the preservation of northern British working-class culture. Only by exaggerating and sentimentalizing northern traditions did Orwell believe that he could reverse negative perceptions of the northern proletariat. Orwell truly considered the northern proletariat to be the natural heirs to power. He therefore created a moralized form of socialism based on what he perceived to be the working class's inherent characteristics. In doing so he not only had created a political myth, but had also formulated what is now known as Orwellian socialism. 


\section{NOTES}

${ }^{1}$ George Orwell, "Politics vs. Literature: An Examination of Gulliver's Travels," in The Penguin Essays of George Orwell (New York: Penguin Group, 1984), 380.

${ }^{2}$ Bernard Crick, George Orwell: A Life (Boston: Little, Brown and Company, 1980), 126.

${ }^{3}$ Richard Rees, George Orwell: Fugitive from the Camp of Victory (Carbondale: Southern Illinois University Press, 1962), 44.

${ }^{4}$ The New Encyclopedia Britannica, 15th ed., s.v. "Disraeli, Benjamin."

${ }^{5}$ P.P. Howe, preface to vol. 7 of The Complete Works of William Hazlitt, ed. P.P. Howe (London: J.M. Dent and Sons, Ltd., 1930), 17-9.

${ }^{6}$ William E. Laskowski, Jr., "George Orwell and the Tory-Radical Tradition," in The Revised Orwell, ed. Jonathan Rose (East Lansing: Michigan State Press, 1992), 150.

${ }^{7}$ George Orwell, "Charles Dickens," in The Penguin Essays of George Orwell (New York: Penguin Group, 1984), 38.

${ }^{8}$ Lionel Trilling, introduction to Homage to Catalonia by George Orwell (Boston: The Beacon Press, 1955), xiii.

${ }^{9}$ Ibid., XV.

${ }^{10}$ Ibid., xviii.

${ }^{11}$ George Orwell, "Such, Such Were the Joys," in The Penguin Essays of George Orwell (New York: Penguin Group, 1984), 451.

${ }^{12}$ Crick, George Orwell: A Life, 21.

${ }^{13}$ George Orwell, "Inside the Whale," in The Penguin Essays of George Orwell (New York: Penguin Group, 1984), 106. 152.

${ }^{14}$ Laskowski, Jr., "George Orwell and the Tory-Radical Tradition," 
${ }^{15}$ George Orwell, "The English people," in vol. 3 of The Collected Essays, Journalism and Letters of George Orwell, eds. Sonia Orwell and Ian Angus, (New York: Harcourt, Brace \& World, Inc., 1968), 29.

${ }^{16}$ George Orwell, "My Country Right or Left," in The Penguin Essays of George Orwell (New York: Penguin Group, 1984), 137.

${ }^{17}$ George Orwell, "The Lion and the Unicorn," in The Penguin Essays of George Orwell (New York: Penguin Group, 1984), 178.

${ }^{18}$ Crick, 16.

${ }^{19}$ bid., 27.

${ }^{20}$ Ibid., 22.

${ }^{21}$ Ibid., 47-75.

${ }^{22}$ lbid., 78.

${ }^{23}$ Alok Rai, Orwell and the Politics of Despair (New York: Cambridge University Press, 1988), 58.

${ }^{24}$ Crick, 100.

${ }^{25}$ Ibid., 101-02.

${ }^{26}$ David Wykes, A Preface to Orwell (New York: Longman Inc., 1987), 63.

${ }^{27}$ George Orwell, "Shooting an Elephant," in The Penguin Essays of George Orwell (New York: Penguin Group, 1984), 22.

${ }^{28}$ Wykes, A Preface to Orwell, 68.

${ }^{29}$ Crick, 187.

${ }^{30}$ Orwell, "The Lion and the Unicorn," 150.

${ }^{31}$ Ibid., 154.

${ }^{32}$ Richard Voorhees, The Paradox of George Orwell (West Lafayette, Purdue University Press, 1961), 96-7. 
${ }^{33}$ Crick, 15.

${ }^{34}$ Orwell, "The Lion and the Unicorn," 151.

${ }^{35}$ Ibid., 181.

${ }^{36}$ Alex Zwerdling, Onwell and the Left (New Haven: Yale University Press, 1974), 133.

${ }^{37}$ Voorhees, The Paradox of George Orwell, 92.

${ }^{38}$ Ibid., 94.

${ }^{39}$ Arthur M. Eckstein, "George Orwell's Secon Thoughts on

Capitalism," in The Revised Orwell, ed. Jonathan Rose (East Lansing:

Michigan State Press, 1992), 199-201.

${ }^{40}$ George Orwell, "Politics and the English Language," in The Penguin Essays of George Orwell (New York: Penguin Group, 1984), 356.

${ }^{41}$ Orwell, "The Lion and the Unicorn," 147.

${ }^{42}$ Zwerdling, Orwell and the Left, 6.

${ }^{43}$ Ibid., 86.

${ }^{44}$ Ibid., 130.

${ }^{45}$ William Steinhoff, George Orwell and the Origins of 1984 (Ann Arbor: The University of Michigan Press, 1975), 61.

${ }^{46}$ George Orwell, "Inside the Whale," in The Penguin Essays of George Orwell (New York: Penguin Group, 1984), 120.

${ }^{47}$ Rai, Orwell and the Politics of Despair, 105.

${ }^{48}$ John Rodden, "On the Political Sociology of Intellectuals: George Orwell and the London Left Intelligentsia," in The Revised Orwell, ed. Jonathan Rose (East Lansing: Michigan State Press, 1992), 210.

${ }^{49}$ Ibid., 212.

${ }^{50}$ Orwell, "Inside the Whale," 122. 
${ }^{51}$ Steinhoff, George Orwell and the Origins of 1984, 68.

${ }^{52}$ Rees, George Orwell: Fugitive from the Camp of Victory, 46.

${ }^{53}$ George Orwell, "Antisemitism in Brittain," The Penguin Essays of George Orwell (New York: Penguin Group, 1984), 284.

${ }^{54}$ George Orwell, "Notes on Nationalism," in The Penguin Essays of George Orwell (New York: Penguin Group, 1984), 313.

${ }^{55}$ George Orwell, "Notes on Nationalism," in The Penguin Essays of George Orwell (New York: Penguin Group, 1984), 303-4.

${ }^{56}$ Steinhoff, 90.

${ }^{57}$ Orwell, "The Lion and the Unicorn," 169.

${ }^{58}$ Steinhoff, 92.

${ }^{59}$ Orwell, "Notes on Nationalism," 312.

${ }^{60}$ Wykes, 171.

${ }^{61}$ Rees, 61.

${ }^{62}$ Orwell, "Politics vs Literature: An Examination of Gulliver's Travels," 379.

${ }^{63}$ Zwerdling, 18.

${ }^{64}$ George Orwell, "Wells, Hitler and the World State," in The Penguin Essays of George Orwell (New York: Penguin Group, 1984), 191.

${ }^{65}$ Ibid., 191-2.

${ }^{66}$ Zwerdling, 35.

${ }^{67}$ Orwell, "The Lion and the Unicorn," 171.

${ }^{68}$ Ibid., 172-3.

${ }^{69}$ Orwell, "The English People," 14. 
${ }^{70}$ Stanley Pierson, British Socialists: The Journey from Fantasy to Politics (Cambridge: Harvard University Press, 1979), 339.

${ }^{71}$ Ibid., 343-4.

${ }^{72}$ Orwell, "The Lion and the Unicorn," 174-5.

${ }^{73}$ Ibid., 175-6.

${ }^{74}$ Rees, 55.

${ }^{75}$ Orwell, "The English People," 6.

${ }^{76}$ Ibid., 14-5.

${ }^{77}$ Wykes, 96-7.

${ }^{78}$ Orwell, "The English People," 7.

${ }^{79}$ Wykes, 94.

${ }^{80}$ Orwel, "Inside the Whale," 125.

${ }^{81}$ Steinhoff, 44-5.

${ }^{82}$ George Orwell, "Second Thoughts on James Burnham," in Shooting an Elephant (New York: Harcourt, Brace and Company, 1950), 123.

${ }^{83}$ Zwerdling, 102.

${ }^{84}$ Orwell, "Second Thoughts on James Burnham," 145.

${ }^{85}$ George Orwell, "My Country Right or Left," in The Penguin Essays of George Orwell (New York: Penguin Group, 1989), 137.

${ }^{86}$ Orwell, "The English People," 15.

${ }^{87}$ Ibid., 31.

${ }^{88}$ Ibid., 32.

${ }^{89}$ Ibid., 34. 
${ }^{90}$ Ibid., 35.

${ }^{91}$ Ibid., 37.

${ }^{92}$ Wykes, 95.

${ }^{93}$ Wolf Lepenies, Between Literature and Science: The Rise of

Sociology, trans. R.J. Hollingdale (Cambridge University Press, 1988), 194.

${ }^{94}$ Ibid., 99.

${ }^{95}$ Ibid., 103.

${ }^{96}$ Ibid., 124.

${ }^{97}$ Ibid., 137.

${ }^{98}$ Ibid., 144.

${ }^{99}$ Ibid., 151.

${ }^{100}$ George Orwell, Down and Out in Paris and London (New York: Harcourt, Brace and Company, 1933; repr., New York: The Berkley Publishing Company, 1961), 52.
${ }^{101}$ Ibid., 87.
${ }^{102}$ Ibid., 38.
${ }^{103}$ Ibid., 48.
${ }^{104}$ Ibid., 102.
${ }^{105}$ Ibid., 147.
${ }^{106}$ Ibid., 111.
${ }^{107}$ ibid., 150.
108 ibid., 154. 
${ }^{109}$ George Orwell, Burmese Days, in The Penguin Complete Novels of George Orwell (Great Britain: Victor Gollancz, 1935; repr., New York: Penguin Group, 1983), 222.

${ }^{110}$ lbid., 135.

${ }^{111}$ George Orwell, A Clergyman's Daughter, in The Penguin Complete Novels of George Orwell (Great Britain: Victor Gollanz, 1935; repr., New York: Penguin Group, 1983), 424-5.

${ }^{112}$ Ibid., 265.

${ }^{113}$ Ibid., 285.

${ }^{114}$ Ibid., 413.

${ }^{115}$ George Orwell, Keep the Aspidistra Flying, in The Penguin Complete Novels of George Orwell (Great Britain: Victor Gollanz, 1936; repr., New York: Penguin Group, 1983), 595.

${ }^{116}$ lbid., 631.

${ }^{117}$ Ibid., 583.

${ }^{118}$ Ibid., 624-5

${ }^{119}$ Ibid., 632.

${ }^{120}$ Ibid., 713.

${ }^{121}$ George Orwell, The Road to Wigan Pier, with a forward by Victor Gollancz (New York: Harcourt, Brace and Company, 1958), 158.

${ }^{122}$ Ibid., 170-1.

${ }^{123}$ lbid., 209.

${ }^{124}$ Ibid., 208-9.

${ }^{125}$ Ibid., 262-3.

${ }^{126}$ Ibid., 259. 
${ }^{127}$ Ibid., 263.

${ }^{128}$ Ibid., 220.

${ }^{129}$ Ibid., 229.

${ }^{130}$ Ibid., 226.

${ }^{131}$ Ibid., 236.

${ }^{132}$ Ibid., 18.

${ }^{133}$ Ibid., 46.

${ }^{134}$ Ibid., 142.

${ }^{135}$ Ibid., 184.

${ }^{136}$ Ibid., 146.

${ }^{137}$ George Orwell, Homage to Catalonia, with an Introduction by Lionel Trilling (Boston: The Beacon Press, 1952), 50.

${ }^{138}$ Ibid., 6.

${ }^{139}$ Ibid., 9.

${ }^{140}$ Ibid., 28.

${ }^{141}$ Ibid., 12.

${ }^{142}$ Ibid., 23.

${ }^{143}$ Ibid., 127.

${ }^{144}$ Ibid., 224.

${ }^{145}$ Ibid., 223.

${ }^{146}$ Ibid., 203.

${ }^{147}$ Ibid., 145. 
${ }^{148}$ Ibid., 167.

${ }^{149}$ Ibid., 170.

${ }^{150}$ Ibid., 60.

${ }^{151}$ Ibid., 61.

${ }^{152}$ lbid., 81.

${ }^{153}$ Ibid., 59.

${ }^{154}$ Ibid., 68.

${ }^{155}$ Ibid., 56.

${ }^{156}$ George Orwell, Coming Up for Air, in The Penguin Complete Novels of George Orwell (Great Britain: Victor Gollanz, 1939; repr., New York: Penguin Group, 1983), 455.

${ }^{157}$ Ibid., 447.

${ }^{158}$ Ibid., 493.

${ }^{159}$ Ibid., 454.

${ }^{160}$ Ibid., 503.

${ }^{161}$ Ibid., 517-9.

${ }^{162}$ Ibid., 462.

${ }^{163}$ Ibid., 468.

${ }^{164}$ Ibid., 437.

${ }^{165}$ Ibid., 565.

${ }^{166}$ Zwerdling, 193.

${ }^{167}$ George Orwell, Animal Farm, in The Penguin Complete Novels of George Orwell (Great Britain: Martin Secker \& Warburg Ltd., 1945; repr., New York: Penguin Group, 1983), 33. 
${ }^{168}$ Ibid., 19.

${ }^{169}$ Ibid., 42.

${ }^{170}$ Ibid., 47.

${ }^{171}$ lbid., 47-8.

${ }^{172}$ George Orwell, Nineteen Eighty-Four, in The Penguin Complete Novels of George Orwell (Great Britain: Martin Secker \& Warburg Ltd., 1949; repr., New York: Penguin Group, 1983), 886.

${ }^{173}$ Ibid., 842.

${ }^{174}$ Ibid., 835.

${ }^{175}$ Ibid., 860

${ }^{176}$ Ibid., 784-5

177 lbid., 867.

${ }^{178}$ Ibid., 868.

${ }^{179}$ Ibid., 861-2.

${ }^{180}$ Ibid., 681.

${ }^{181}$ Ibid., 863.

${ }^{182}$ Ibid., 777-8.

${ }^{183}$ Ibid., 786.

${ }^{184}$ Mircea Eliade, Cosmos and History: The Myth of the Eternal Return, trans. Willard R. Trask (New York: Harper \& Row, Publishers, 1959), 28.

${ }^{185}$ Ibid., 52.

${ }^{186}$ Ibid., 81.

${ }^{187}$ Ibid., 74. 
${ }^{188}$ Ibid., 105.

${ }^{189}$ Ibid., 43.

${ }^{190}$ Ian G. Barbour, Myths, Models and Paradigms: A Comparative Study in Science and Religion (New York: Harper \& Row, Publishers, 1974), 171.

${ }^{191}$ Ibid., 181.

${ }^{192}$ Ibid., 20-1.

${ }^{193}$ Zwerdling, 57.

${ }^{194}$ George Orwell, "As I Please," Tribune, December 1943, in vol. 3 of The Collected Essays, Journalism and Letters of George Orwell, eds. Sonia Orwell and lan Angus (New York: Harcourt, Brace \& World, Inc., 1968), 64.

${ }^{195}$ Zwerdling, $57-8$.

${ }^{196} \mathrm{H}$. Stuart Hughes, Consciousness and Society: The Reorientation of European Social Thought, 1890-1930 (New York: Vintage Books, 1958), 171.

${ }^{197}$ Georges Sorel, Reflections on Violence, trans. T.E. Hulme and J. Roth, with an Introduction by Edward A. Shils (Glencoe, III.: The Free Press, 1950), 261.

${ }^{198}$ Hughes, Consciousness and Society: The Reorientation of European Social Thought, 1890-1930, 170.

${ }^{199}$ Lesjek Kolakowski, Main Currents of Marxism: Its Origins, Growth and Dissolution, trans. P.5. Falla (Oxford: Oxford University Press, 1978), 168.

${ }^{200}$ Ibid., 158.

${ }^{201}$ Ibid., 161 .

${ }^{202}$ Sorel, Reflections on Violence, $570-8$.

${ }^{203}$ Ibid., 201. 
${ }^{204}$ Orwell, "Second Thoughts on James Burnham," 123.

${ }^{205}$ Zwerdling, 152.

${ }^{206}$ Ibid., 176.

${ }^{207}$ ibid., 181.

${ }^{208}$ George Orwell, "As I Please," Tribune, 1945, in vol. 3 of The Collected Essays, Journalism and Letters of George Orwell, eds. Sonia Orwell and lan Angus (New York: Harcourt, Brace \& World, Inc., 1968), 405-6.

${ }^{209}$ Zwerdling, 196.

${ }^{210}$ Orwell, "The Lion and the Unicorn," 175.

${ }^{211}$ Orwell, "The English People," 6.

${ }^{212}$ lbid., 34.

${ }^{213}$ lbid., 35. 


\section{WORKS CITED}

Barbour, lan G. Myths, Models and Paradigms: A Comparative Study in Science and Religion. New York: Harper \& Row, Publisher, 1974.

Carlyle, Thomas. The French Revolution. New York: A.L. Burt Company, Publishers, 1900.

Crick, Bernard. George Orwell: A Life. Boston: Little, Brown and Company, 1980.

Dickens, Charles. Hard Times. With an Afterword by Charles Shapiro. New York: The New American Library, Inc., 1980.

Eckstein, Arthur M. "George Orwell's Second Thoughts on Capitalism." In The Revised Orwell, ed. Johnathan Rose. East Lansing: Michigan State Press, 1992.

Eliade, Mircea. Cosmos and History: The Myth of the Eternal Return. Translated by Willard R. Trask. New York: Harper \& Row, Publishers, 1959.

Howe, P.P. Preface to vol. 7 of The Complete Works of William Hazlitt. Edited by P.P. Howe. London: J.M. Dent and Sons, Ltd., 1930.

Hughes, H. Stuart. Consciousness and Society: The Reorientation of European Social Thought, 1890-1930. New York: Vintage Books, 1958.

Ingle, Stephen. George Orwell: A Political Life. New York: St. Martin's Press, 1993.

Kolakowski, Lesjek. Main Currents of Marxism: Its Origins, Growth and Dissolution. Translated by P.S. Falla. Oxford: Oxford University Press, 1978.

Laskowski, Jr. William E. "George Orwell and the Tory-Radical Tradition." In The Revised Orwell, ed. Johnathan Rose. East Lansing:

Michigan State Press, 1992. 
Lee, Robert A. Orwell's Fiction. South Bend: University of Notre Dame Press, 1969.

Lepenies, Wolf. Between Literature and Science: The Rise of Sociology. Translated by R. J.Hollingdale. Cambridge: Cambridge University Press, 1988.

Macdonald, J. Ramsay. Syndicalism: A Critical Examination. Chicago: The Open Court Publishing Company, 1912.

Nelson, John S. "Orwell's Political Myths and Ours." In The Orwellian Moment, eds. Robert L.Savage, James Combs and Dan Nimmo. Fayetteville: The University of Arkansas Press, 1989.

Orwell, George. Vol. 3 of The Collected Essays, Journalism and Letters of George Orwell. Edited by Sonia Orwell and Ian Angus. New York: Hancourt, Brace \& World, Inc., 1968.

. Down and Out in Paris and London. New York: Harcourt, Brace and Company, 1933; repr., New York: The Berkley Publishing Company, 1961.

. Homage to Catalonia. With an Introduction by Lionel Trilling.

Boston: The Beacon Press, 1952.

. The Penguin Essays of George Orwell. New York: Penguin Group, 1984.

Shooting an Elephant. New York: Harcourt, Brace and Company, 1950.

. The Road to Wigan Pier. With a Forward by Victor Gollancz. New York: Harcourt, Brace and Company, 1958.

Pierson, Stanley. British Socialists: The Journey from Fantasy to Politics. Cambridge: Harvard Unviersity Press, 1979.

Pocock, J.G.A. The Machiavellian Moment: Florentine Political Thought and the Atlantic Republican Tradition. Princeton: Princeton University Press, 1975.

Rai, Alok. Orwell and the Politics of Despair. New York: Cambridge University Press, 1988. 
Rees, Richard. George Orwell: Fugitive from the Camp of Victory.

Carbondale: Southern Illinois University Press, 1962.

Rodden, John. "On the Political Sociology of Intellectuals: George Orwell and the London Left Intelligentsia." In The Revised Orwell, ed. Johnathan Rose. East Lansing: Michigan State Press, 1992.

Sheldon, Michael. Orwell: The Authorized Biography. New York: HarperCollins Publishers, Inc., 1992.

Smith, Henry Nash. Virgin Land: The American West as Symbol and Myth. Cambridge: Harvard Unversity Press, 1950.

Sorel, Georges. Reflections on Violence. Translated by T.E. Hulme and J. Roth, with an Introduction by Edward A. Sails. Glencoe, III.: The Free Press, 1950.

Steinhoff, William. George Orwell and the Origins of 1984. Ann Arbor: The Unversity of Michigan Press, 1975.

The Encyclopaedia Britannica, 15th ed. s.v. "Disraeli, Benjamin."

Trilling, Lionel. Introduction to Homage to Catalonia, by George Orwell. Boston: The Beacon Press, 1955.

Voorhees, Richard. The Paradox of George Orwell. West Lafayette: Purdue University Press, 1961.

Wells, H.G. The New World Order. New York: Alfred A. Knopf, 1940.

- A Modern Utopia. With an Introduction by Mark R. Hillegas. Lincoln: University of Nebraska Press, 1967.

Whitman, Walt. Complete Poetry and Collected Prose. New York:

Literary Classics of the United States, Inc., 1982.

Woodcock, George. Orwell's Message: 1984 and the Present. Madeira Parbe, BC: Harbour Publishing Co. Ltd., 1984.

Wykes, David. A Preface to Orwell. New York: Longman Inc., 1984.

Zwerdling, Alex. Orwell and the Left. New Haven: Yale University Press, 1974. 